\title{
NEXT GENERATION ENGINEERED MATERIALS FOR ULTRA SUPERCRITICAL STEAM TURBINES
}

\author{
FINAL TECHNICAL REPORT
}

September 2003 to May 2006

Report Issued June 2006

under

U.S Department of Energy

Cooperative Agreement No. DE-FC26-04NT42232

\author{
Dr. Douglas Arrell \\ Siemens Power Generation, Inc. \\ 4400 Alafaya Trail \\ Orlando, FL 32826
}

\begin{abstract}
Additional contributions from
Anita Balik, Allister James, Dr. Anand Kulkarni \& Dr. Monica Maris-Jakobowski Siemens Power Generation, Inc. 4400 Alafaya Trail

Orlando, FL 32826

Professor Carl Koch

North Carolina State University

03 Holladay Hall

Campus Box 7003

Raleigh, NC 27695
\end{abstract}




\section{DISCLAIMER}

"This report was prepared as an account of work sponsored by an agency of the United States Government. Neither the United States Government nor any agency thereof, nor any of their employees, make any warranty, express or implied, or assume any legal liability or responsibility for the accuracy, completeness, or usefulness of any information, apparatus, product, or process disclosed, or represents that its use would not infringe privately owned rights. Reference herein to any specific commercial product, process, or service by trade name, trademark, manufacturer, or otherwise does not necessarily constitute or imply its endorsement, recommendation, or favoring by the United States Government or any agency thereof. The views and opinions of authors expressed herein do not necessarily state or reflect those of the United States Government or any agency thereof." 


\section{ABSTRACT}

To reduce the effect of global warming on our climate, the levels of $\mathrm{CO}_{2}$ emissions should be reduced. One way to do this is to increase the efficiency of electricity production from fossil fuels. This will in turn reduce the amount of $\mathrm{CO}_{2}$ emissions for a given power output. Using US practice for efficiency calculations, then a move from a typical US plant running at $37 \%$ efficiency to a $760^{\circ} \mathrm{C} / 38.5 \mathrm{MPa}\left(1400^{\circ} \mathrm{F} / 5580 \mathrm{psi}\right)$ plant running at $48 \%$ efficiency would reduce $\mathrm{CO}_{2}$ emissions by $170 \mathrm{~kg} / \mathrm{MW}$.hr or $25 \%$.

This report presents a literature review and roadmap for the materials development required to produce a $760^{\circ} \mathrm{C}\left(1400^{\circ} \mathrm{F}\right) / 38.5 \mathrm{MPa}(5580 \mathrm{psi})$ steam turbine without use of cooling steam to reduce the material temperature.

The report reviews the materials solutions available for operation in components exposed to temperatures in the range of 600 to $760^{\circ} \mathrm{C}$, i.e. above the current range of operating conditions for today's turbines. A roadmap of the timescale and approximate cost for carrying out the required development is also included.

The nano-structured austenitic alloy CF8C+ was investigated during the program, and the mechanical behavior of this alloy is presented and discussed as an illustration of the potential benefits available from nano-control of the material structure. 


\section{EXECUTIVE SUMMARY}

To reduce the effect of global warming on our climate, the levels of $\mathrm{CO}_{2}$ emissions should be reduced. One way to do this is to increase the efficiency of electricity production from fossil fuels. This will in turn reduce the amount of $\mathrm{CO}_{2}$ emissions for a given power output. Using US practice for efficiency calculations, then a move from a typical US plant running at $37 \%$ efficiency to a $760^{\circ} \mathrm{C} / 38.5 \mathrm{MPa}\left(1400^{\circ} \mathrm{F} / 5580 \mathrm{psi}\right)$ plant running at $48 \%$ efficiency would reduce $\mathrm{CO}_{2}$ emissions by $170 \mathrm{~kg} / \mathrm{MW}$.hr or $25 \%$.

This report presents a literature review and roadmap for the materials development required to produce a $760^{\circ} \mathrm{C}\left(1400^{\circ} \mathrm{F}\right) / 38.5 \mathrm{MPa}(5580 \mathrm{psi})$ steam turbine without use of cooling steam to reduce the material temperature, as well as results from trials on the nano-strengthened austenitic alloy CF8C+.

The report reviews the materials solutions available for operation in components exposed to temperatures in the range of 600 to $760^{\circ} \mathrm{C}$, i.e. above the current range of operating conditions for today's turbines. A roadmap of the timescale and approximate cost for carrying out the required development is also included.

To allow the design of $760^{\circ} \mathrm{C}$ capable steam turbines without component cooling, a very large leap in material capability is required. Ferritic materials are unlikely to be suitable for temperatures beyond $650^{\circ} \mathrm{C}$ within the foreseeable future. The new generation of nano-strengthened alloys provide a significant improvement in strength beyond that of traditional tempered martensitic steels, but suffer from significant drawbacks when used at higher temperatures. The $12 \% \mathrm{Cr}$ steels currently available have excellent creep resistance, but do not appear to be stable for long periods of exposure. $9 \% \mathrm{Cr}$ steels may address this problem, but need oxidation coatings. In the short term, nickel-based superalloys will be needed.

The work carried out on the CF8C+ alloy shows significant improvements in terms of creep capability. This demonstrates that the potential does exist to push steels to higher temperatures, possibly with the help of oxidation coatings. However, due to the stability questions mentioned above, extensive long term testing of such alloys will be required before they can be implemented.

For blading, current gas turbine alloys will be suitable. With advanced processing, current turbine disk materials will probably be suitable for the first stage of the rotor. For stages further back, large forgings are likely to be realistic. The rotor will have to be a composite structure, probably welded, to reduce the cost to a reasonable level.

Erosion-resistant coatings suitable for the highest temperatures have not been tested, but compositions are available which are likely to be suitable for the application. Testing of these coating sis currently being funded by the DOE in another program.

The largest issue will be with the cast components such as casings and valve bodies. Current superalloys have sufficient strength, but have not been cast in such large sizes under sand-cast conditions. Roadmaps of the expected development time are provided, which indicated that the materials required can be available within a 5 year time span, i.e. 2011 at the time of writing. 


\section{TABLE OF CONTENTS}

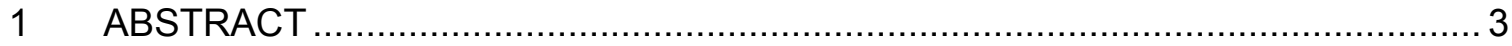

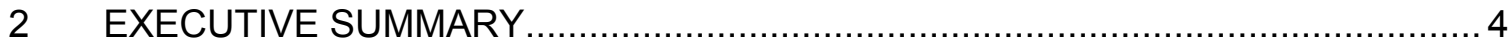

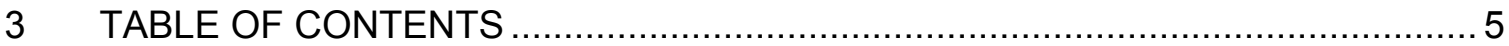

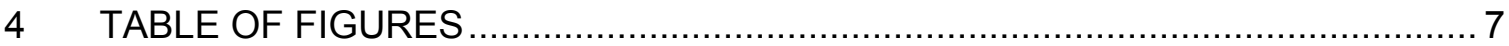

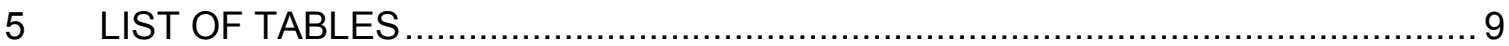

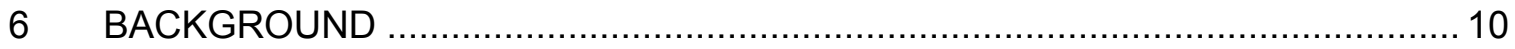

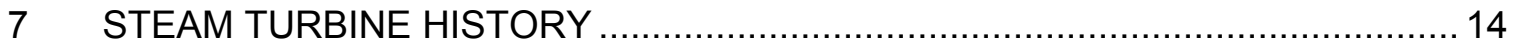

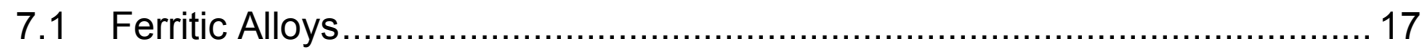

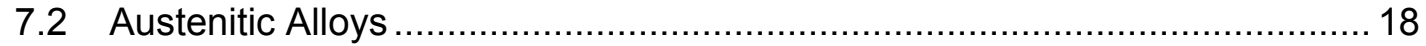

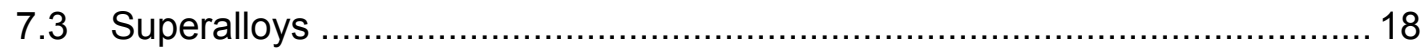

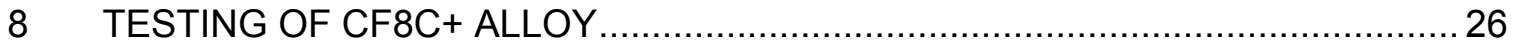

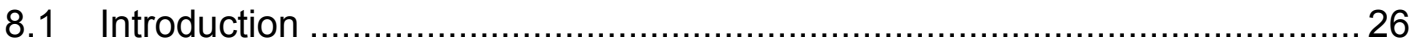

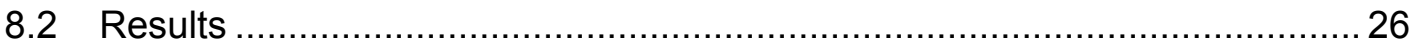

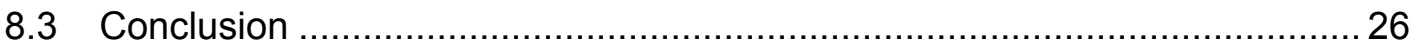

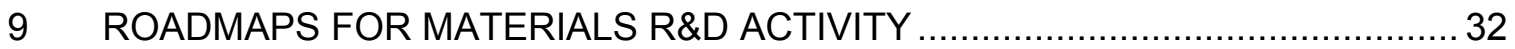

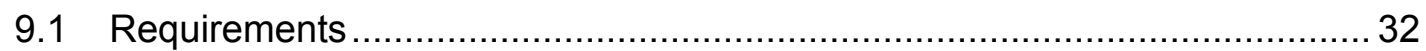

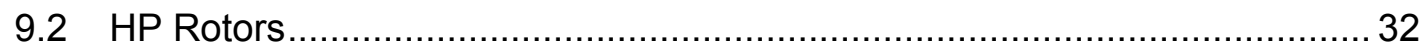

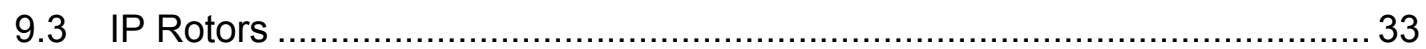

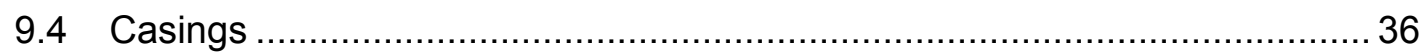

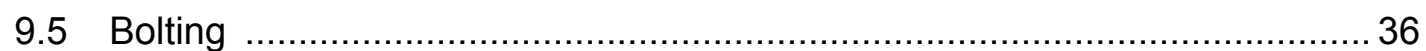

10 SUMMARY OF FUTURE TURBINE USING ROADMAP MATERIALS

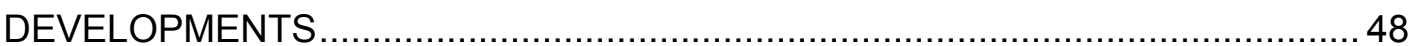

11 APPENDICES: MATERIALS TECHNOLOGY NARRATIVES ..............................50

11.1 Rotor materials - advanced processing of current alloys .............................5 50

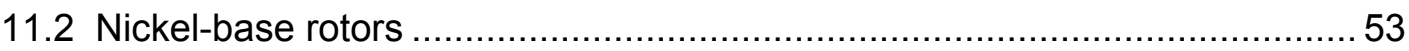

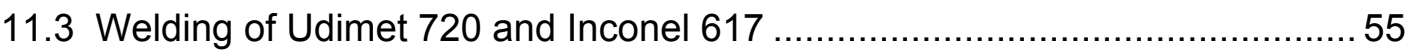

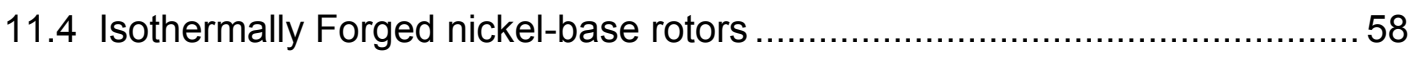

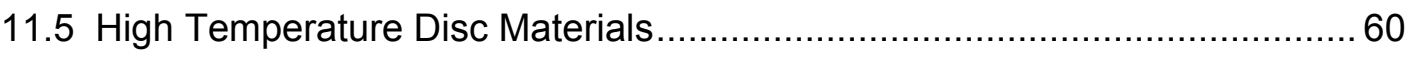

11.6 Rotor blade materials - advanced processing of current alloys................... 65

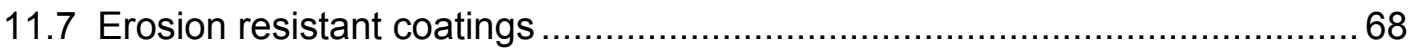

11.8 Casing materials / large scale nickel castings ............................................ 71

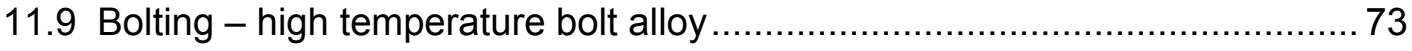

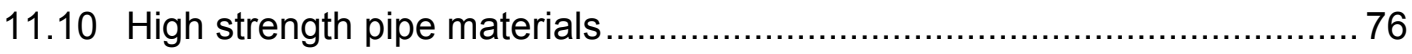


11.11 Auxiliary \& Casing materials manufacture - welding development for

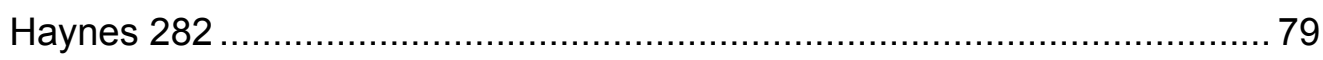

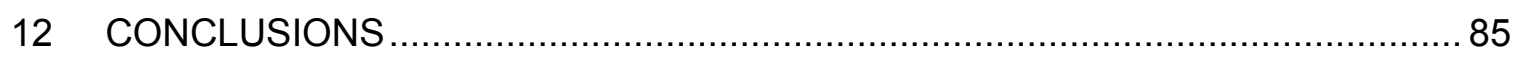

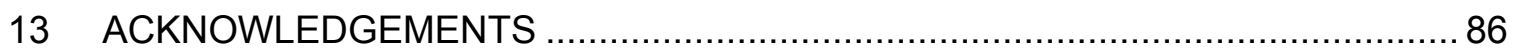

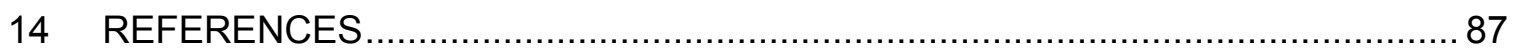




\section{TABLE OF FIGURES}

Figure 1. Carbon Dioxide Emissions vs. Net Plant Efficiency (G. Booras, EPRI). 13

Figure 2. History of steam turbine material development programs (F. Masuyama, Kyushu Institute of Technology).

Figure 3. Operating temperature of sample steam turbines over the last 50 years 15

Figure 4. Comparison of the development of turbine operating temperatures within 4 major markets 15

Figure 5. Uncooled Siemens $600^{\circ} \mathrm{C} / 300$ bar $\left(1112^{\circ} \mathrm{F} / 4350\right.$ psi) HP turbine module .... 16

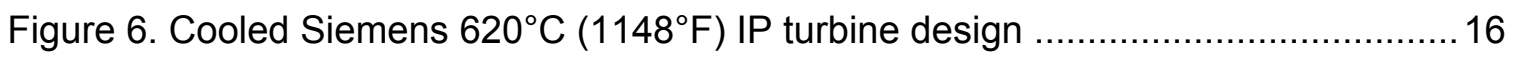

Figure 7 . Size of a selection of powerplants built over the last 50 years ..................... 17

Figure 8. Stress vs. rupture life for Grade 91 showing the original extrapolation $(C=32)$

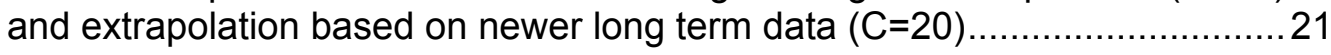

Figure 9. Rupture strength of P92 and related alloys........................................... 21

Figure 10. Loss of creep strength at 30,000 hrs in TAF650 steel ............................. 22

Figure 11. Creep strength in 3 9-12\% Cr steels. X19 forms Z phase, the other two do not..

Figure 12. European COST steel development programs and the expected usability temperatures (in $\left.{ }^{\circ} \mathrm{C}\right)^{6}$

Figure 13. Promising compositions from the COST 522 program .... 23

Figure 14. Post-P92 steels developed in Japan ${ }^{3}$ 24

Figure 15. Effect of boron nitride precipitation in ferritic steels ${ }^{3}$ 24

Figure 16. Summary of literature values for 100 000h creep strength of ferritic rotor steels

Figure 17. LCF comparison between $347 \mathrm{SS}$ and CF8C+..... 28

Figure 18. $0.2 \%$ Yield stress comparison for the two alloys. On a like-for-like basis, the CF8C+ outperforms 347SS.

Figure 19. Ultimate tensile stress comparison for the two alloys. On a like-for-like basis, the CF8C+ outperforms 347SS.

Figure 20. Larson Miller creep comparison for the two alloys. On a like-for-like basis, the CF8C+ outperforms 347SS.

Figure 21. Roadmap for High Pressure Rotor Materials 
Figure 22. Schematic of alloy weldability against aluminum and titanium levels in the parent alloy showing the difficulty of welding IN 100 .

Figure 23. Roadmap for Intermediate Pressure Rotor Materials .............................. 43

Figure 24. Roadmap for first stage turbine blade alloys (HP and IP) .........................44

Figure 25. Roadmap for first stage turbine vane alloys (HP and IP) .........................45

Figure 26. Roadmap of erosion and steam resistant coating development ..................46

Figure 27. Roadmap for high temperature casing materials ................................ 47

Figure $28.600^{\circ} \mathrm{C}$ steam turbine materials selections .......................................... 48

Figure 29. Possible $760^{\circ} \mathrm{C}$ steam turbine materials selections ................................49

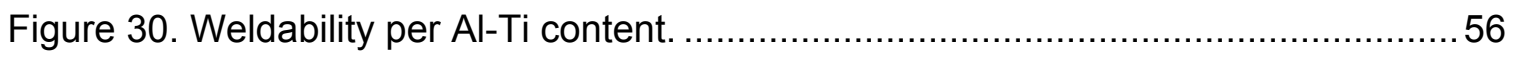

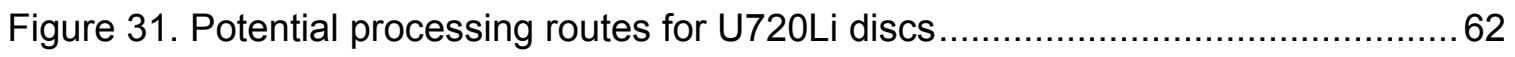

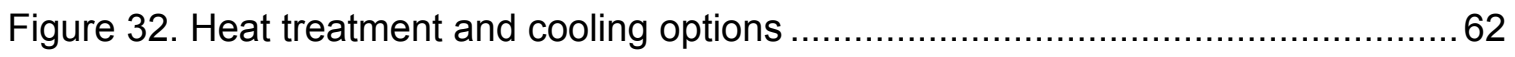

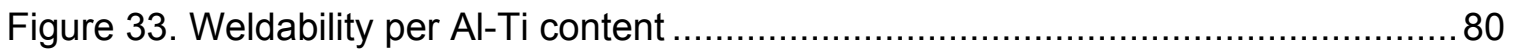




\section{LIST OF TABLES}

Table 1. Estimated Plant Efficiencies for Various Steam Cycles (P. Weitzel, B\&W and M.

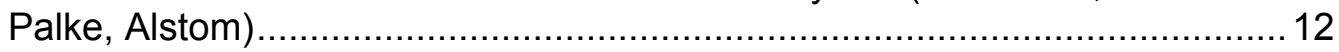

Table 2. Selected potential candidate alloys for USC steam turbine operation .............20

Table 3. Composition and compositional specifications for the $347 \mathrm{SS}$ and CF8C+ heats

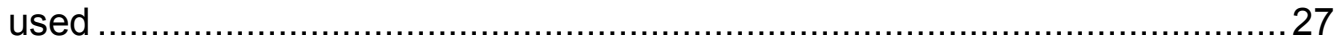

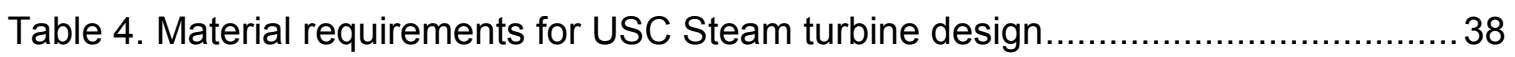

Table 5. Composition of high temperature wrought alloys ......................................... 73

Table 6. Stress to produce rupture, based in literature data $\left(871^{\circ} \mathrm{C}\left(1600^{\circ} \mathrm{F}\right)\right.$ and 1000

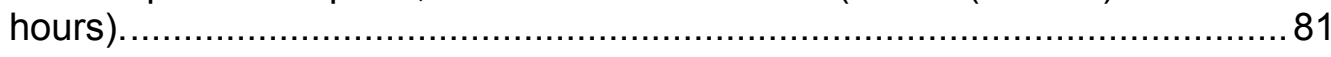

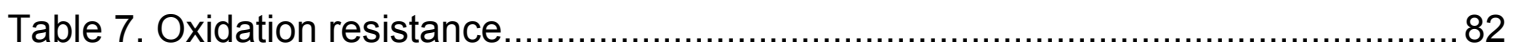

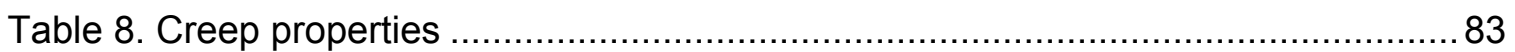




\section{BACKGROUND}

To reduce the effect of global warming on our climate, the levels of $\mathrm{CO}_{2}$ emissions should be reduced. One way to do this is to increase the efficiency of electricity production from fossil fuels. This will in turn reduce the amount of $\mathrm{CO}_{2}$ emissions for a given power output. Typical efficiencies for today's and future turbine designs are shown in. Using US practice for efficiency calculations, then a move from a typical US plant running at $37 \%$ efficiency to a $760^{\circ} \mathrm{C} / 38.5 \mathrm{MPa}\left(1400^{\circ} \mathrm{F} / 5580 \mathrm{psi}\right)$ plant running at $48 \%$ efficiency would reduce $\mathrm{CO}_{2}$ emissions by $170 \mathrm{~kg} / \mathrm{MW}$.hr or $25 \%$ (Figure 1 ).

This report presents a literature review and roadmap for the materials development required to produce a $760^{\circ} \mathrm{C}\left(1400^{\circ} \mathrm{F}\right) / 38.5 \mathrm{MPa}(5580 \mathrm{psi})$ steam turbine without use of cooling steam to reduce the material temperature.

To provide materials to raise the efficiency of steam turbine operation, a number of projects have run in various countries. The two major projects (Figure 2 ) being a Japanese one for $650^{\circ} \mathrm{C}\left(1202^{\circ} \mathrm{F}\right)$ materials, and a $700^{\circ} \mathrm{C}\left(1292^{\circ} \mathrm{F}\right)$ project known as AD700 or Thermie run in Europe. The DOE program is the most ambitious ( 
Table 1), and builds on the information published in the literature on the other two programs. This report will detail the technologies, both in terms of metallurgical improvement and process improvement needed to develop a $760^{\circ} \mathrm{C}$ turbine. 
Table 1. Estimated Plant Efficiencies for Various Steam Cycles (P. Weitzel, B\&W and M. Palke, Alstom)

\begin{tabular}{|c|c|c|c|}
\hline Description & Cycle & $\begin{array}{l}\text { Reported at } \\
\text { European } \\
\text { Location } \\
\text { (LHV/HHV) }\end{array}$ & $\begin{array}{l}\text { Converted } \\
\text { to US } \\
\text { Practice }^{(2)}\end{array}$ \\
\hline Subcritical & 16.8 $\mathrm{MPa} / 538^{\circ} \mathrm{C} / 538^{\circ} \mathrm{C}$ & & 37 \\
\hline Supercritical & $24.5 \mathrm{MPa} / 565^{\circ} \mathrm{C} / 565^{\circ} \mathrm{C} / 565^{\circ} \mathrm{C}^{(1)}$ & & \\
\hline $\begin{array}{l}\text { ELSAM } \\
\text { (Nordjyland 3) }\end{array}$ & $28.9 \mathrm{MPa} / 580^{\circ} \mathrm{C} / 580^{\circ} \mathrm{C} / 580^{\circ} \mathrm{C}$ & $47 / 44$ & 40.9 \\
\hline $\begin{array}{l}\text { State of the Art } \\
\text { Supercritical (LEBS) }\end{array}$ & $31.5 \mathrm{MPa} / 595^{\circ} \mathrm{C} / 593^{\circ} \mathrm{C} / 593^{\circ} \mathrm{C}^{(1)}$ & & 42 \\
\hline Thermie & $38 \mathrm{MPa} / 700^{\circ} \mathrm{C} / 720^{\circ} \mathrm{C} / 720^{\circ} \mathrm{C}$ & $50.2 / 47.7$ & $46 / 43$ \\
\hline EPRI/Parson & $37.8 \mathrm{MPa} / 700^{\circ} \mathrm{C} / 700^{\circ} \mathrm{C} / 700^{\circ} \mathrm{C}$ & & 44 \\
\hline $\begin{array}{l}\text { DOE/OCDO USC } \\
\text { Project }\end{array}$ & $\begin{array}{l}38.5 \mathrm{MPa} / 760^{\circ} \mathrm{C} / 760^{\circ} \mathrm{C} \\
38.5 \mathrm{MPa} / 760^{\circ} \mathrm{C} / 760^{\circ} \mathrm{C} / 760^{\circ} \mathrm{C}\end{array}$ & & $\begin{array}{l}46.5 \\
47.5-48\end{array}$ \\
\hline \multicolumn{4}{|c|}{$\begin{array}{l}\text { Eastern bituminous Ohio coal. Lower Heating value, LHV, boiler fuel efficiency is higher than higher heating value, HHV } \\
\text { boiler fuel efficiency. For example, an LHV net plant heat rate at } 6205.27 \text { Btu/kWh with the LHV net plat efficiency of } 55 \\
\text { compares to the HHV net plant heat rate ay } 6494 \text { Btu/kWh and HHV net plant efficiency of } 52.55 \% \\
\text { Reported European efficiencies are generally higher compared to U.S. due to differences in reporting practice (LHV vs } \\
\text { HHV), coal quality, auxiliary power needs, condenser pressure and ambient temperature and many other variables. } \\
\text { Numbers in this column for European project numbers are adjusted for U.S. conditions to facilitate comparison. }\end{array}$} \\
\hline
\end{tabular}




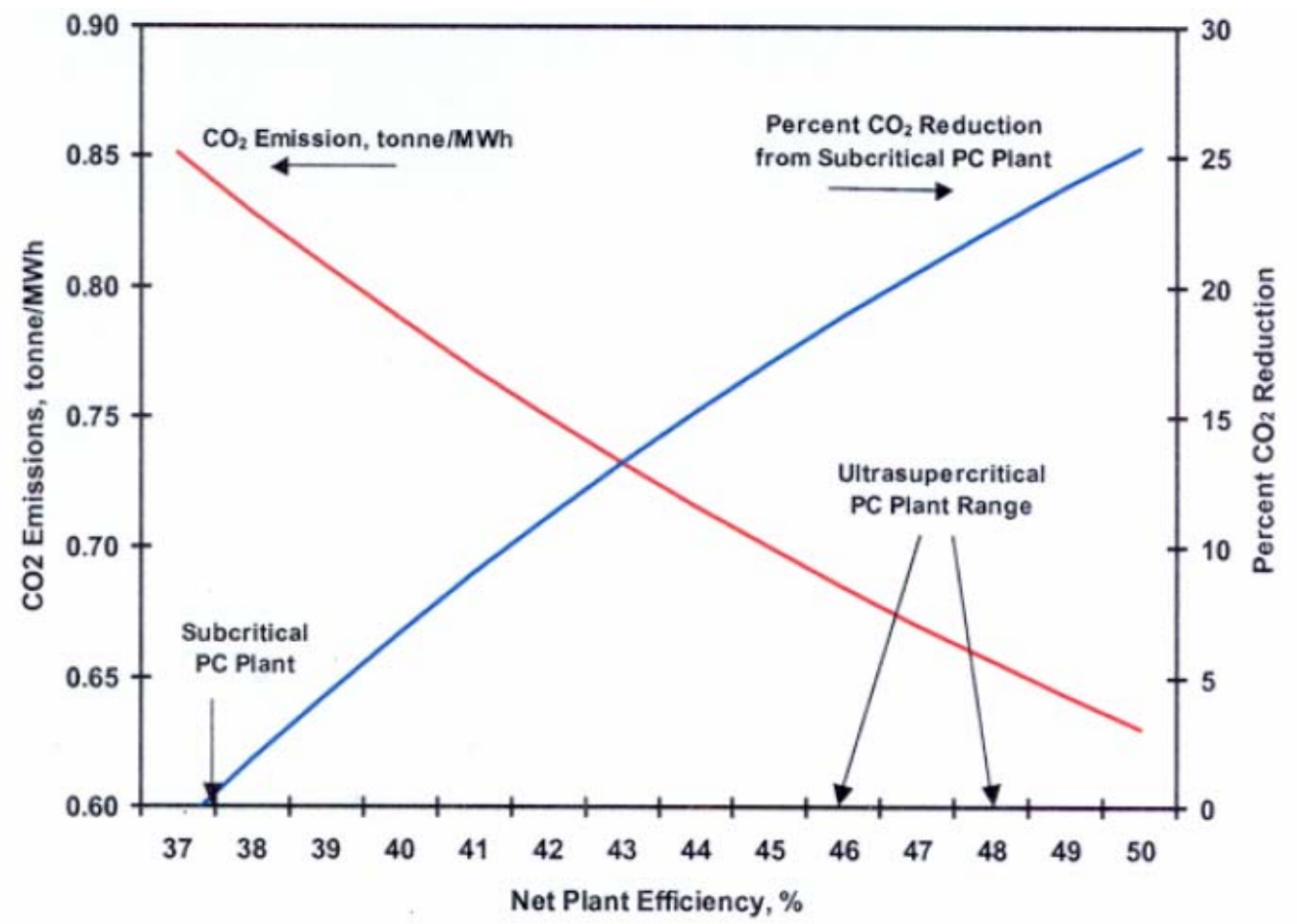

Figure 1. Carbon Dioxide Emissions vs. Net Plant Efficiency (G. Booras, EPRI).

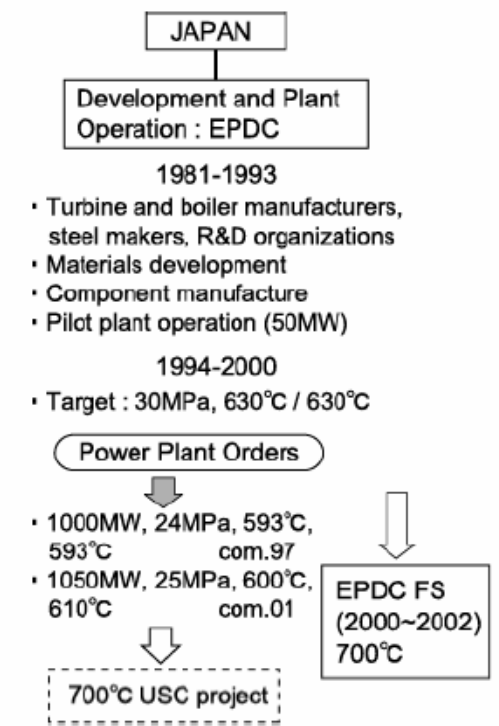

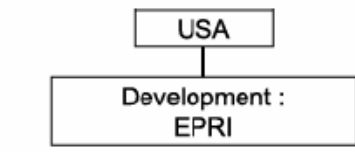

- Basic studies (1978-1980)

- Turbine and boiler manufacturers (1986-1993)

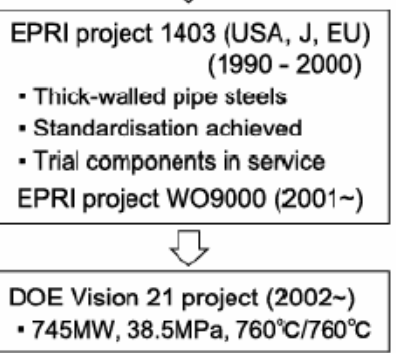
- $745 \mathrm{MW}, 38.5 \mathrm{MPa}, 760^{\circ} \mathrm{C} / 760^{\circ} \mathrm{C}$

Figure 2. History of steam turbine material development programs (F. Masuyama, Kyushu Institute of Technology) 


\section{STEAM TURBINE HISTORY}

During the 1950's rapid increases in steam turbine operating temperature were achieved, culminating in turbines running at $650^{\circ} \mathrm{C}\left(1200^{\circ} \mathrm{F}\right)$. These turbines used austenitic rotors and casings to achieve the extremely high temperatures used. However, the turbines were relatively small, mainly under 50MW. This meant that the large thermal expansion coefficients and low thermal conductivity inherent in austenitic materials where not such a hindrance as they would be with larger turbines. Even so, there were a lot of initial problems with these turbines due to the thermal expansion and the tendency of austenitic alloys to undergo severe oxide spalation during shutdowns. It should be noted that the issues with these turbines (predominantly manufactured by Westinghouse - now Siemens Power Generation) were resolved, and they ran (and continue to run, though de-rated) for many years. This initial experience caused a wave of conservatism on the part of the electricity generation industry, particularly in the United States. This can be clearly seen in Figure 3, the HP rotor inlet temperature stabilized around $540^{\circ} \mathrm{C}\left(1000^{\circ} \mathrm{F}\right)$ from the 1960's up until the early part of the 1990's. At this time the first combined cycle (CC) gas turbine plants started to appear. These power plants consist of a gas turbine which generates electricity along with a HRSG (Heat Recovery Steam Generator), which uses the heat from the gas turbine exhaust to generate steam to run a steam turbine. Such combined cycle plants can run at efficiencies of up to $60 \%$ today. As gas turbine firing temperatures rose throughout the 1990's, the exhaust temperatures followed suite. This resulted in a demand for higher temperature capable steam turbines. The technology developed for these CC plants then fed into conventional steam turbine designs, leading to a sudden jump in capability of these plants. Temperatures rose rapidly, culminating in turbines in Japan running at around $620^{\circ} \mathrm{C}\left(1148^{\circ} \mathrm{F}\right)$, the ceiling temperature of the best ferritic alloy (T122). Long term use of this alloy showed poorer creep properties than expected, resulting in early retrofits of these plants, and a back-off in maximum temperature to about $600^{\circ} \mathrm{C}$ $\left(1112^{\circ} \mathrm{F}\right)$ in the last 3-4 years. More conservatism has been shown in European and American designs, which have more slowly closed in on $600^{\circ} \mathrm{C}\left(1112^{\circ} \mathrm{F}\right)$ over the last few years (Figure 4). Cooling steam in being introduced in Siemens turbine designs to reduce the metal temperatures as the limits of today's ferritic materials have been reached. Examples of Siemens high temperature $\left(\sim 600^{\circ} \mathrm{C} / 1112^{\circ} \mathrm{F}\right)$ turbine modules are shown in Figure 5 and Figure 6.

Had plants remained at the size that they were in the 1950s, it is likely that austenitic (i.e. high chromium) steels could have been used today, however, the increased size of modern plant (Figure 7) combined with the poor thermal expansion characteristics preclude its use.

The adoption of Nickel-base alloys is likely to produce a step-change in temperature due to the greatly improved mechanical performance and environmental resistance of these materials. The greatly increased cost will probably prohibit small temperature gains, as the cost delta would be too great to justify. 


\section{Operating Temperatures of HP Rotors \\ (Ferritic Rotors)}

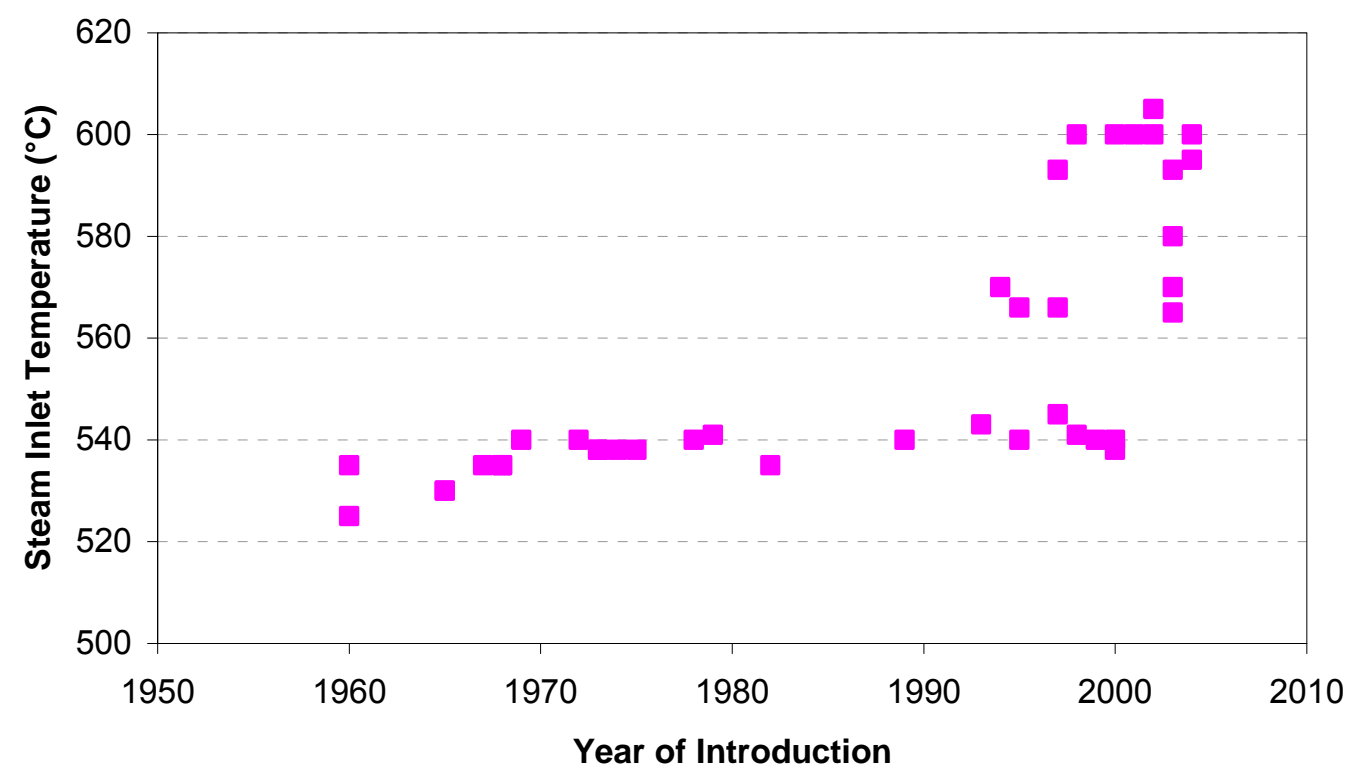

Figure 3. Operating temperature of sample steam turbines over the last 50 years

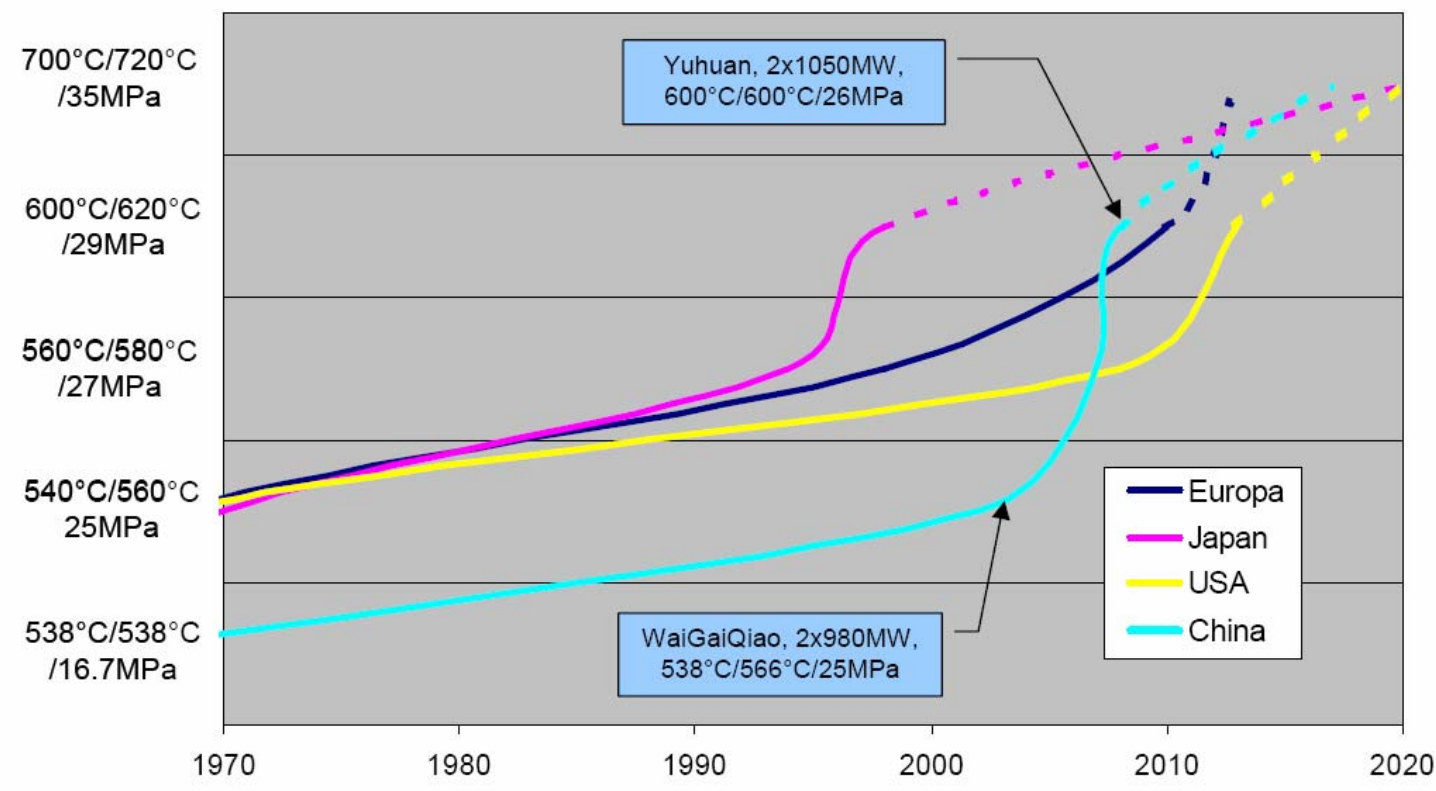

Figure 4. Comparison of the development of turbine operating temperatures within 4 major markets ${ }^{1}$ 


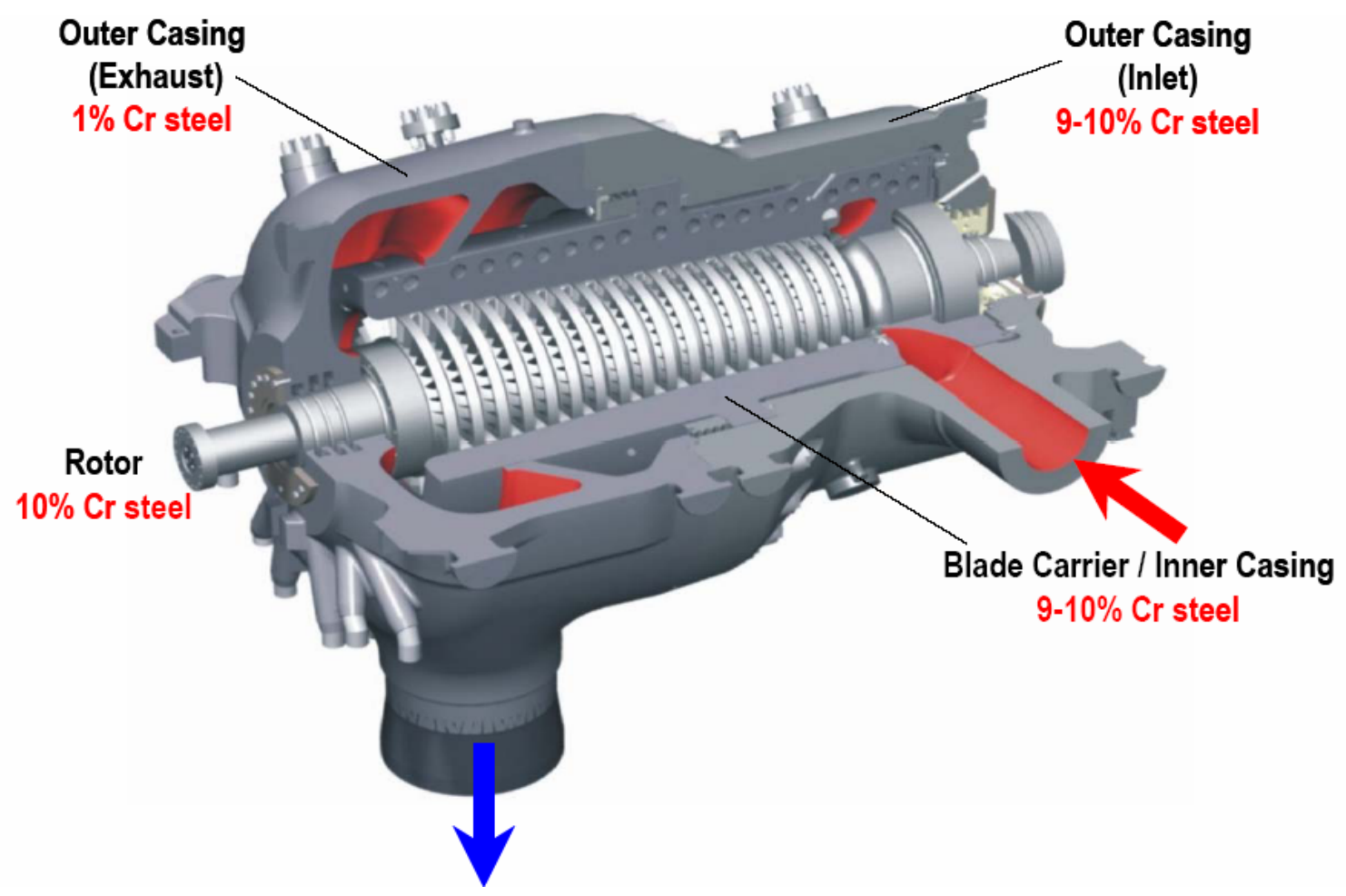

Figure 5. Uncooled Siemens $600^{\circ} \mathrm{C} / 300$ bar $\left(1112^{\circ} \mathrm{F} / 4350\right.$ psi) HP turbine module

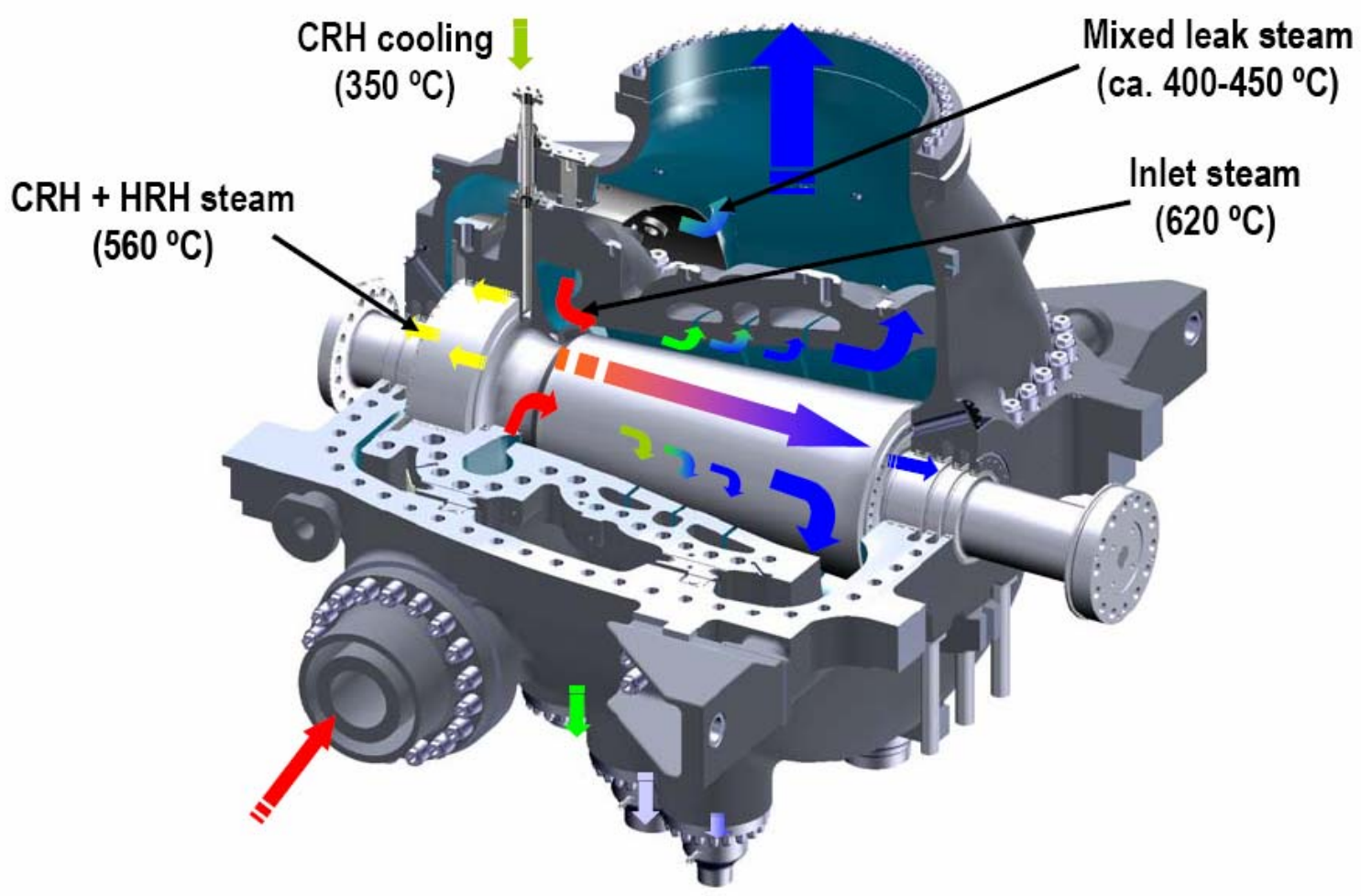

Figure 6. Cooled Siemens $620^{\circ} \mathrm{C}\left(1148^{\circ} \mathrm{F}\right)$ IP turbine design 


\section{Evolution of Power Plant Size}

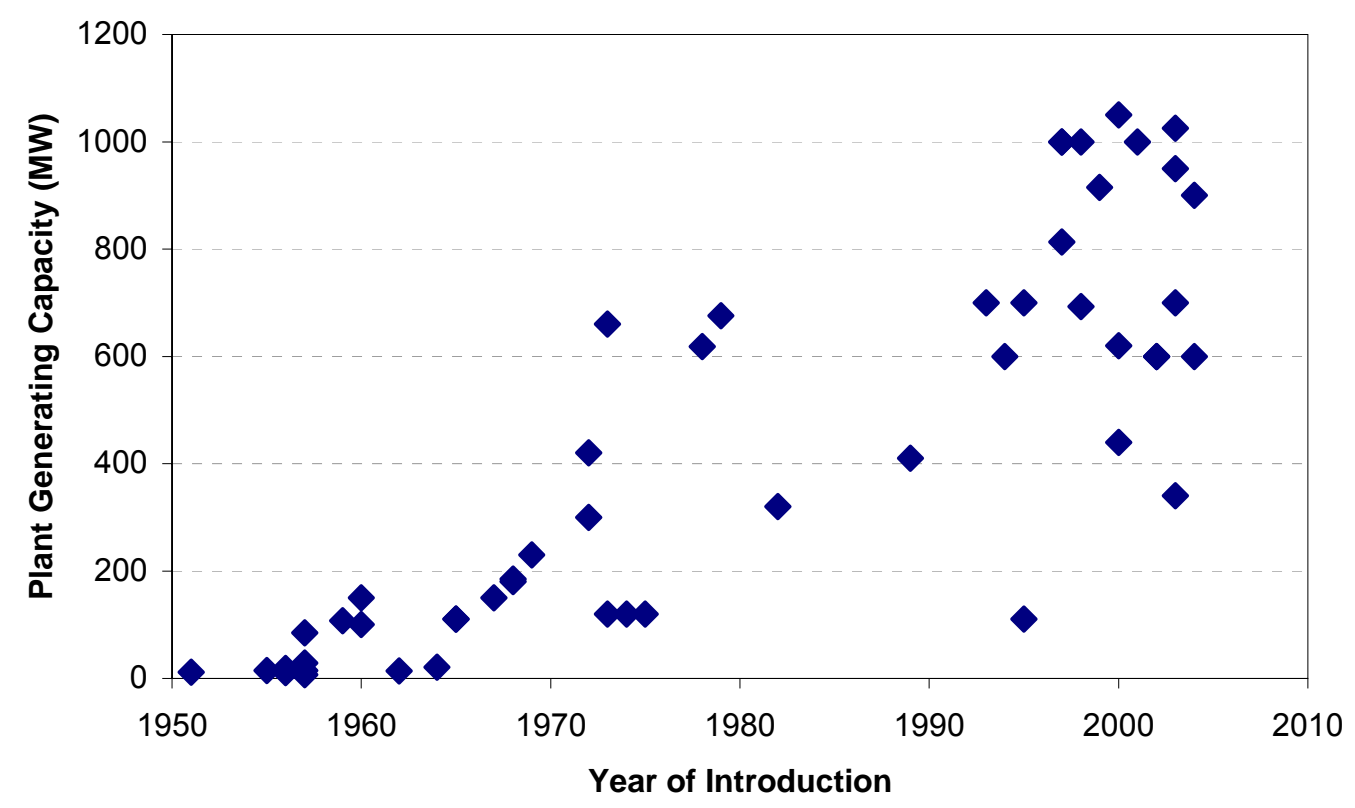

Figure 7. Size of a selection of powerplants built over the last 50 years

\subsection{Ferritic Alloys}

ASME Grade 91 is one of the first high temperature of grades $9 \% \mathrm{Cr}$ steels used in steam turbines, which represented a significant increase in properties over previous materials, such as X20. Grade 91 achieved its properties by reducing the chromium level from $11-12 \%$ down to $9 \%$, and adding Mo. Its development began as early as 1975 , providing a relatively simple $9 \mathrm{Cr}-1$ Mo composition. By 1980 , the addition of $\mathrm{V}, \mathrm{Nb}, \mathrm{N}, \mathrm{Al}$ and $\mathrm{Ni}$ resulted in a version, T91, which had creep properties equal to that of 304SS. The properties obtained provide a mean $100,000 \mathrm{~h}$ creep rupture strength for $100 \mathrm{MPa}$ $(14.5 \mathrm{ksi})$ of approximately $580^{\circ} \mathrm{C}\left(1076^{\circ} \mathrm{F}\right)$ and for $50 \mathrm{MPa}(7.2 \mathrm{ksi})$ of $640^{\circ} \mathrm{C}\left(1184^{\circ} \mathrm{F}\right)$ based on mean data (Figure 8).

P91 has been successively improved by the addition of $1 \% \mathrm{~W}$ (E911) and then $2 \% \mathrm{~W}$ (T92). T92 increased the $100 \mathrm{MPa} 100,000 \mathrm{~h}$ strength up to approximately $625^{\circ} \mathrm{C}$ $\left(1157^{\circ} \mathrm{F}\right)$ (Figure 9).

As the operating temperatures of these alloys rose, the oxidation behavior became more critical. As a consequence of this, the next evolution beyond P92, wasT122 which raised the $\mathrm{Cr}$ level back to the $12 \%$ found in X20, and silicon was also deliberately added to increase the oxidation resistance. Initial trials on T122 showed better creep resistance than P92 coupled with higher oxidation resistance, but longer term studies have shown it to be less stable, with a more rapid drop-off in long term creep behavior. This and similar compositions show improved creep strength in tests of between 5 and 10,000hrs at 
$650^{\circ} \mathrm{C}\left(1202^{\circ} \mathrm{F}\right)$, but in longer service all show a dramatic loss of strength beyond 30,000 hrs (Figure 10,Figure 11). This has been identified as being caused by the complex nitride Z-phase $(\mathrm{Cr}(\mathrm{V}, \mathrm{Nb}), \mathrm{N})^{2}$.

Beyond the currently used alloys, a number of improvements have been proposed. A recent EU program (COST522) has tested $11 \% \mathrm{Cr}$ steels with $\mathrm{B}$ and Co additions. This is intended to provide an approximately $25^{\circ} \mathrm{C}\left(45^{\circ} \mathrm{F}\right)$ benefit over the current P91 and P92 alloys(Figure 12,Figure 13).

Boron-containing steels have also been developed in Japan, where significant improvements over P92 (Figure 14) have also been demonstrated, again with Cobearing alloys ${ }^{3}$. These have been further improved with the addition of nitrogen to produce grain boundary pinning BN particles as a replacement for $C$ (Figure 15). The controlled addition of $\mathrm{B}$ and $\mathrm{N}$ has significantly improved the reported properties with low levels of $\mathrm{N}$. However the reported results are mainly, at relatively short times and thus there is a risk of the formation of complex nitride Z-phase $(\mathrm{Cr}(\mathrm{V}, \mathrm{Nb}), \mathrm{N})$ as found elsewhere at longer exposures ${ }^{4}$. The results for 34 ppm N and 140 ppm B do not show any drop-off in properties after $30,000 \mathrm{hrs}$, so it may be that the solubility limit for Z-phase formation has not been exceeded. The creep strengths of a range of the steels discussed here are compared in Figure 16.

\subsubsection{Conclusion}

Ferritic rotor steels are available which can be used at temperatures up to around $620^{\circ} \mathrm{C}$ $\left(1148^{\circ} \mathrm{F}\right)$. The long term strength of the highest temperature steels is questionable though, as the precipitation of Z-phase in nitrided steels, which most of the highest temperature ones are, occurs at very long exposures, but within the likely lifetime of a rotor component.

\subsection{Austenitic Alloys}

Austenitic alloys, whilst more oxidation resistant the ferritics, suffer from a number of disadvantages. The largest of these, as mentioned above is that the thermal expansion coefficients are significantly higher than for the other material classes, reducing the efficiency of the turbines due to larger clearance requirements and degrading life due to the larger thermal loads during start-up and shut-down.

\subsection{Superalloys}

Superalloy performance greatly exceeds that of both austenitic and ferritic steels in both mechanical and environmental resistance. There are two classes of superalloys, solution hardened which were first used in the 1940s and precipitation strengthened, which were introduced in the 1960s. Selected potential alloys are shown in Table 2.

\subsubsection{Solution strengthened alloys}

These alloys rely on refractory metal additions for mechanical strength, typically containing varying levels of tungsten, molybdenum and cobalt as well as boron and carbon. Initial alloys contained large fractions of iron, and were derived from austenitic alloys. More modern alloys eliminated the iron for higher strength and corrosion/oxidation resistance. In addition to the solution strengthening, the formation of 
$\mathrm{M}_{23} \mathrm{C}_{6}$-type carbides on the grain boundaries restrict grain growth. For oxidation resistance $15-25 \% \mathrm{Cr}$ is added. The chromium forms a stable chromia layer. Certain alloys, such as Haynes 230 contain lanthanum to reduce the sulfur level and increase the chromia stability. Sample alloys (including particle strengthened ones) are shown in Table 2. Though the strength of these alloys is high, they are still soft enough at high temperatures to be forged. In terms of steam turbine usage, these alloys are suitable for casings, disk forgings, blading and auxiliary components. As was demonstrated in the Thermie project, the highest strength alloys such as IN 617 and IN 625 provide sufficient strength for usage as rotor materials at temperatures up to $700^{\circ} \mathrm{C}\left(1292^{\circ} \mathrm{F}\right)$. Due to the relatively easy forgability, entire IN 617 and IN 625 rotors have been manufactured as demonstrator components. The IN 617 rotor forgings were up to $1000 \mathrm{~mm}$ (39") in diameter and $1350 \mathrm{~mm}$ (53") long the IN 625 ones up to $700 \mathrm{~mm}$ (29") in diameter.

Casting of such alloys in large components is difficult due to segregation issues, but with improved modeling of the process, may be successful.

\subsubsection{Particle strengthened alloys}

These alloys rely on either $\mathrm{Ni}_{3} \mathrm{Al}$ or $\mathrm{Ni}_{3}(\mathrm{Ti}, \mathrm{Nb})$ particles, known as $\mathrm{Y}^{\prime}$ and $\mathrm{y}^{\prime \prime}$ respectively for their strength. The $\mathrm{Y}^{\prime \prime}$ phase is not stable at temperatures over about $600^{\circ} \mathrm{C}$ $\left(1112^{\circ} \mathrm{F}\right)$, and thus will not be discussed further.

The $y^{\prime}$ phase particles are produced in the alloy in regular formations by a combination of solution treatment and aging. The precipitation is initially coherent, but due to a slight difference in lattice parameter with the matrix (typically under $0.3 \%$ ), become incoherent with time. The $y^{\prime}$ volume fraction in these alloys varies from $20 \%$ up to as high as $70 \%$ in modern high temperature gas turbine blading alloys. In the older alloys, the mass fraction of chromium remains above $16 \%$ as in the solution strengthened materials. This, combined with a low level of aluminum gives oxidation and corrosion resistance through a stable chromia layer. High strength alloys with less than $10 \% \mathrm{Cr}$ and typically $5 \%$ or more of aluminum produce a stable alumina $\mathrm{Al}_{2} \mathrm{O}_{3}$ film. Alloys with intermediate $\mathrm{Cr}$ and Al levels produce less stable mixed oxides. These alloys are the only ones sufficiently strong to operate in the conditions needed for USC turbines. The high temperature strength of these alloys makes forging difficult. Alloys containing more than about $50 \%$ of $\mathrm{Y}^{\prime}$ phase cannot be forged, and must be used in the cast condition. There is a limited number of alloys with sufficient strength and forgability for rotor applications. It is unlikely that monobloc rotors would be possible in these alloys. As a consequence, a rotor constructed of a series of disks, such as are used in gas turbine compressors is the most promising design. The highest temperature forgeable alloys can only be forged using isothermal forging methods, limiting the component size. 
Table 2. Selected potential candidate alloys for USC steam turbine operation

\begin{tabular}{|c|c|c|c|c|c|c|c|c|c|c|c|c|c|c|c|c|}
\hline Alloy & $\begin{array}{l}\text { Potential } \\
\text { application }\end{array}$ & $\mathrm{Ni}$ & Al & B & C & Co & $\mathrm{Cr}$ & $\mathrm{Fe}$ & Si & Mo & $\mathrm{Nb}$ & Mn & $\mathrm{Ti}$ & $\mathbf{W}$ & $\mathrm{Zr}$ & Other \\
\hline IN 625 & $\begin{array}{l}\text { Casing / } \\
\text { rotor }\end{array}$ & 62 & & & & & 21 & & & 9 & 3.7 & & & & & \\
\hline IN 617 & $\begin{array}{l}\text { Casing / } \\
\text { rotor }\end{array}$ & 52 & 1.2 & & & 12.5 & 22 & 1.5 & & 9.5 & & & & & & \\
\hline IN 706 & Rotors & 41.5 & 0.2 & & & & 16 & 37 & & & 2.9 & & 1.8 & & & \\
\hline IN 718 & Rotors & 54 & & & & & 18 & 18.5 & & 3 & 5 & & 1 & & & \\
\hline IN 740 & $\begin{array}{l}\text { Casings, } \\
\text { pipes }\end{array}$ & Bal. & 0.9 & & & 20 & 25 & 0.7 & 0.5 & 0.5 & 2 & 0.3 & 1.8 & & & \\
\hline C 263 & Casings & 52 & & & 0.06 & 20 & 20 & & & 6 & & & & & & \\
\hline $\mathrm{H} 230$ & Pipes & Bal & & & 0.1 & 5 & 22 & 3 & 0.5 & 2 & & 0.7 & & 14 & & $\begin{array}{l}0.02 \\
\text { La }\end{array}$ \\
\hline IN 100 & $\begin{array}{l}\text { Blades and } \\
\text { vanes }\end{array}$ & Bal & 5.4 & 0.015 & 0.06 & 15 & 10 & & & 3 & & & 4.5 & & 0.06 & \\
\hline Allvac 718+ & Rotors & Bal & 1.5 & & 0.025 & 9 & 17.5 & 10 & & 2.7 & 5.4 & & 0.7 & 1 & & \\
\hline $\begin{array}{l}\text { Haynes } \\
282\end{array}$ & $\begin{array}{l}\text { Casing and } \\
\text { pipes }\end{array}$ & Bal & 1.5 & 0.005 & 0.06 & 10 & 19.5 & 1.5 & 0.15 & 8.5 & & & 2.1 & & & \\
\hline
\end{tabular}




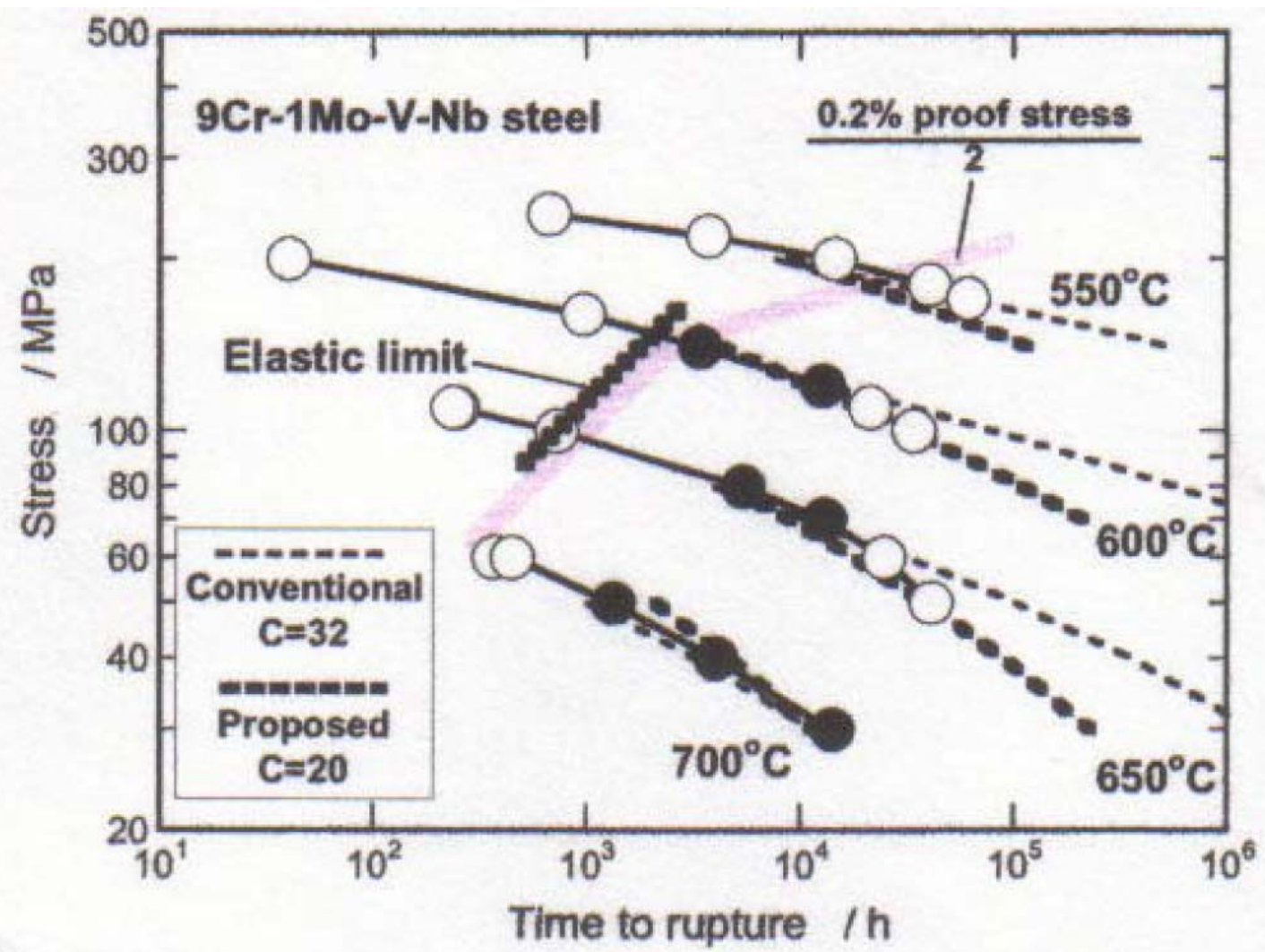

Figure 8. Stress vs. rupture life for Grade 91 showing the original extrapolation $(C=32)$ and extrapolation based on newer long term data $(C=20)^{5}$

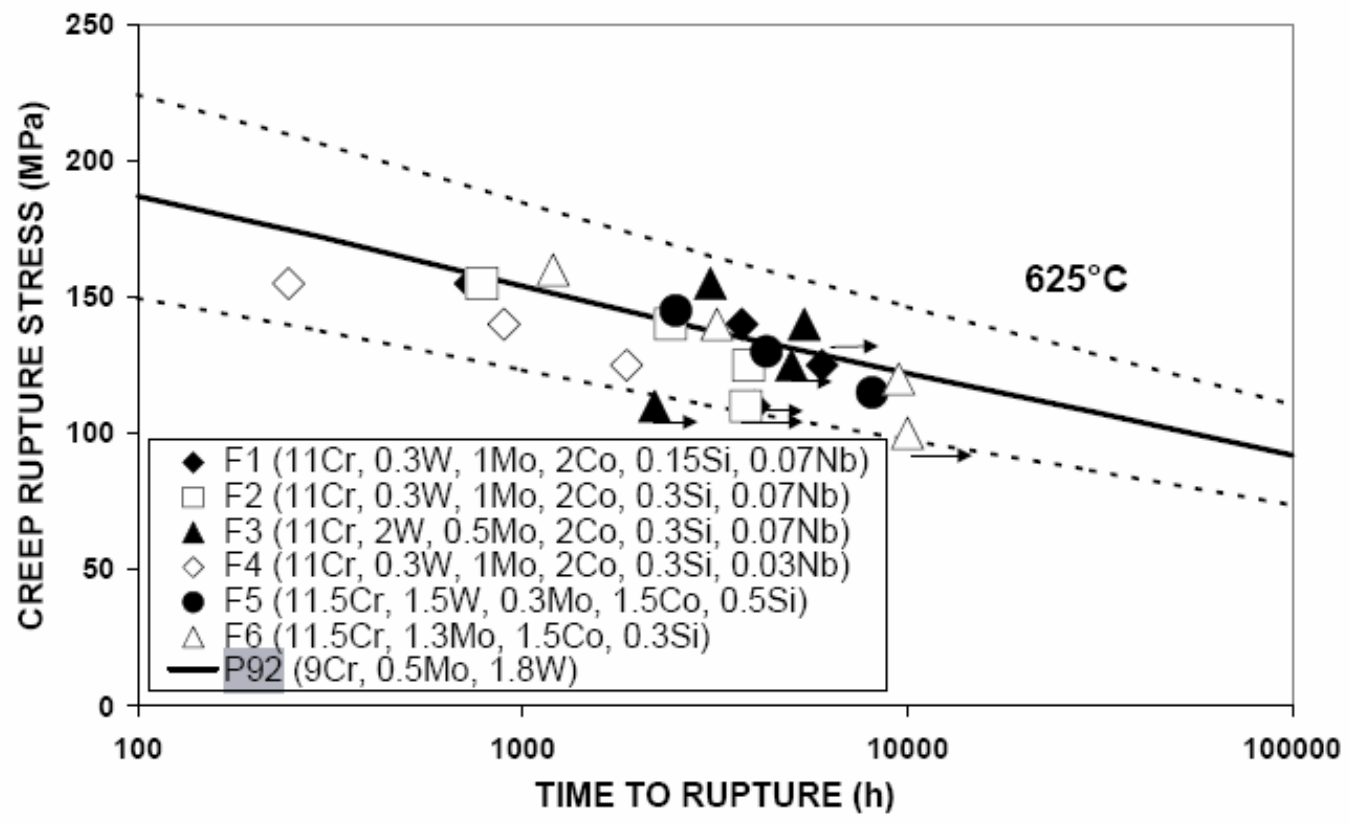

Figure 9. Rupture strength of P92 and related alloys ${ }^{6}$ 


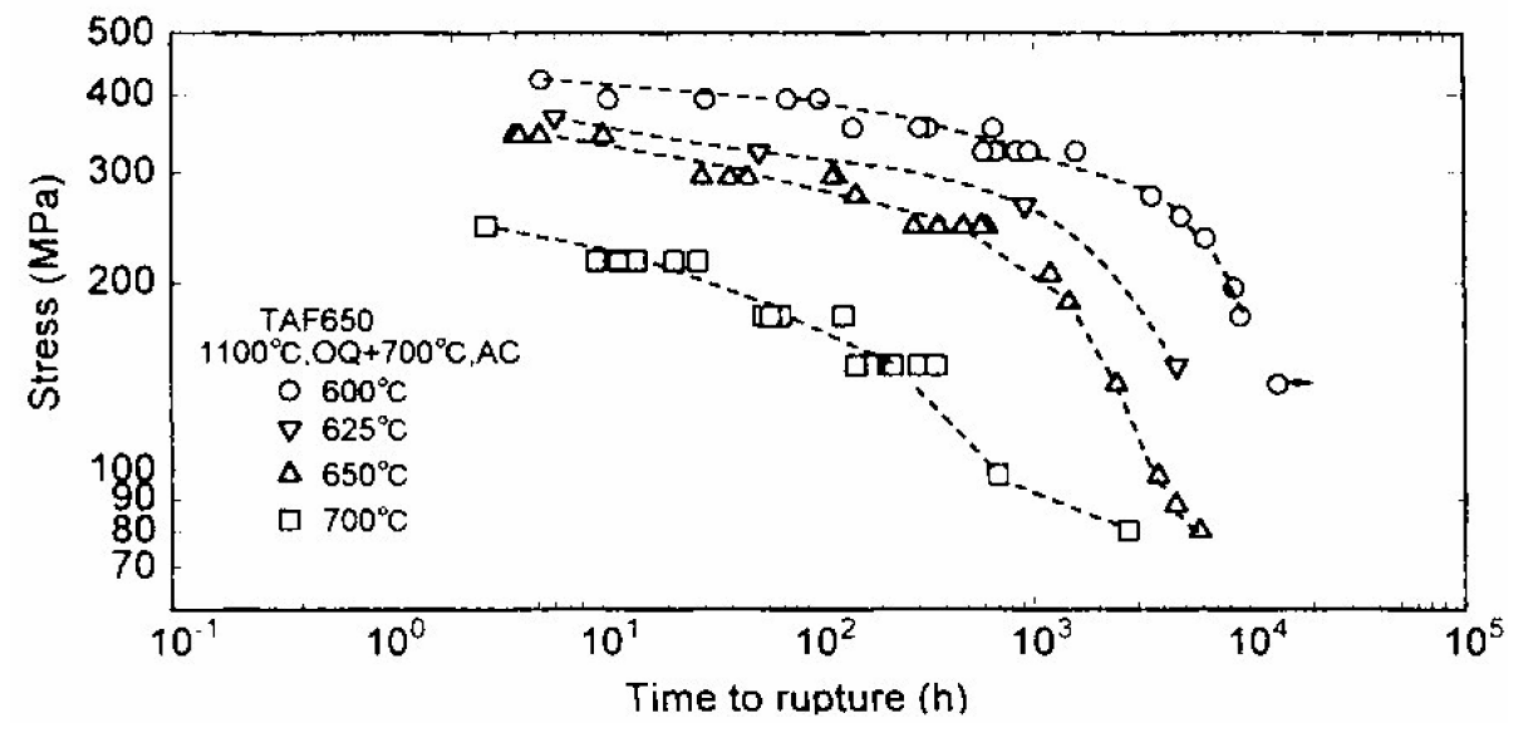

Figure 10. Loss of creep strength at 30,000 hrs in TAF650 steel ${ }^{7}$

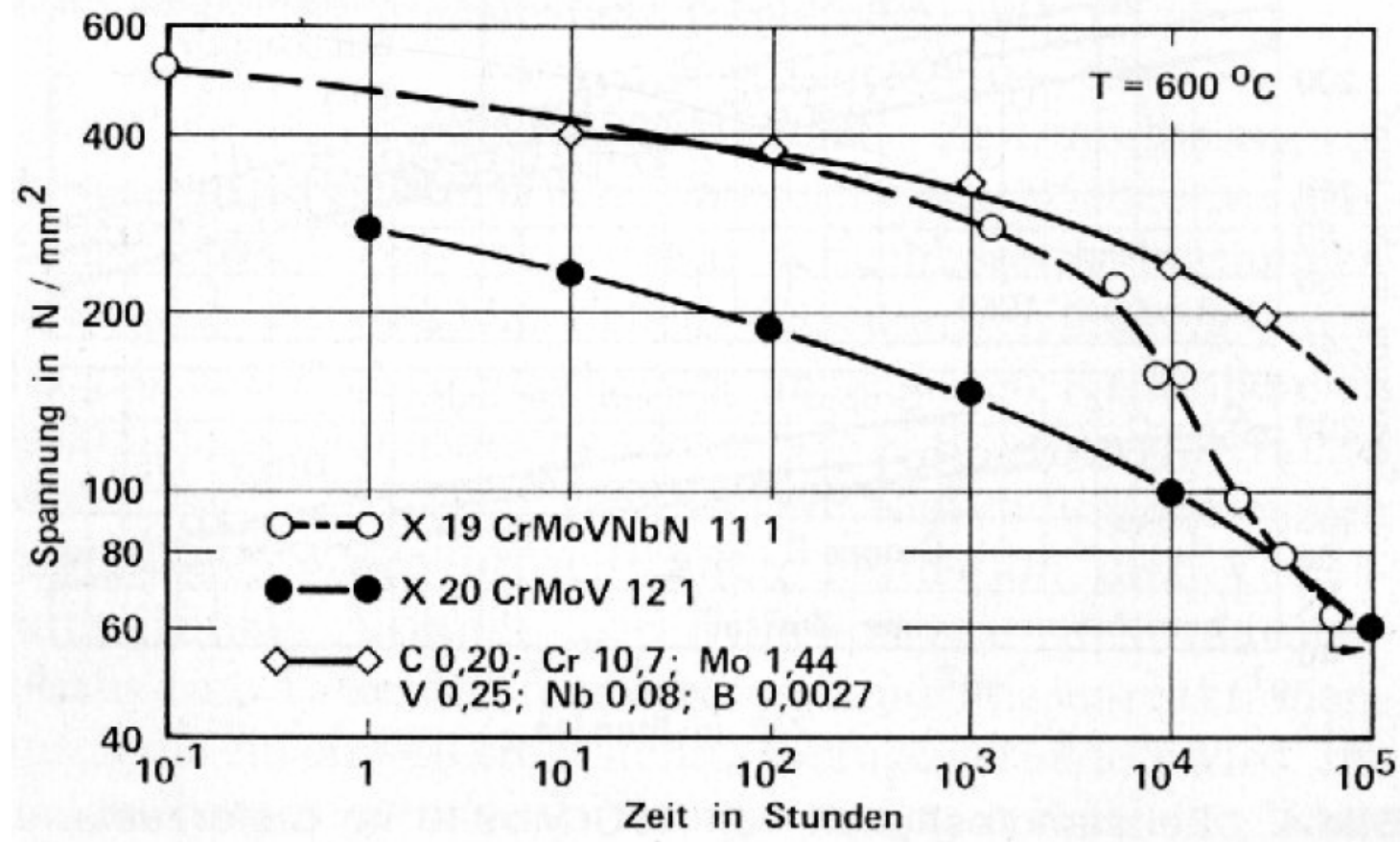

Figure 11. Creep strength in $39-12 \%$ Cr steels. X19 forms Z phase, the other two do not. $^{8}$ 


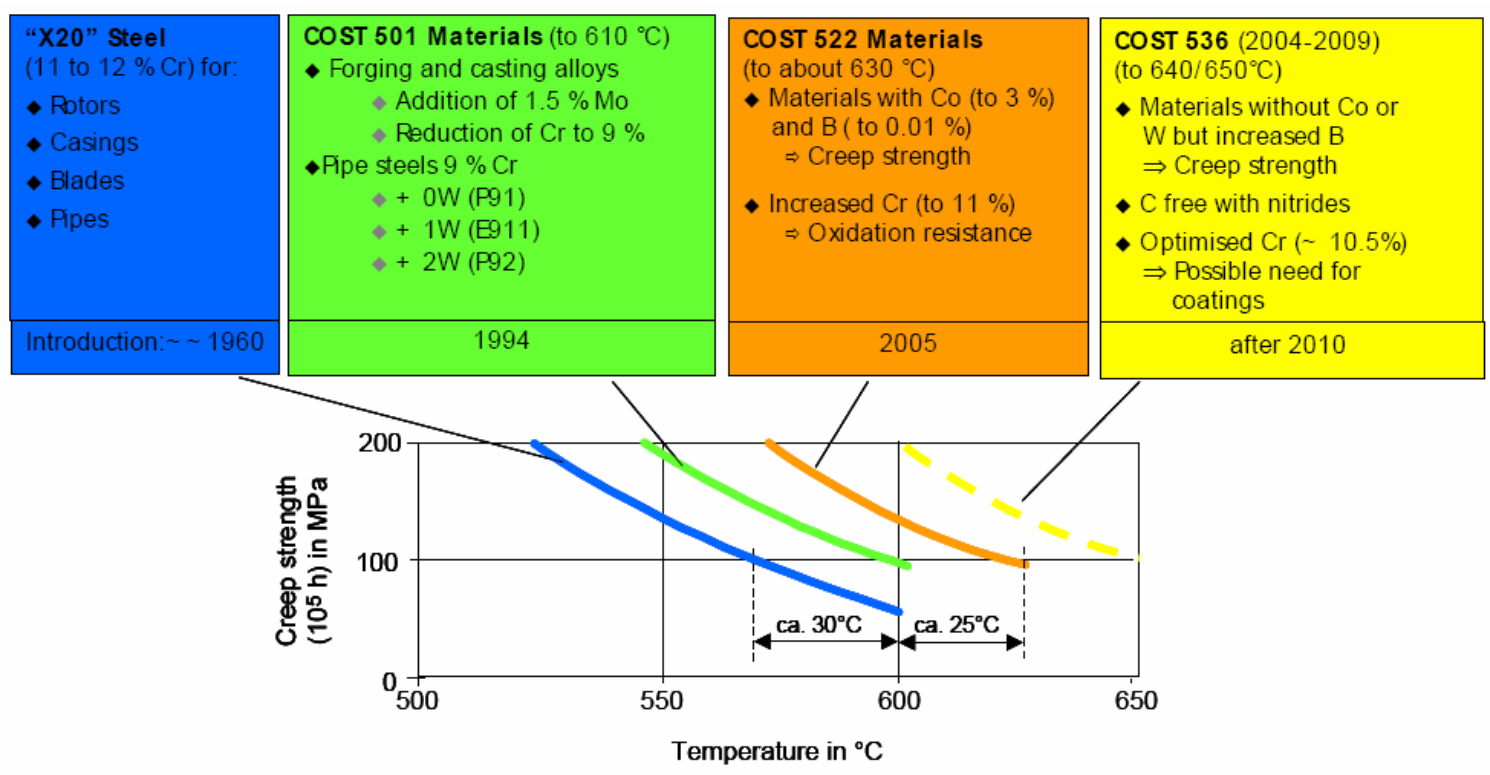

Figure 12. European COST steel development programs and the expected usability temperatures $\left(\text { in }^{\circ} \mathrm{C}\right)^{6}$

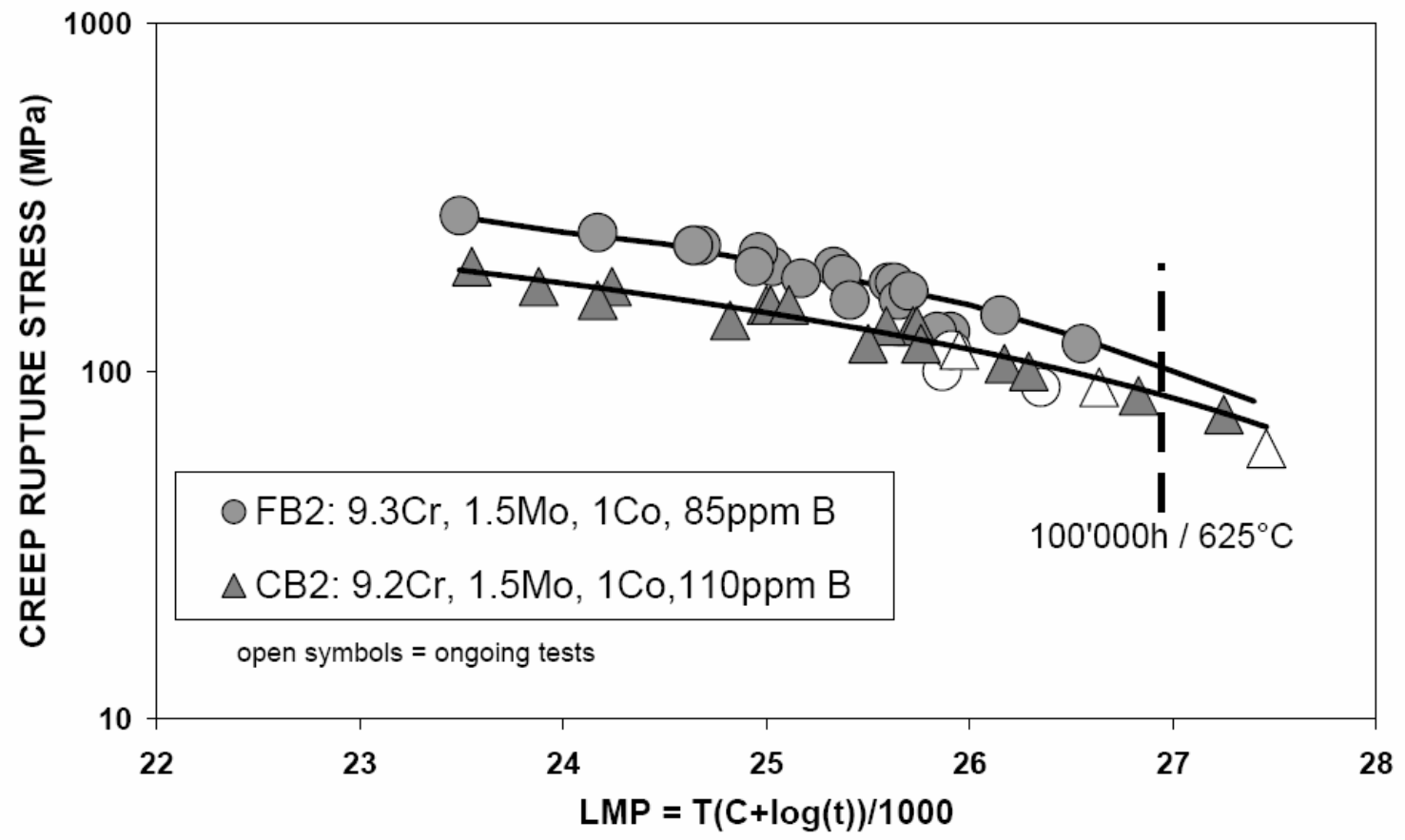

Figure 13. Promising compositions from the COST 522 program $^{9}$ 


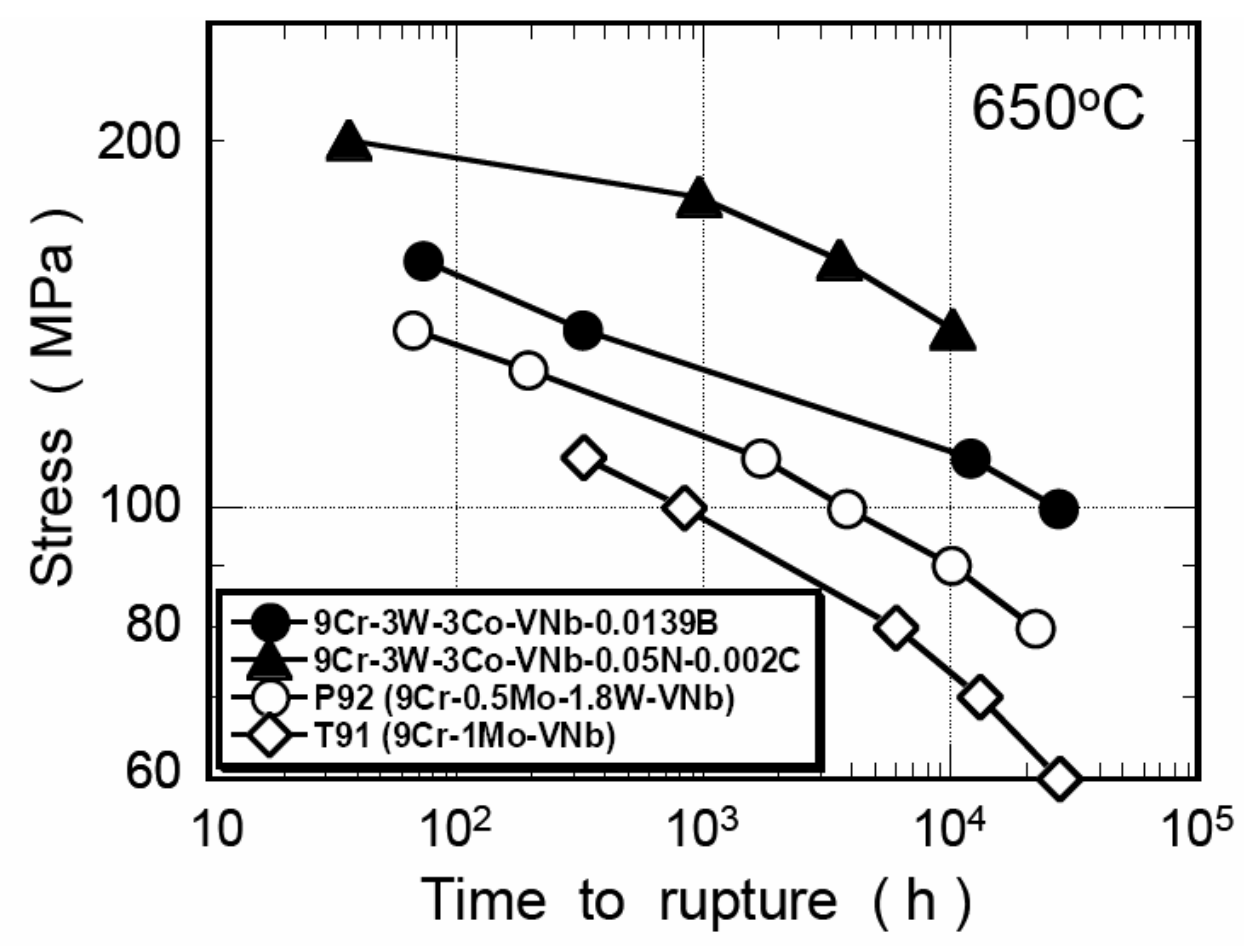

Figure 14. Post-P92 steels developed in Japan ${ }^{3}$

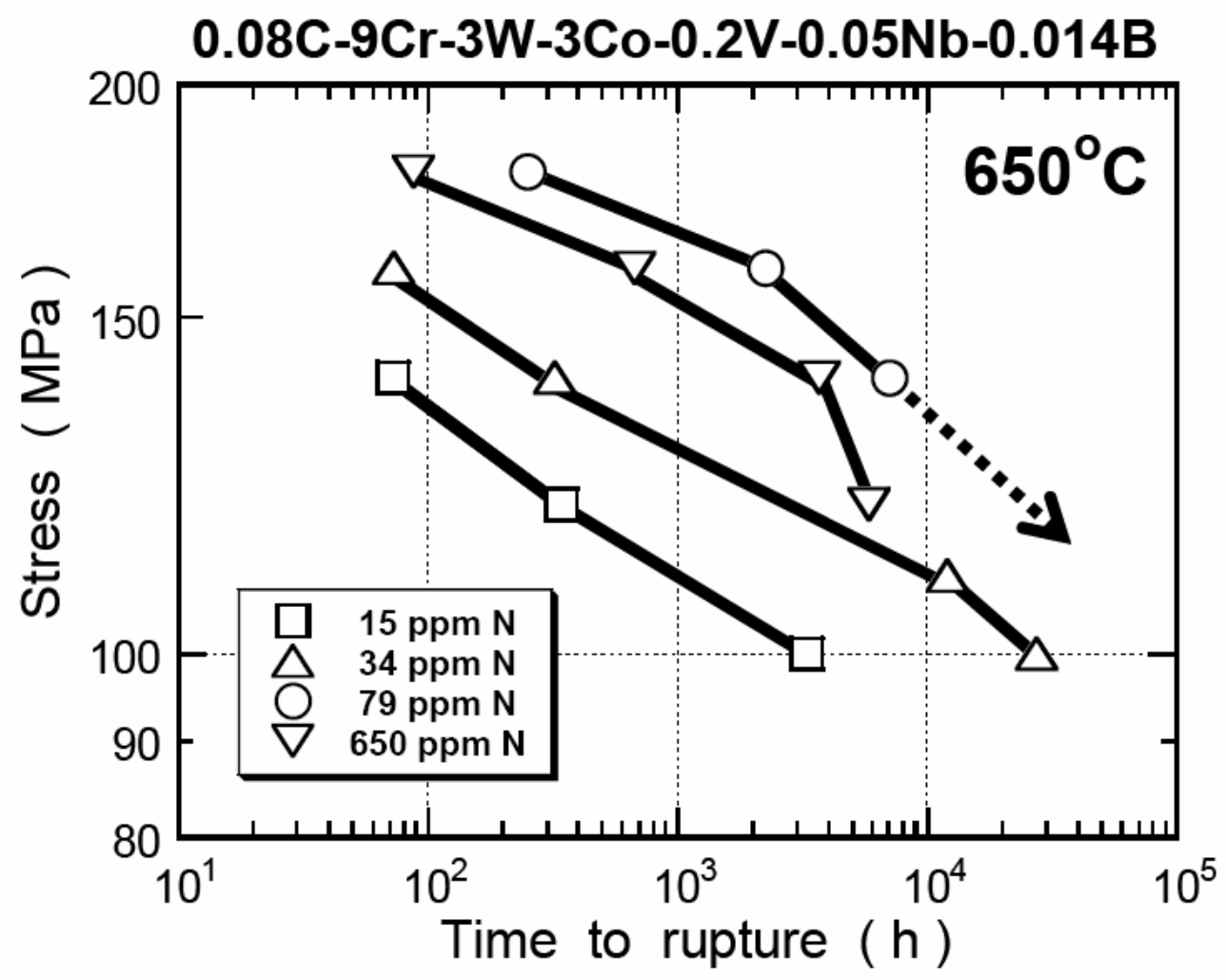

Figure 15. Effect of boron nitride precipitation in ferritic steels ${ }^{3}$ 


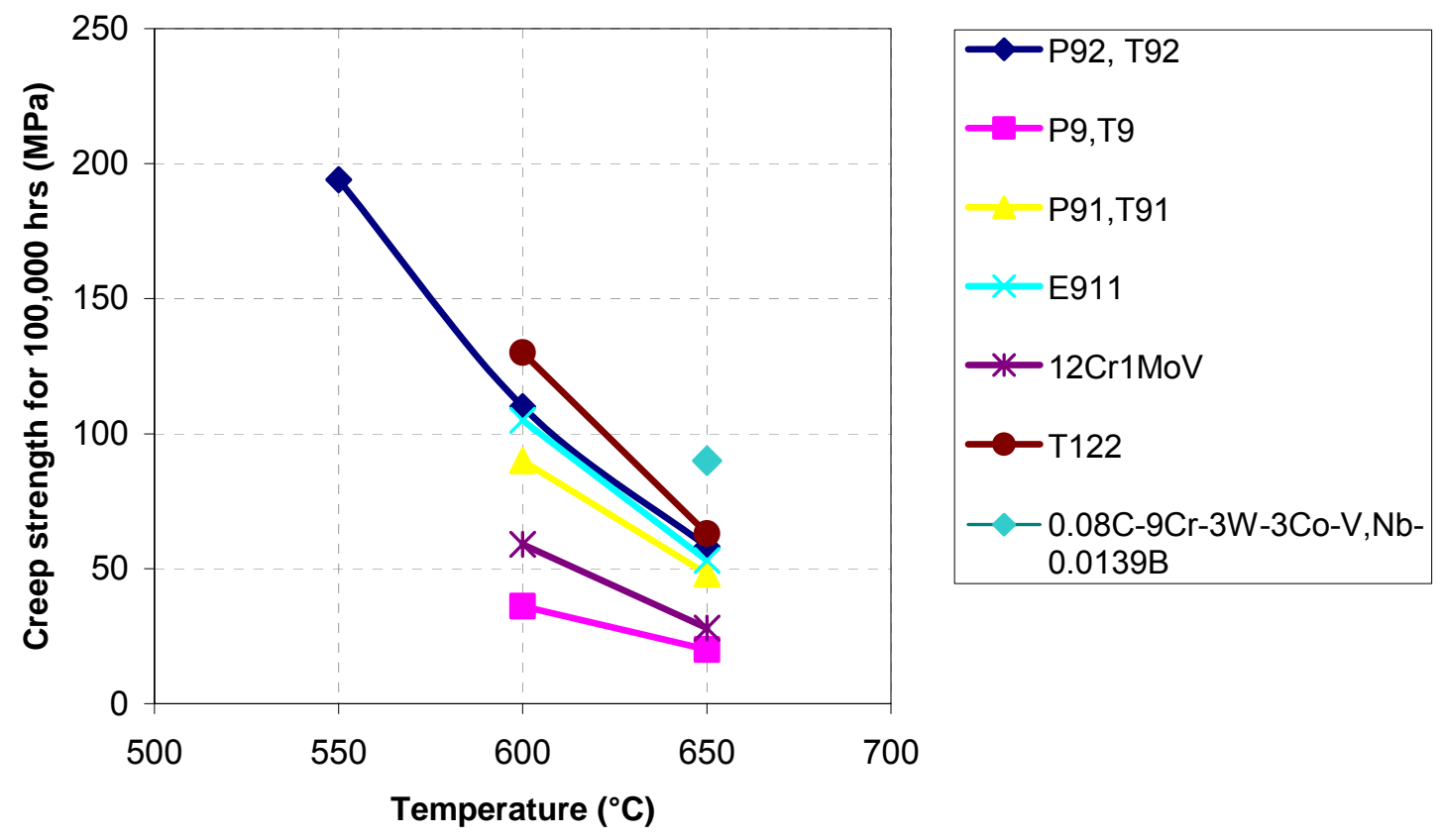

Figure 16. Summary of literature values for 100 000h creep strength of ferritic rotor steels ${ }^{10-11}$ 


\section{TESTING OF CF8C+ ALLOY}

\subsection{Introduction}

As part of the project, the nano-hardened alloy CF8C+ was examined. The alloy is a modification of the standard stainless steel 347SS. The alloy, developed by ORNL is of a class of alloys referred to as "microstructure engineered". This indicates that a standard alloy is taken, and small changes on the composition are made to produce fine dispersions of hardening particles which are not present in the original alloy. In this case, the carbon content is raise to increase carbide precipitation along with the Mn level.. The maximum amount of Silicon is reduced (Table 3). The result of these changes is a more stable microstructure containing a distribution of nano-scaled $\mathrm{NbC}$ and $\mathrm{Cr}_{23} \mathrm{C}_{6}$ carbides. Nitrogen is deliberately added to produce fine scale nitride particles. These have a significant benefit in terms of creep strength without an adverse effect on the tensile and fatigue properties. In this program, the validity of type approach was tested by running comparison tests on standard 347SS along with three different casts of CF8C+. The initial work on CF8C+ was carried out on sand cast keel bars. Subsequent work looked at the scale-up of the alloy into larger parts. The first of these steps was to produce centrifugally cast rings 12 " diameter rings, and then a large scale tube weighing $5500 \mathrm{lb}$. Mechanical tests on all of these have been completed, and are summarized below.

\subsection{Results}

The fatigue properties do not show any large differences as compared to the baseline 347SS (Figure 17), but creep and tensile properties show a significant improvement (Figure 17 to Figure 20). For a fair comparison we must consider the same casting method for the two alloys. If we do so, then the yield strength data for the two sand cast heats then CF8C+ is better, particularly at lower temperatures (Figure 18). The difference in the ultimate tensile strength is greater, and clear over the full temperature range (Figure 19). The differential varies with temperature but is typically around 60 $\mathrm{MPa}$.

On a like-for-like basis, the CF8C+ outperforms 347SS in terms of creep (Figure 20). If we compare the baseline 347SS data with the lowest data curve for $\mathrm{CF} 8 \mathrm{C}+$, then we have a $+40^{\circ} \mathrm{C}$ temperature capability for $100,000 \mathrm{hr} 100 \mathrm{MPa}$ creep rupture properties. Comparing the sand cast CF8C+ with the 347SS, which was also sand cast gives an even higher $+52^{\circ} \mathrm{C}$ increment.

\subsection{Conclusion}

The changes in microstructure within the alloy have significantly improved the creep strength of the alloy without noticeably weakening its fatigue resistance. The nanoparticle precipitation method used shows great promise for improving the properties of other alloy which may be of more direct relevance in turbine applications, particularly casing steels. 
Table 3. Composition and compositional specifications for the 347SS and CF8C+ heats used

\begin{tabular}{|c|c|c|c|c|c|c|c|c|c|c|c|c|c|c|}
\hline $\begin{array}{l}\text { Heat } \\
\text { No }\end{array}$ & Alloy & Condition & C & $\mathrm{Cr}$ & Mn & $\mathrm{Nb}$ & $\mathrm{Ni}$ & $\mathbf{P}$ & $S$ & Si & Mo & $\mathrm{Cu}$ & $\mathrm{N}_{2}$ & $\mathbf{W}$ \\
\hline $\begin{array}{l}\text { Spec } \\
\max \end{array}$ & CF8C+ & - & 0.10 & 20.0 & 5.0 & 1.0 & 13.5 & 0.03 & 0.03 & 0.50 & 0.40 & 0.3 & 0.30 & - \\
\hline $\begin{array}{l}\text { Spec } \\
\text { min }\end{array}$ & CF8C+ & - & 0.07 & 18.5 & 3.0 & 0.5 & 11.5 & - & - & 0 & 0.25 & - & 0.20 & - \\
\hline C5071 & CF8C+ & Sand cast & 0.09 & 19.19 & 4.22 & 0.79 & 12.53 & 0.01 & 0.00 & 0.42 & 0.29 & 0.05 & 0.25 & 0.04 \\
\hline C5072 & CF8C+ & $\mathrm{CF}^{*}$ ring & 0.09 & 19.08 & 4.23 & 0.81 & 12.59 & 0.01 & 0.00 & 0.42 & 0.31 & 0.05 & 0.24 & 0.04 \\
\hline H6843 & CF8C+ & $\mathrm{CF}^{*}$ tube & 0.09 & 19.20 & 3.96 & 0.78 & 12.61 & 0.023 & 0.00 & 0.34 & 0.33 & 0.06 & 0.23 & 0.04 \\
\hline $\begin{array}{l}\text { Spec } \\
\max \end{array}$ & $347 S S$ & & 0.08 & 21.0 & 1.50 & - & 12.0 & 0.04 & 0.04 & 2.00 & - & - & - & - \\
\hline $\begin{array}{l}\text { Spec } \\
\text { min }\end{array}$ & $347 S S$ & & - & 19.0 & - & - & 9.0 & - & - & - & - & - & - & - \\
\hline G7288 & $347 S S$ & Sand cast & 0.05 & 19.0 & 0.8 & 0.82 & 9.3 & 0.02 & 0.00 & 1.3 & - & - & - & - \\
\hline
\end{tabular}

${ }^{*}$ CF Centrifugally cast 


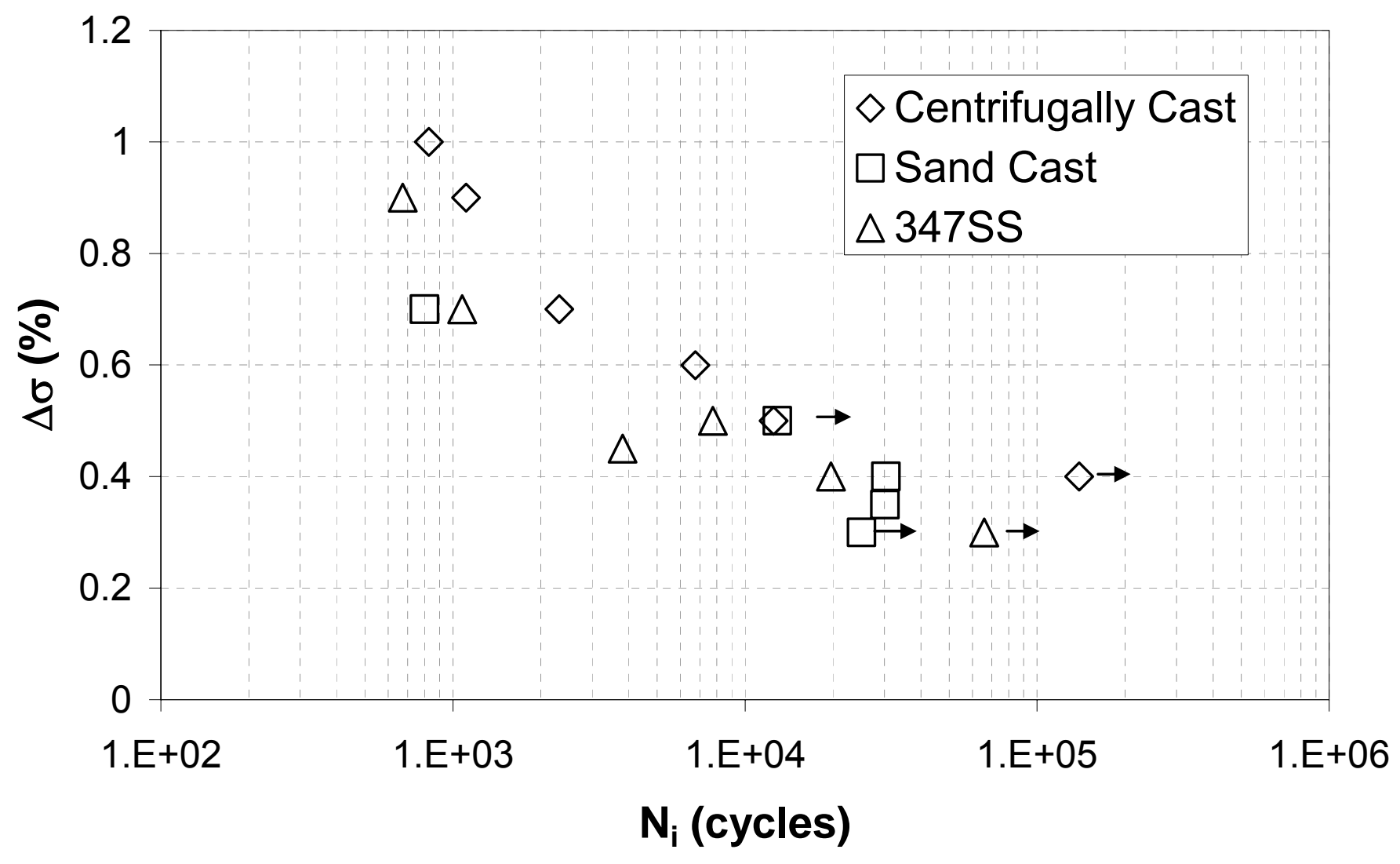

Figure 17. LCF comparison between $3475 S$ and CF8C+ 


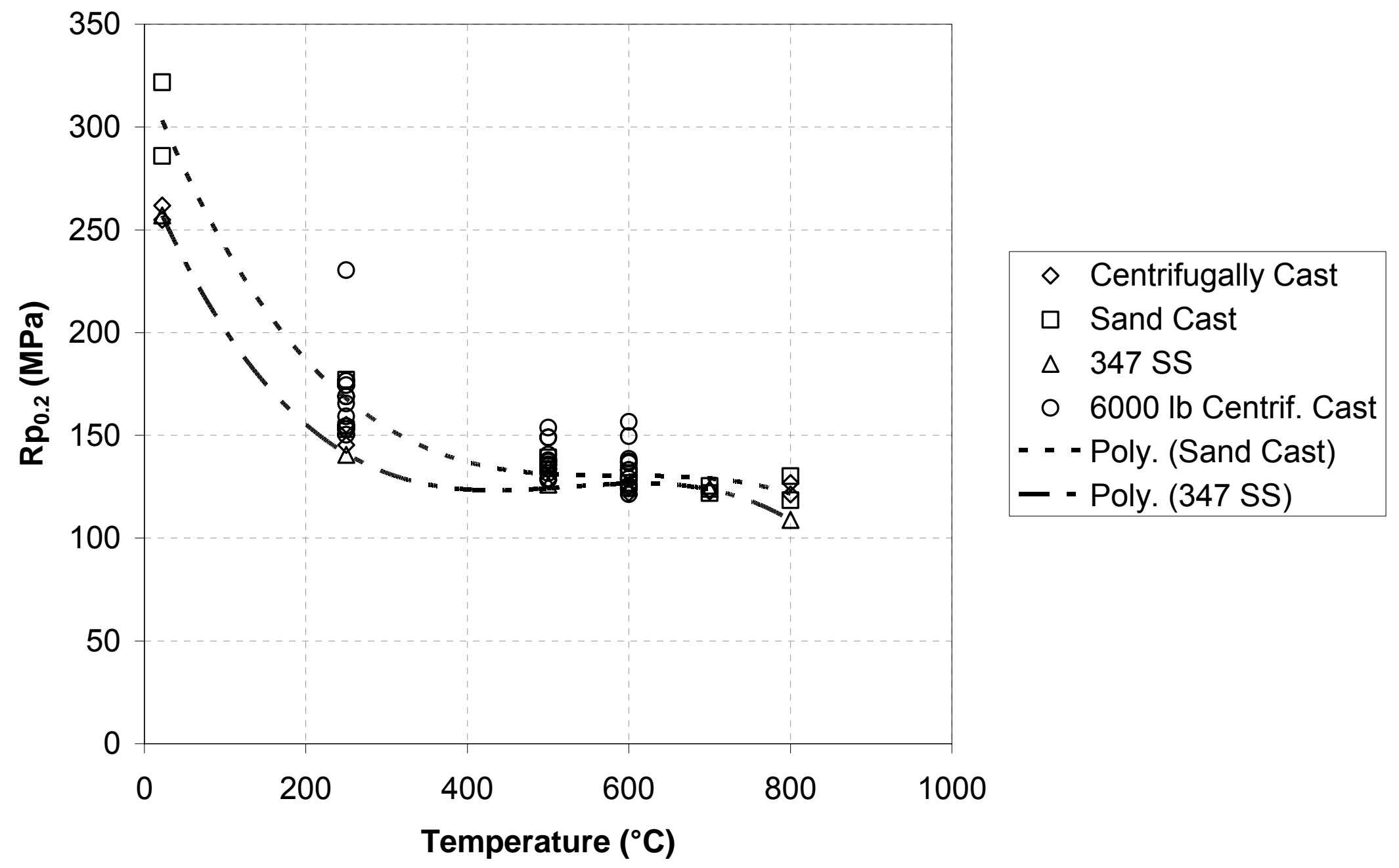

Figure 18. 0.2\% Yield stress comparison for the two alloys. On a like-for-like basis, the CF8C+ outperforms $347 S S$. 


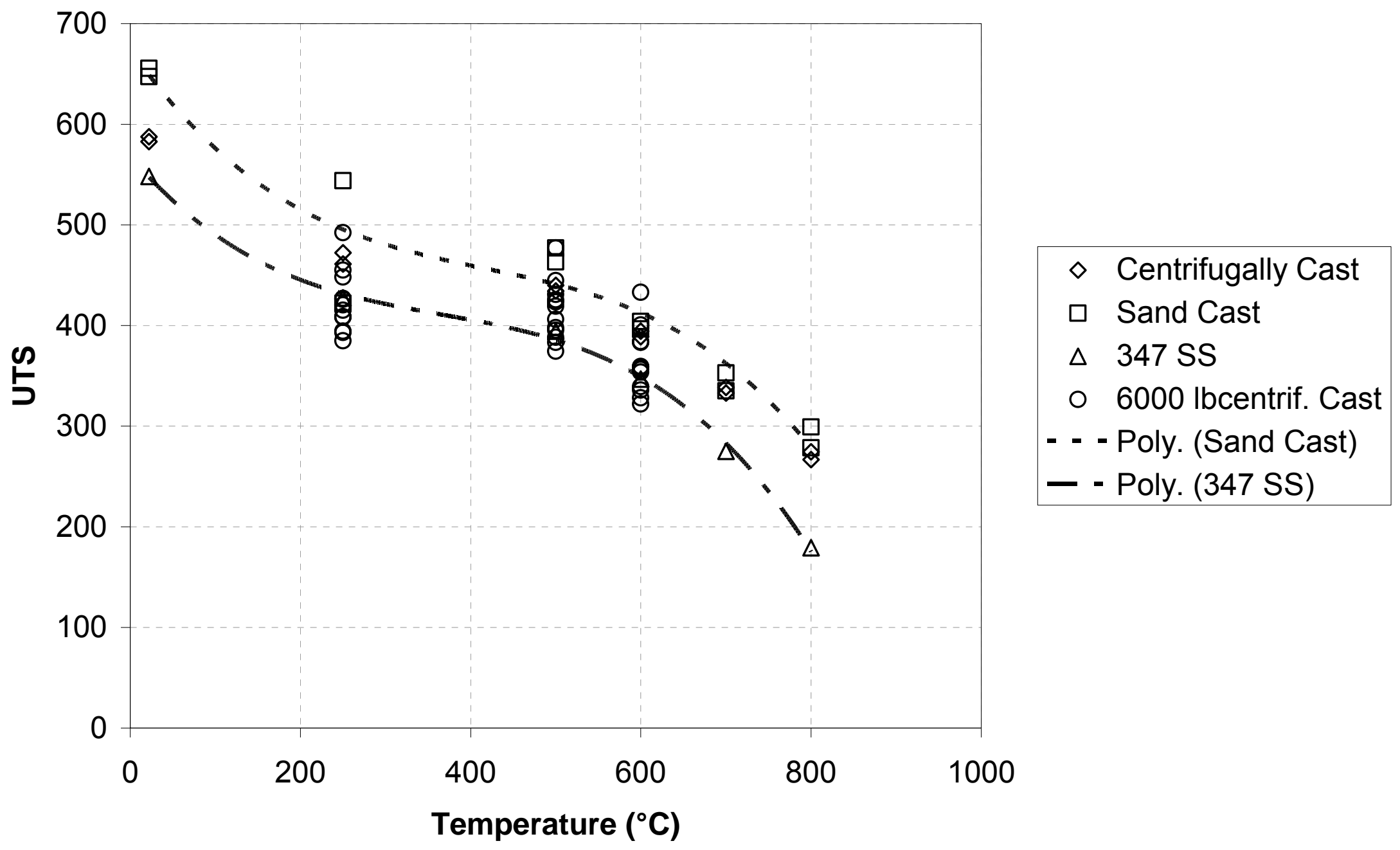

Figure 19. Ultimate tensile stress comparison for the two alloys. On a like-for-like basis, the CF8C+ outperforms $3475 S$. 


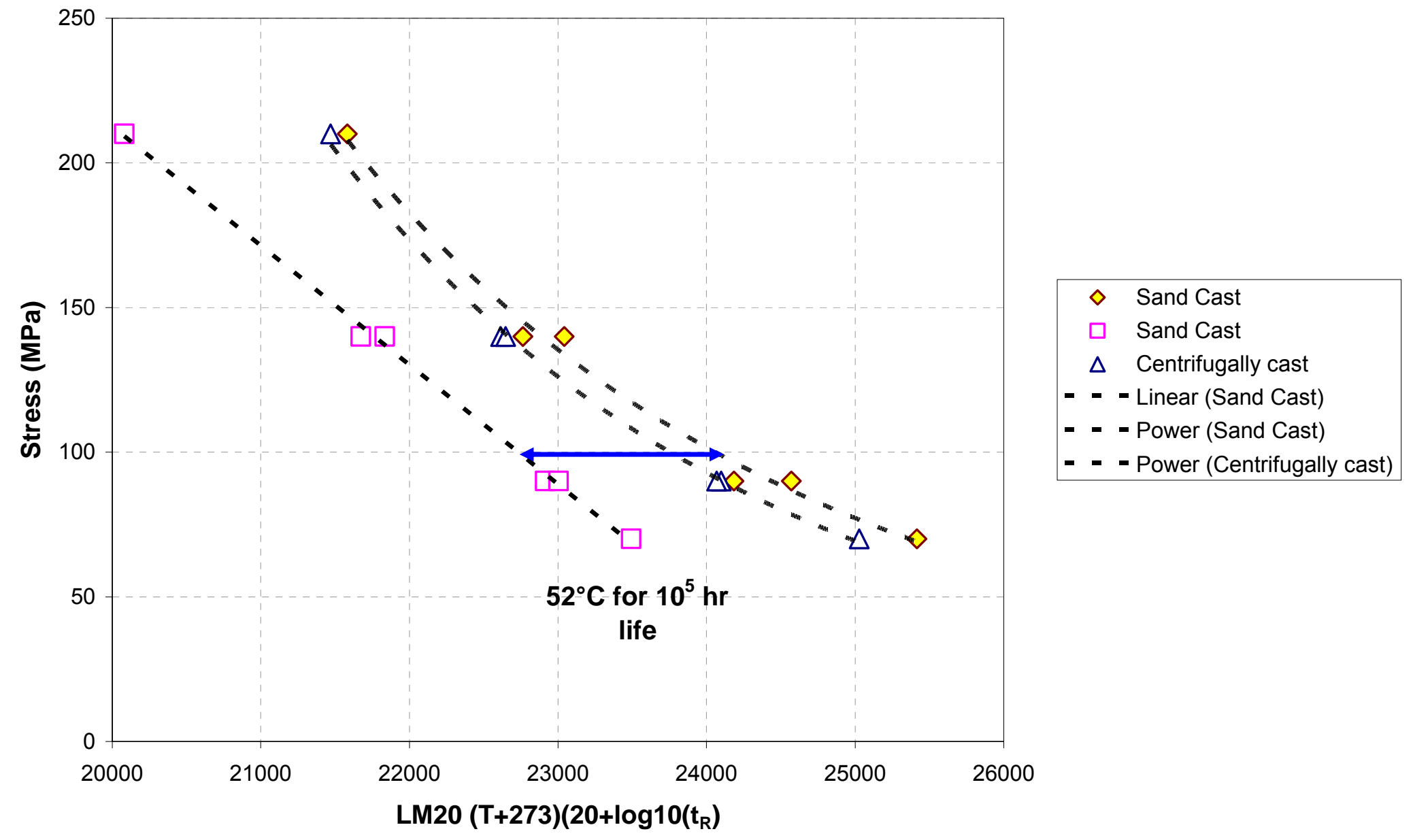

Figure 20. Larson Miller creep comparison for the two alloys. On a like-for-like basis, the CF8C+ outperforms $3475 S$. 


\section{ROADMAPS FOR MATERIALS R\&D ACTIVITY}

\subsection{Requirements}

For the two major component types, namely rotor components and casings, a full analysis of the desired mechanical properties has been carried out for Siemens design turbines. These requirements at $760^{\circ} \mathrm{C}\left(1400^{\circ} \mathrm{F}\right)$, define the needs which the materials technology to be developed has to achieve if an uncooled $760^{\circ} \mathrm{C}\left(1400^{\circ} \mathrm{F}\right)$ turbine is to be manufactured. The requirements are summarized in Table 4 . The technologies required and the costs and timescales are shown in the Narratives in the appendices. These are intended to provide a guide to the cost and timescale involved in developing the required technology.

\subsection{HP Rotors}

The rotor is probably the most challenging component in the entire turbine. Even if cooling steam were run through the bore, the lack of blade cooling means that cooling of the disk rim region would be difficult. In gas turbines, blade rims are cooled by the air which is fed into the turbine blades. Such a design is probably not practical in a steam turbine. Consequently, the rim of the rotor will be running at steam temperature. To provide a comparison, modern commercial aero-engines run with blade rim temperatures which reach $720^{\circ} \mathrm{C}\left(1328^{\circ} \mathrm{F}\right)$ only during takeoff. The peak temperature is typically attained by the disk for a total of around $100 \mathrm{hrs}$ during the entire life of the engine. The requirement here is to run hotter far in excess of 1000x longer than the aero-engines. Nevertheless, it is still feasible to produce rotors capable of surviving these conditions provided processing technology is pushed beyond its current limits.

To hold the cost down, the most realistic rotor design consist of a ferritic rotor stub at the cold end of the rotor connected to probably 4-5 nickel disks of varying complexity. Following the trends in ferritic materials, it appears unlikely that temperature capabilities exceeding $650^{\circ} \mathrm{C}$ will be achieved within the next $15-20$ years with current processing techniques. There is one process which does show promise, the optimization of the thermomechanical treatment of the nitrogen-bearing alloys to refine the nitride and carbide particles on the nano scale. The use of particles within the sub $10 \mathrm{~nm}$ size range for hardening promises to provide another $25^{\circ} \mathrm{C}\left(45^{\circ} \mathrm{F}\right)$ or more in creep capability over the conventionally processed material.

Solution strengthened nickel alloys have already been shown to be capable of providing sufficient strength for disks operating at up to $700^{\circ} \mathrm{C}\left(1292^{\circ} \mathrm{F}\right)$. Entire rotor forgings of sufficient size for both HP and IP turbine operation have been manufactured. The challenge comes in producing disks to operate above this temperature. The most commonly used particle strengthened Ni disk alloys in industrial gas turbines, IN 718 and IN 706, are both microstructurally unstable at such high temperatures and are thus not suitable. Of the high performance aero engine alloys, many can only be produced by isothermal forging processes due to their extreme high temperature mechanical properties. Isothermal forging of such alloys is currently limited to disks up to $900 \mathrm{~mm}$ (36"). Consequently, the roadmap for future materials differs between IP rotors (which are larger than this size) and HP rotors, for which the disks needed can be manufactured today. Though the disks can be manufactured, the material properties of such large disks have not been characterized, consequently mechanical characterization of rotors would be necessary, as would the development of joining technology for connecting 
them to the lower strength materials. Given funding, it would be realistic to say that a demonstrator HP turbine rotor could be designed in 5 years as shown in Figure 21.

To avoid segregation issues, powder technology would be the preferred route for billet formation. This would eliminate any segregation and simultaneously allow control of the grain size. There is, however, a risk of oxide contamination, so Non-destructive testing (NDT) would be even more critical than with current alloys. The biggest challenge would be in welding the rotor disks. Bolted disks would not be the preferred option due to the extreme pressures. Steam leakage would rapidly cause crevice corrosion in bolted configurations. Due to the difficulty of welding alloys with high aluminum level (Figure 22), a combination of mechanical interlocking and welding would be required. Filler-less welding routes such as electron beam welding and friction welding are the most likely to succeed, though friction welding would not be possible in conjunction with interlocking. To push the temperature envelope further advance processing would be needed. For the $760^{\circ} \mathrm{C}\left(1400^{\circ} \mathrm{F}\right)$ requirement, the disk alloy IN 100 would provide the required strength.

\subsection{IP Rotors}

As discussed in 9.2, producing rotor disks of sufficient size and strength for IP turbines is a major hurdle. Isothermal forging of the strongest alloys is currently not realistic, and would certainly require major investment to become so. Consequently novel approaches to the problem of disk fabrication must be looked at. Three are considered here, direct HIP to near-net-shape, dual microstructure disks and dual alloy disks.

\subsubsection{Direct HIP}

This is a process by which powdered alloy is compacted into a form close to the final component shape under high temperatures $\left(>1100^{\circ} \mathrm{C} / 2000^{\circ} \mathrm{F}\right)$ and pressures $(>100$ $\mathrm{MPa} / 15 \mathrm{ksi}$ ). This would allow larger components, but increases the risk of failures due to oxide impurities in the powders. This method is routinely used in Russian aeroengines, but only for short-lived components. Component sizes of up to $1.3 \mathrm{~m}$ (52") diameter and $3 \mathrm{~m}$ (120") long, weighing up to 13.6 tonnes $(30,000 \mathrm{lb})$ are possible ${ }^{12}$, so in principle entire rotor sections could be made. However, the risk of rogue oxides in the component would be high, and there would be difficulties in applying conventional lifing methodologies. In the Russian engine all disks are simply discarded after short periods of time and replaced.

\subsubsection{Dual Microstructure Disks}

If the strongest conventionally forged alloys are used, then the strength requirement can be met provided that the microstructure is optimized for creep. However, this requires a compromise in the fatigue properties of the disk bore. This ideal situation can be produced by a localized heat treatment process. This would be a super-solvus heat treatment on the disk rim to increase the grain size, combined with a sub-solvus one at the bore to retain the yield strength and fatigue life. Two methods to produce such a structure are feasible. Firstly, by zone heating of the disk: this could be carried out either by induction heating with different field intensities at the rim and bore, or by heating in a conventional furnace with localized cooling of the rim.

The strongest disk alloy that can be conventionally forged is Udimet $720 \mathrm{LI}$. Udimet 720 was originally developed as a blade alloy and used in a fully solutioned condition. The 
heat treatment was later modified to increase the ductility and thus permit forging allowing its use as a disk alloy with sub-solvus heat treatment. A subsequent development of the alloy reduced the levels of interstitial elements ( $B$ and $C$ ) as well as that of $\mathrm{Cr}$ to remove the known alloy instability problems ${ }^{13}$. As this alloy has heat treatments optimized for both tensile and creep strength, it is ideally suited to the task.

A second method of producing a dual structure disk relies on the on the difficulty of growing grains beyond prior particle boundaries (PPBs) in powder alloys. The PPBs are effectively the initial powder size. By manufacturing a disk of two different powder sizes, a dual microstructure can be produced, optimizing the properties. This processing could be carried out by a number of routes, for example co-forging a billet consisting of a ring of coarse grained material around a bore of fine grained alloy.

\subsubsection{Dual Alloy Disks}

The next step in disk design from a dual microstructure one is a disk in which the alloy composition at the rim differs from that in the bore. This is not a conventional processing route, but has been performed on a number of developmental projects, most notably the European BiMetal and Mandate projects in which Siemens participated in the 1990s. In this project a cast rim was produced first, filled with powder which was subsequently forged into the rim to form the bore of the disk. This technique allows the use of high creep strength cast superalloys to be used without compromising the tensile strength of the forged alloys which is needed at the bore. In the disk sizes considered here, casting inhomogeneity would probably produce too much variability in the rim properties to be useful. This is particularly due to the rim dimensions, which greatly exceed the blade sizes for which these alloys were developed.

\subsubsection{Turbine Blades}

Steam turbine blades are conventionally made from forged bar stock or near-net-shape forgings due to the flexibility of steam turbine designs. As each individual turbine is tuned to the customer's requirements, the blading configuration varies from one engine to the next. A consequence of this is that the use of cast blades is not feasible, as a new mould would have to be designed for each individual engine. This restriction would also apply to USC turbines, eliminating the option of using high strength cast blades directly. This leaves us with the choice of forged or HIPed powder blades. For the temperature requirements that we have for this engine, it leaves us, as with the HP rotor, with the high strength forgeable blade alloys such as Udimet 720 and IN 100 in the short term (Figure 24). In the longer term, HIP compaction of powdered blading alloys will allow further temperature improvements, exceeding the requirements for the target engine.

As the first one or two blade stages are unlikely to change significantly from engine to engine if a relatively fixed engine design is used, then it may be possible for these to be cast. If so, then the introduction of directionally solidified blade alloys, such as CM247DS would give creep performance sufficient for temperatures up to $875^{\circ} \mathrm{C}\left(1600^{\circ} \mathrm{F}\right)$ when oxidation coatings are applied.

For lower temperature regions, the use of solution strengthened nickel-based alloys and nano-particle strengthened steels will be adopted, in the same manner as for turbine disks (see p32). 


\subsubsection{Turbine Vanes}

For turbine vanes, a similar technology requirement exists to that for blades, and the solutions are similar (Figure 25).

\subsubsection{Coatings}

Materials used in the power plant should withstand creep and steam oxidation, while increasing the steam operating temperatures. The featured material should possess both creep and steam oxidation resistance, along with ease of fabrication. Along with these requirements, modern steam turbine components experience damage caused by the impact of small solid particles entrained in the gas or liquid stream.

Solid particle erosion of steam path surfaces has been a major concern in thermal power plants. This is mainly due to the formation of magnetite, an oxide of iron, on the inside of steam generator-ferritic alloy tubes, headers and steam lines exposed to high steam temperature. This builds up to a certain level and after further operation, it cracks and spalls, being brittle in nature. This magnetite breaks into angular particles and erodes all components in the steam path. The erosion damages are the most severe in areas where steam velocities are the highest and are commonly seen at the inlet or where reheated steam reenters the blade path. Identification of erosion-prone area of a steam turbine blading depends upon the flow characteristics such as its separation, reattachment and boundary layer growth.

In the past, extensive studies of solid particle erosion have been made, mainly at room temperature. Many parameters are now known to influence erosion behavior. The velocity of impinging particles influences the erosion rate considerably. The impingement angle is another important factor, with the maximum erosion rate occurring for ductile materials at sharp impingement angles of about $20^{\circ}-30^{\circ}$ and for brittle materials at normal impingement. Particle properties such as size, hardness and shape and particle concentration are also influencing factors. The erosion rate, of course, depends on the target materials. Temperature may also be an influencing factor. Since particle-erosion is a function of other parameters such as particle size, concentration, impingement angle and hardness of base material, in most cases it can only be improved by providing a protective hard coating on the erosion-prone areas.

Thermal sprayed cermet and metallic coatings are often used to resist severe wear in diverse industrial applications as mining, mineral or pulp and paper processing, aerospace and automobile manufacturing, and power generation. The ability of a coating to protect base materials against erosion depends upon its composition and microstructure, and its overall structural integrity. In turn, these are dependent on starting material composition and processing.. Whilst it has been reported that uniformly deposited and coherent coatings can provide erosion protection, many of the factors which control the rate of erosion, such as particle velocity, number of particles impacting a surface and their angle of impingement can be largely determined by the flow conditions of the system.

The advent of high velocity oxygen-fuel (HVOF) thermal spray has made a significant impact on the field, producing dense, well-adhered and more homogenous deposits of metals and cermets, due mainly to the combination of higher kinetic energy and lower spray temperatures. The HVOF process is an enhancement of combustion spraying, in 
which, a compressed flame undergoes free expansion upon exiting the torch nozzle, thereby experiencing dramatic gas acceleration. By axially injecting the feedstock powder, the particles are also subjected to a high acceleration to supersonic velocities. As a result, upon impacting the substrate, they spread out thinly to form dense coatings with low degrees of decomposition which are well bonded to the substrate. Also, owing to the high kinetic energy acquired by the powder particles, the process allows producing carbide based coatings and ensures a good cohesion with a minimum porosity and decarburization.

The present program involves a Design of experiments (DOE) approach to address the erosion and steam oxidation resistance for steam turbine components. The focus will be to utilize the potential of HVOF coating technology to deposit dense adherent coatings to meet the defined CTQs. The steps involve identification of materials compositions and evaluating the properties/performance of these coatings. Once the optimal coating performance is obtained, steps will be carried out to address the robustness of the process.

\subsection{Casings}

With the increased pressures and temperatures in a USC turbine, higher temperature casing alloys are required. To mitigate the cost of adoption of nickel-based alloys, the use of cooling may be employed along with TBC coatings. However, cooling reduces the engine efficiency and thus should be avoided if economically feasible.

The Thermie program in Europe looked at the use of IN 625 and IN 617 for castings, producing large scale sand castings in both alloys. It is considered that, with TBC coatings, these alloys will probably be sufficient for the even higher temperatures needed for the DOE specified turbines. Full characterization and alloy data generation is however needed, as the European programs only looked at demonstrating the feasibility of casting these alloys in large scale components.

The risk with this philosophy is that the properties of large scale sand cast IN 625 and IN 617 may be significantly lower than those of small scale precision cast material. If so, then higher strength alloys may need to be selected. As with the two current candidates, the alloys selected are likely to be ones which are currently used for forged applications. The candidates that would be reasonable to look at are IN 740 and Haynes 282. Both of these materials exhibit creep strength in excess of the current candidates in wrought form. Neither has been tested in cast form. Beyond these alloys we come to ones that have very high $\mathrm{y}^{\prime}$ levels, which are not readily weldable and do not have high enough ductility to deal with the massive thermal stresses that the casings undergo.

\subsection{Bolting}

Typical alloys for bolting applications clearly have to have high creep strength, but stress-corrosion cracking is also a critical requirement. Typically bolts are routinely tightened to compensate for stress relaxation. Even though the bolts in a USC turbine will not be exposed to the same high temperatures as the rest of the components, the temperature requirements will be higher than today. Since the steam pressure in these USC engines is far higher than in conventional subcritical and supercritical engines, the bolt strength is a critical requirement to avoid steam leakage. 
New wrought superalloys such as Haynes 282 and IN740 greatly exceed the creep strength of traditional bolting materials such as Refractalloy 26 and Nimonic $80 \mathrm{~A}$. For example Haynes 282 has a creep strength advantage of $90^{\circ} \mathrm{C}\left(195^{\circ} \mathrm{F}\right)$ for a typical bolting application. In terms of tensile behavior, it exceeds Refractalloy 26 by over $250^{\circ} \mathrm{C}$ $\left(482^{\circ} \mathrm{F}\right)$. 
Table 4. Material requirements for USC Steam turbine design

\begin{tabular}{|c|c|c|c|}
\hline Property & Component & $\begin{array}{l}\text { Minimum Requirements (SI Units) at } \\
760^{\circ} \mathrm{C} \text { unless otherwise stated }\end{array}$ & $\begin{array}{l}\text { Minimum Requirements (English } \\
\text { Units) at } 1400^{\circ} \mathrm{F} \text { unless otherwise } \\
\text { stated }\end{array}$ \\
\hline $\begin{array}{l}\text { Creep Rupture strength } \\
\text { at } 100,000 \text { hrs }\end{array}$ & Casing & $80 \mathrm{MPa}$ & $13.1 \mathrm{ksi}$ \\
\hline $\begin{array}{l}\text { Ultimate Tensile } \\
\text { Strength }\end{array}$ & Casing & $300 \mathrm{MPa}$ & $43.5 \mathrm{ksi}$ \\
\hline \multirow[t]{2}{*}{ Yield Strength } & Rotor & $200 \mathrm{MPa}$ & $29.0 \mathrm{ksi}$ \\
\hline & Casing & $200 \mathrm{MPa}$ & $29.0 \mathrm{ksi}$ \\
\hline Poisson's ratio & Casing & $0.25<v 0.32$ & $0.25<v 0.32$ \\
\hline Material Form & Rotor & Forging & Forging \\
\hline
\end{tabular}


Table 4 (continued). Material requirements for USC Steam turbine design

\begin{tabular}{|c|c|c|c|}
\hline Property & Component & $\begin{array}{l}\text { Minimum Requirements (SI Units) at } \\
760^{\circ} \mathrm{C} \text { unless otherwise stated }\end{array}$ & $\begin{array}{l}\text { Minimum Requirements (English } \\
\text { Units) at } 1400^{\circ} \mathrm{F} \text { unless otherwise } \\
\text { stated }\end{array}$ \\
\hline \multirow[t]{2}{*}{ Welding } & Rotor & $\begin{array}{l}\text { Weldable to the same material, weldable } \\
\text { to } 10 \% \mathrm{Cr} \text { steel. Weld strength equal to } \\
\text { base metal strength of } 10 \% \text { at } 600^{\circ} \mathrm{C} \text {. }\end{array}$ & $\begin{array}{l}\text { Weldable to the same material, weldable } \\
\text { to } 10 \% \mathrm{Cr} \text { steel. Weld strength equal to } \\
\text { base metal strength of } 10 \% \text { at } 1112^{\circ} \mathrm{F}\end{array}$ \\
\hline & Casing & $\begin{array}{l}\text { Weldable to same material at same } \\
\text { strength as base alloy }\end{array}$ & $\begin{array}{l}\text { Weldable to same material at same } \\
\text { strength as base alloy }\end{array}$ \\
\hline \multirow[t]{2}{*}{ Inspectability } & Rotor & Detect $2 \mathrm{~mm}$ flaw & Detect $0.079 "$ flaw \\
\hline & Casing & Inspectable using x-ray technology & Inspectable using x-ray technology \\
\hline Erosion resistance & $\begin{array}{l}\text { All steam path } \\
\text { components }\end{array}$ & $\begin{array}{l}\text { Steam erosion and wear resistance } \\
\text { similar to } 10 \% \mathrm{Cr} \text { steels @ } 600^{\circ} \mathrm{C}\end{array}$ & $\begin{array}{l}\text { Steam erosion and wear resistance } \\
\text { similar to } 10 \% \mathrm{Cr} \text { steels @ } 1112^{\circ} \mathrm{C}\end{array}$ \\
\hline \multirow{2}{*}{$\begin{array}{l}\text { Coefficient of thermal } \\
\text { expansion }\end{array}$} & Rotor & $<16 \times 10^{-6} \mathrm{~K}^{-1}$ & $<8.89 \times 10^{-6}{ }^{\circ} \mathrm{F}^{-1}$ \\
\hline & Casing & $<16 \times 10^{-6} \mathrm{~K}^{-}$ & $<8.89 \times 10^{-6}{ }^{\circ} \mathrm{F}^{-1}$ \\
\hline
\end{tabular}


Table 4 (continued). Material requirements for USC Steam turbine design

\begin{tabular}{|c|c|c|c|}
\hline Property & Component & $\begin{array}{l}\text { Minimum Requirements (SI Units) at } \\
760^{\circ} \mathrm{C} \text { unless otherwise stated }\end{array}$ & $\begin{array}{l}\text { Minimum Requirements (English } \\
\text { Units) at } 1400^{\circ} \mathrm{F} \text { unless otherwise } \\
\text { stated }\end{array}$ \\
\hline \multirow[t]{3}{*}{ Component Dimensions } & HP Rotor & $700 \mathrm{~mm}$ diameter & 27.5" diameter \\
\hline & IP Rotor & $1000 \mathrm{~mm}$ diameter & 39.5" diameter \\
\hline & Hot part length & $1000-1500 \mathrm{~mm}$ & $39,5-59 "$ \\
\hline
\end{tabular}




\section{HP Turbine Rotor Materials Capability \\ (Uncooled or minimal cooling)}

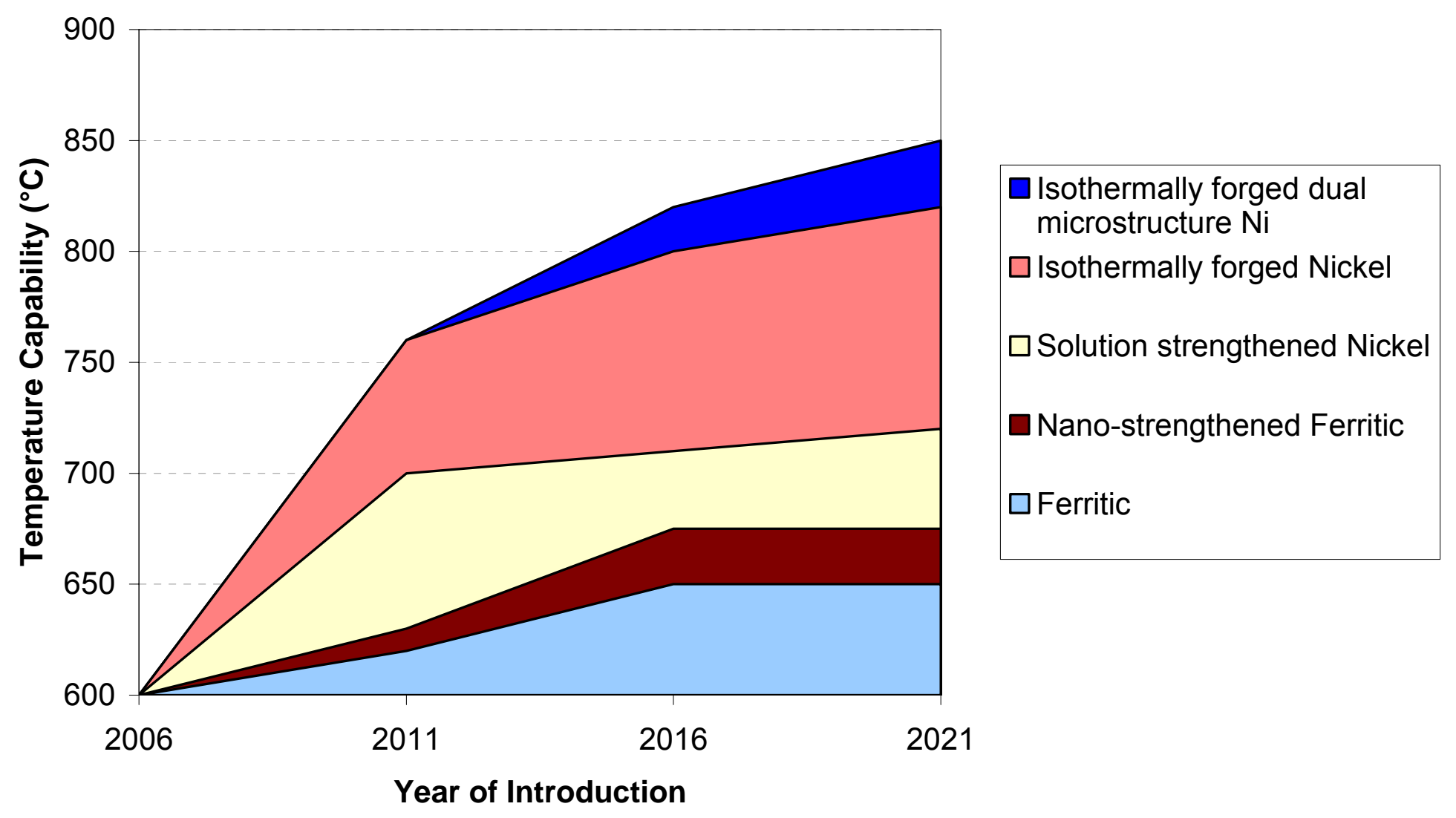

Figure 21. Roadmap for High Pressure Rotor Materials 
Weldability per Al-Ti content

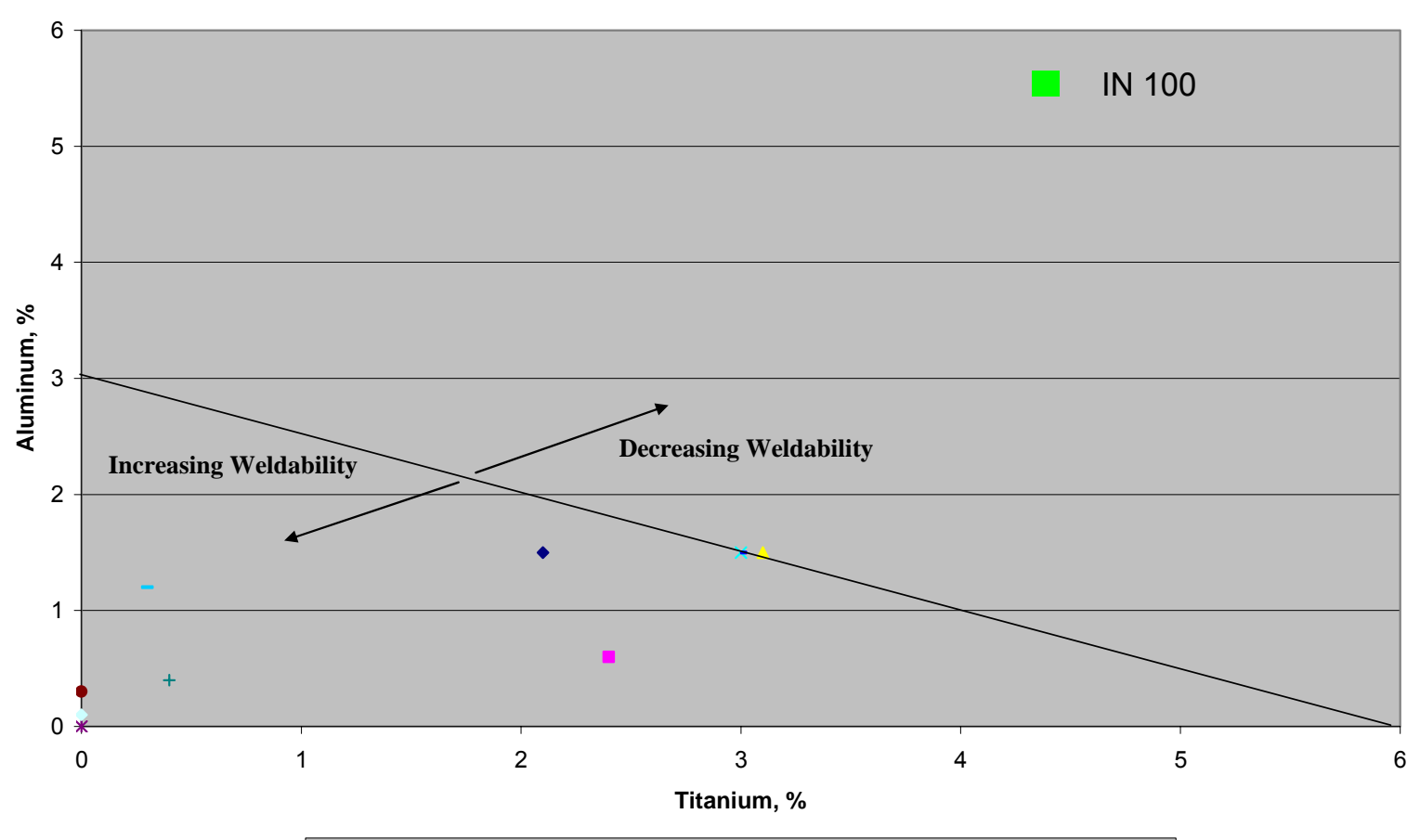

- $282 \approx 263 \triangle$ R-41 Waspaloy $* 188 \bullet 230+625-$ Hastelloy X $-617 \bullet 120$

Figure 22. Schematic of alloy weldability against aluminum and titanium levels in the parent alloy showing the difficulty of welding IN 100 


\section{IP Turbine Materials Rotor Capability (Uncooled or minimal cooling)}

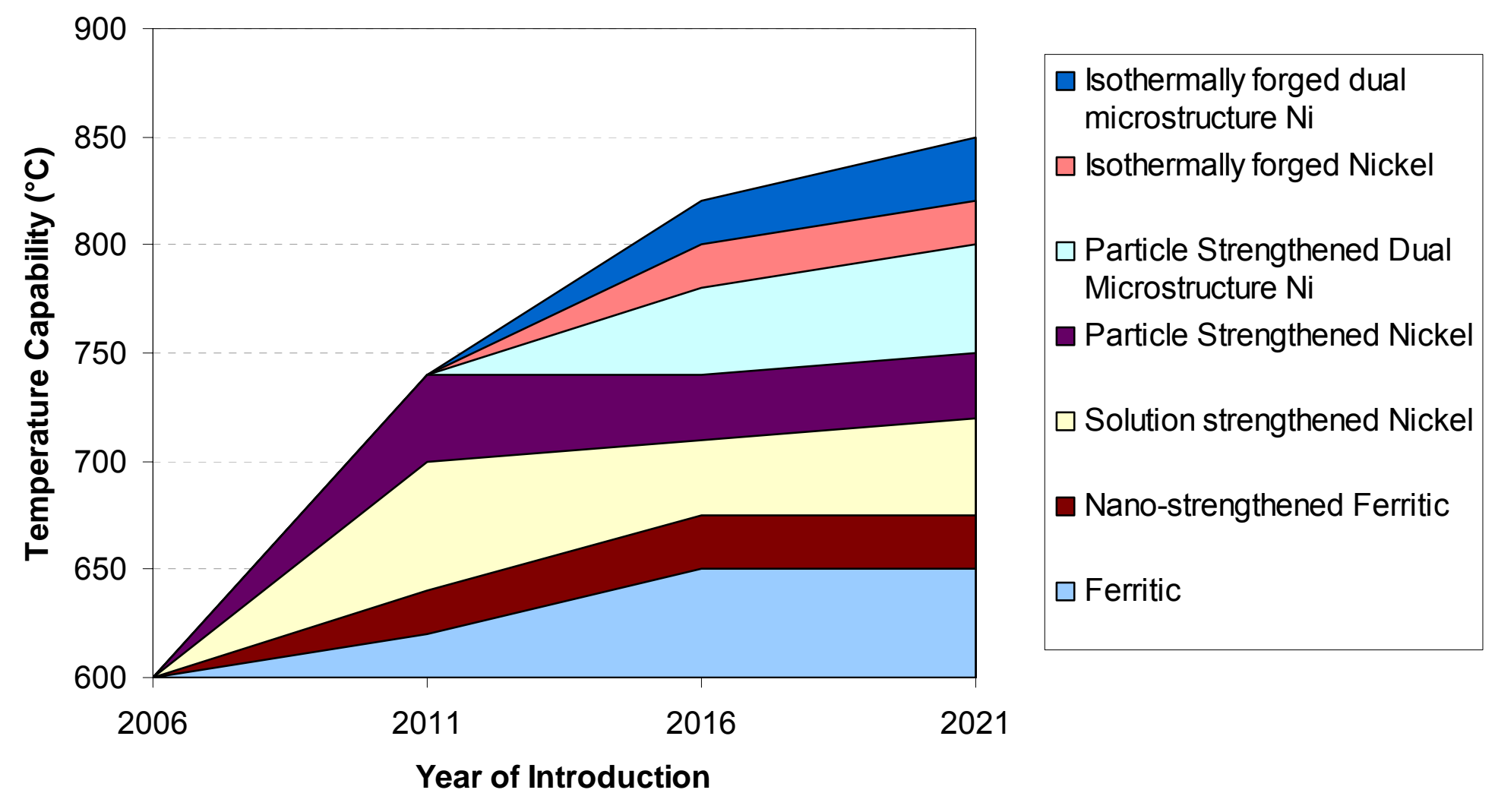

Figure 23. Roadmap for Intermediate Pressure Rotor Materials 


\section{Turbine Blade Materials}

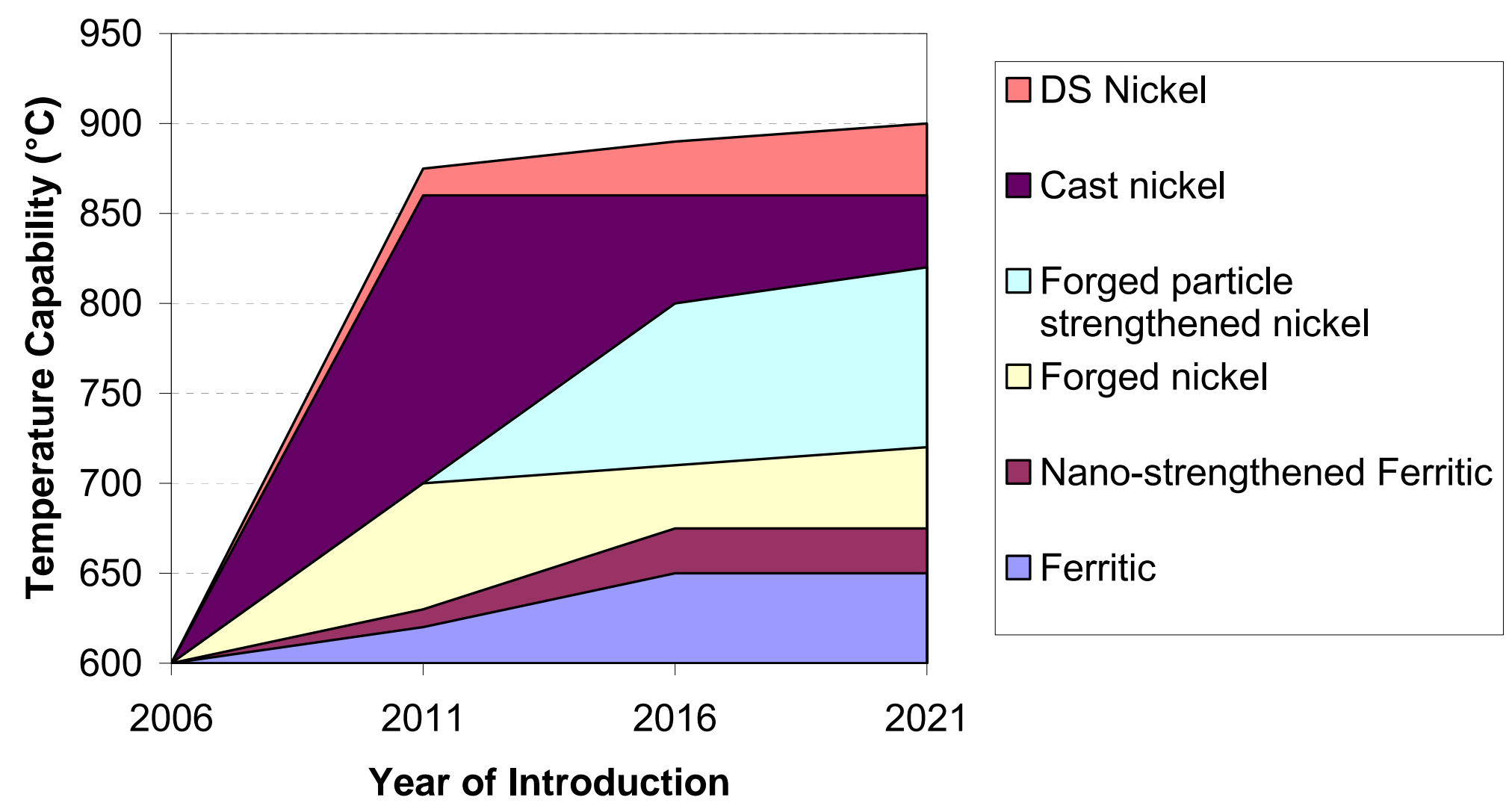

Figure 24. Roadmap for first stage turbine blade alloys (HP and IP) 


\section{Turbine Vane Materials}

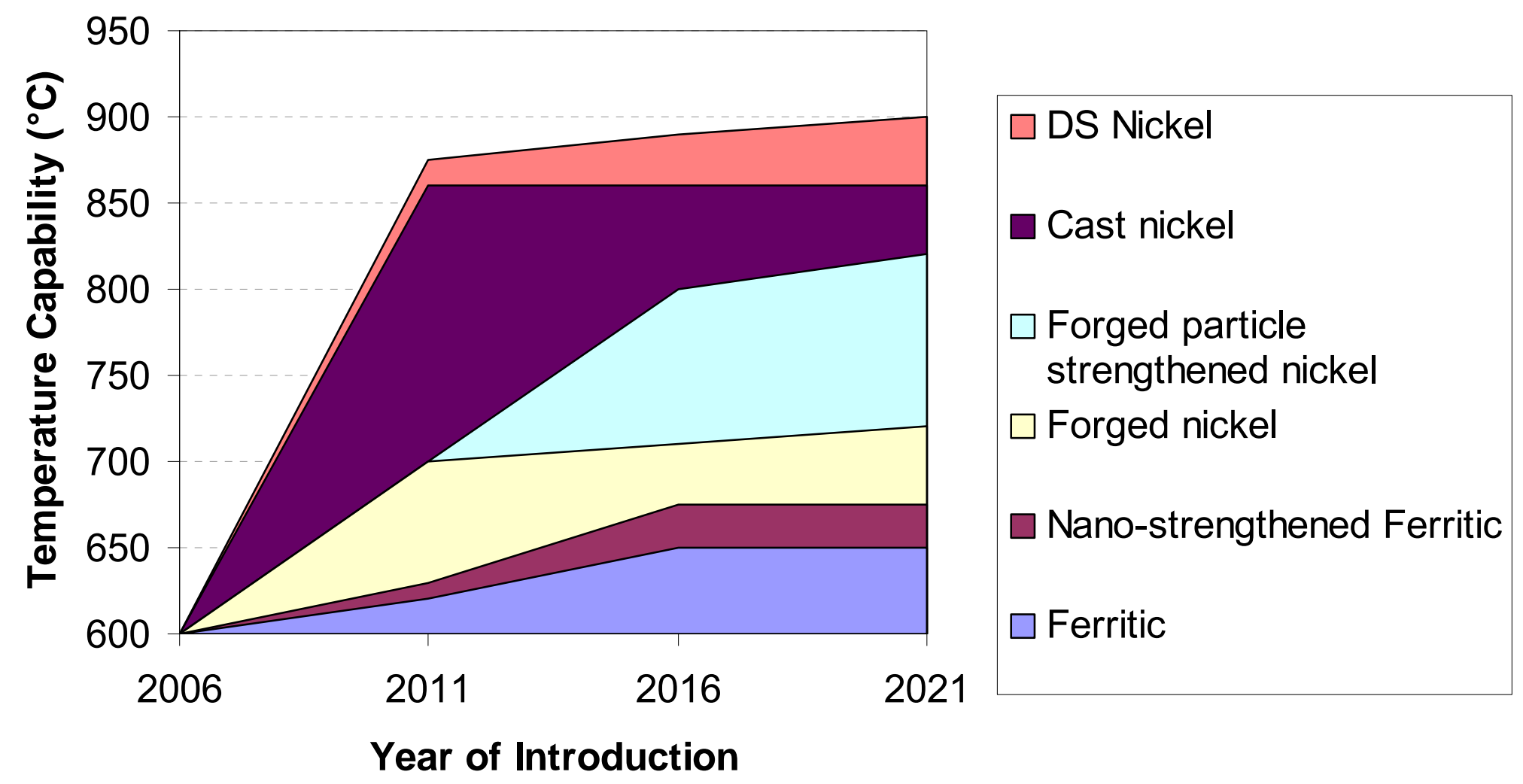

Figure 25. Roadmap for first stage turbine vane alloys (HP and IP) 


\section{Potential Erosion Resistant Coatings}

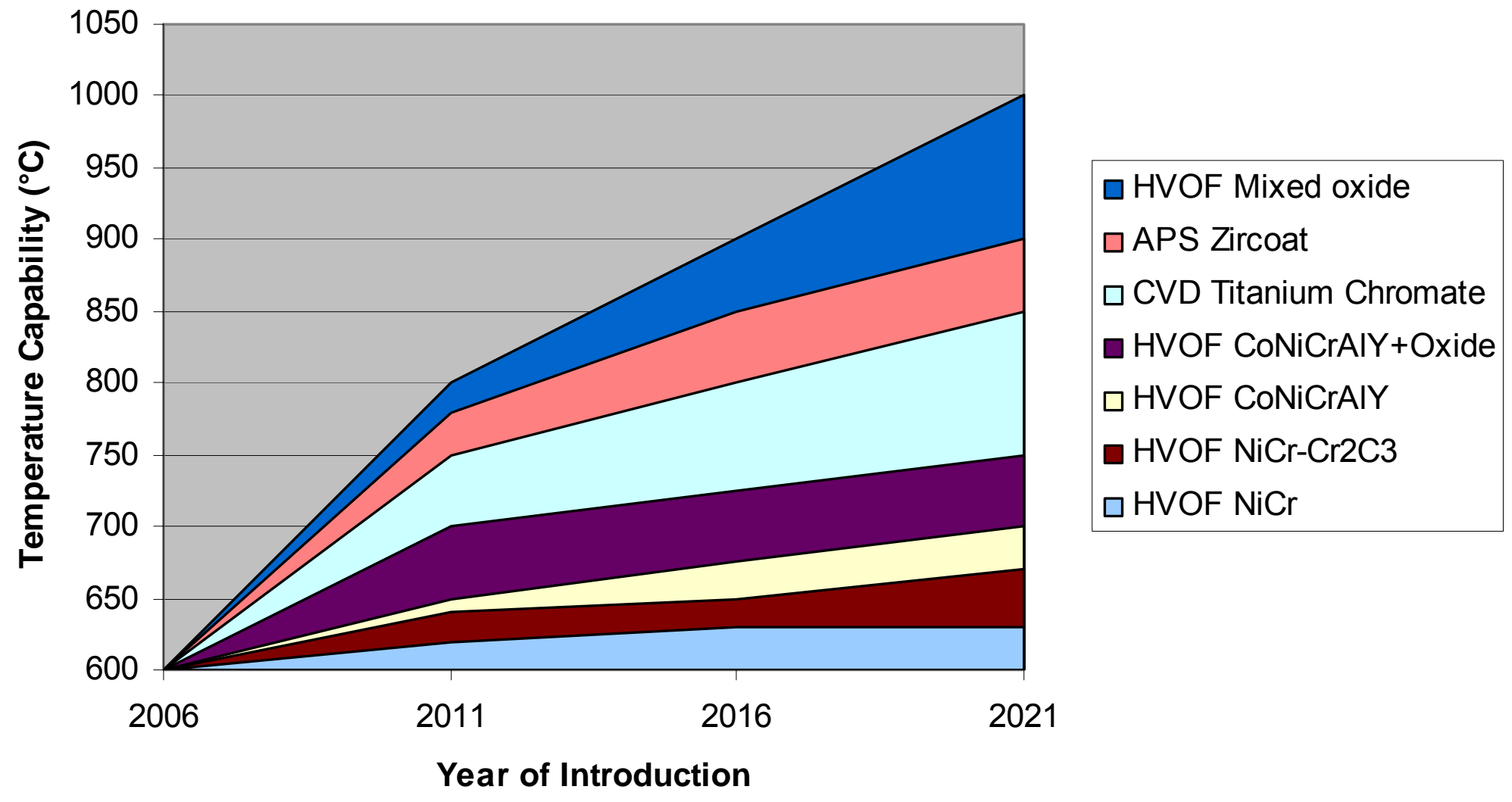

Figure 26. Roadmap of erosion and steam resistant coating development 


\section{Casing Materials}

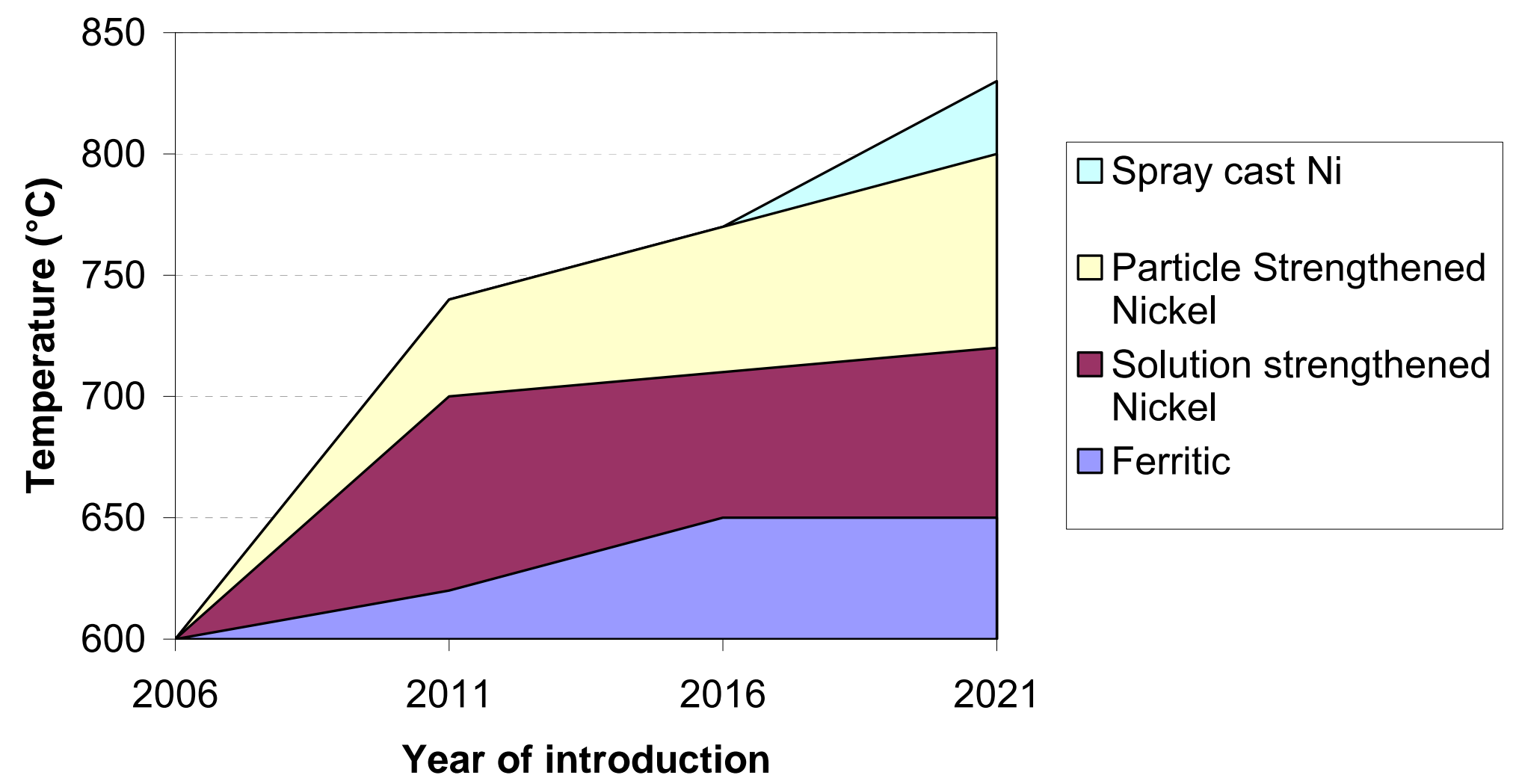

Figure 27. Roadmap for high temperature casing materials 


\section{SUMMARY OF FUTURE TURBINE USING ROADMAP MATERIALS DEVELOPMENTS}

The figures below show the materials used in today's $600^{\circ} \mathrm{C}$ turbines (Figure 28) with the proposed selections for a $760^{\circ} \mathrm{C}$ turbine (Figure 29)

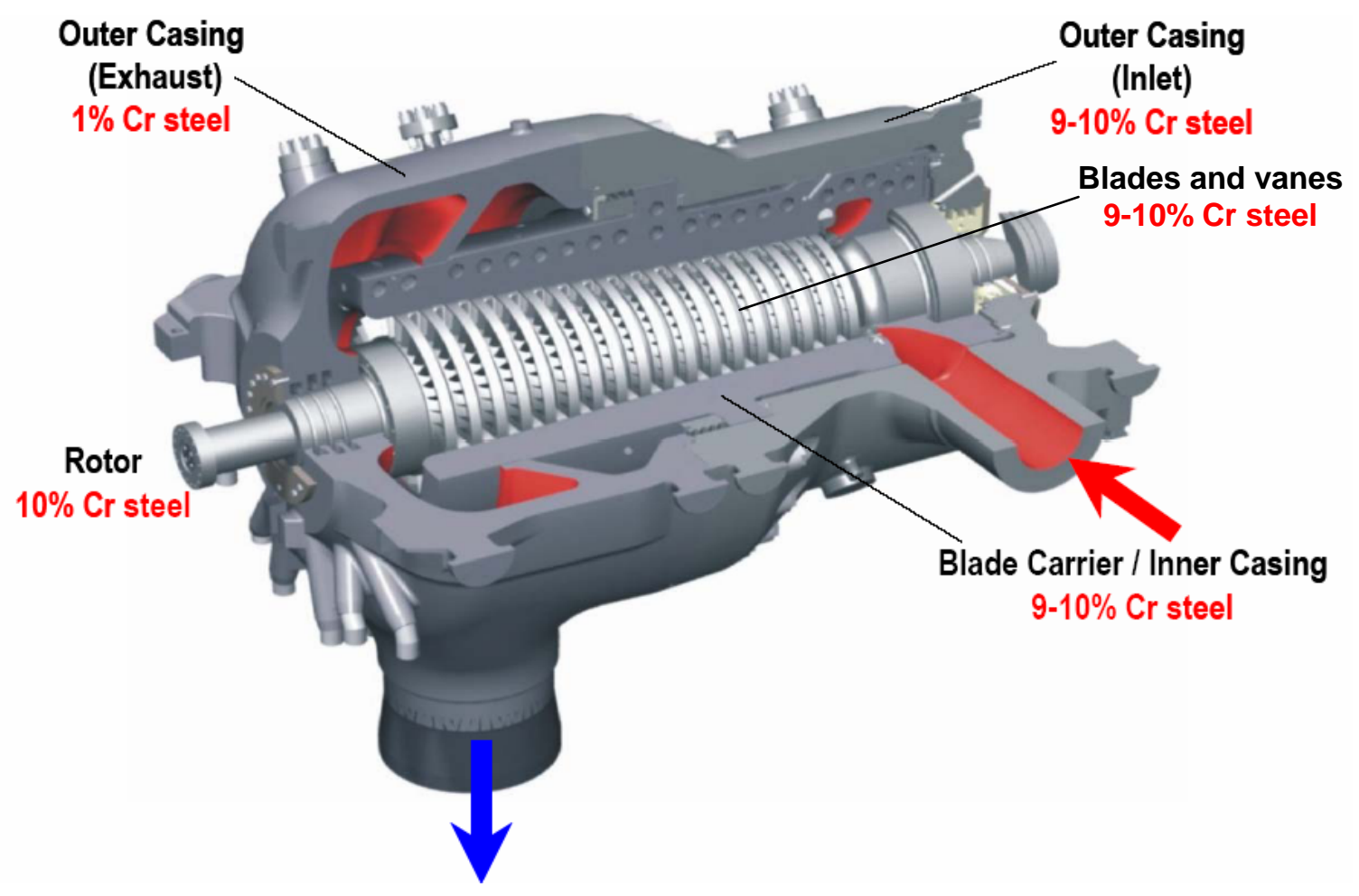

Figure 28. $600^{\circ} \mathrm{C}$ steam turbine materials selections 


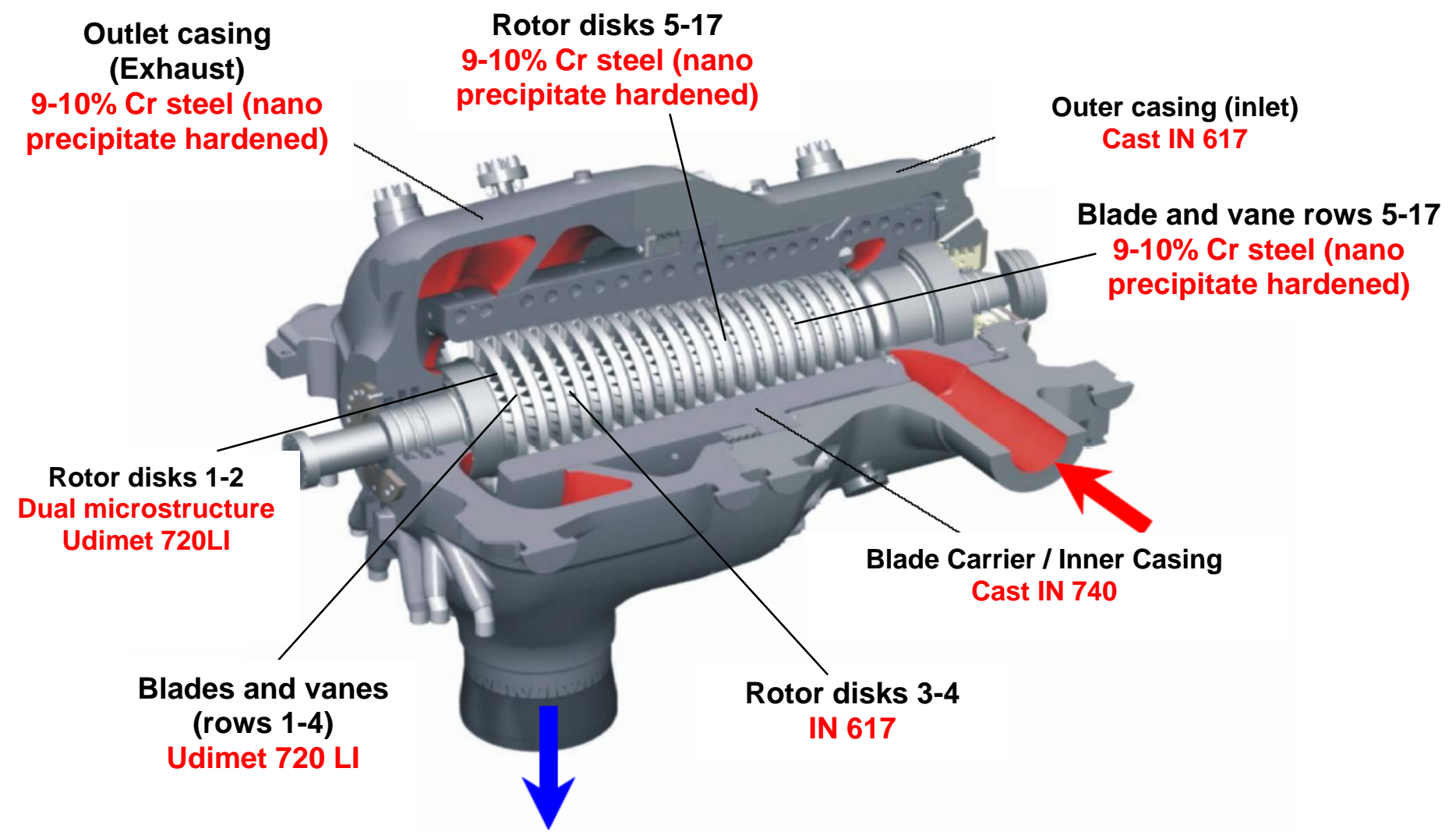

Figure 29. Possible $760^{\circ} \mathrm{C}$ steam turbine materials selections 


\section{APPENDICES: MATERIALS TECHNOLOGY NARRATIVES}

\subsection{Rotor materials - advanced processing of current alloys}

\subsubsection{Technical Barriers \& Research Approach:}

\begin{tabular}{|l|l|}
\hline $\begin{array}{l}\text { Technology \& Manufacturing Barriers \& } \\
\text { Risks }\end{array}$ & $\begin{array}{l}\text { Approach to Overcome the Technical } \\
\text { Issues/Barriers }\end{array}$ \\
\hline $\begin{array}{l}\text { Optimizing the mechanical processing for } \\
\text { Siemens alloys }\end{array}$ & $\begin{array}{l}\text { Thermodynamic modeling and deformation } \\
\text { modeling }\end{array}$ \\
\hline Design optimized alloys & $\begin{array}{l}\text { Thermodynamic modeling and deformation } \\
\text { modeling }\end{array}$ \\
\hline
\end{tabular}

\subsubsection{Benefit to Program:}

With the increased pressures and temperatures in a USC turbine, higher temperature rotor alloys are required. To mitigate the cost of adoption of nickel-based alloys, the operating temperature of ferritic steel rotors must be raised as high as possible.

Forged nickel based alloys such as IN100 and Udimet 720 will provide higher mechanical properties than ferritics, but would further increase the cost of the components. A higher temperature steel should be identified, which would be capable of being used in the required environment.

Current high temperature ferritic steels use nitrogen as an alloying addition. This produces a distribution of fine strengthening particles in the $30-50 \mathrm{~nm}$ scale, primarily vanadium nitride and niobium carbide, known collectively as MX particles, along with much larger conventional $\mathrm{M}_{23} \mathrm{C}_{6}$ carbides. Modifying the thermo/mechanical heat treatment of such steels has produced dramatic improvements on mechanical performance on laboratory scale tests. This treatment refines the size of the MX precipitates down to the $3-8 \mathrm{~nm}$ size range. This project aims to take current Siemens blade alloys, and apply the advanced processing routes to enhance properties without significantly increasing the component cost. The process refinement is applicable to a large range of nitrogen-doped martensitic steels, which are conventionally used for both blade and disk alloys.

Further improvements in performance will be available by optimizing the steels by raising the vanadium and niobium levels to boost the formation of MX particles. 


\subsubsection{Testing and Validation:}

- Modeling of process for current alloys

- Initial trials on coupons

- Trial pancake forging (disks)

- Mechanical tests on forged materials - tensile, creep, Icf, fracture toughness, crack growth

- Rotor forging and further mechanical tests

- Selection of candidate alloys

- Modeling of process for selected alloys

- Initial trials on coupons

- Mechanical tests and downselect

- Mechanical tests on forged materials - tensile, creep, Icf, fracture toughness, crack growth

- Rotor forging and further mechanical tests

\subsubsection{GO/NO GO Key Decision Points}

\begin{tabular}{|l|l|}
\hline Date & Decision to be Made \\
\hline 6 months & $\begin{array}{l}\text { Does the improved processing give } \\
\text { significant property improvements }\end{array}$ \\
\hline 18 months & $\begin{array}{l}\text { Is the cost of the selected process } \\
\text { economic? }\end{array}$ \\
\hline 30 Months & $\begin{array}{l}\text { Are any of the new compositions } \\
\text { significantly better than current alloys? }\end{array}$ \\
\hline
\end{tabular}


11.1.5 Key Milestones \& Deliverables (internal and external, both)

\begin{tabular}{|l|l|}
\hline Date & Deliverable \\
\hline 6 months & Complete modeling of process \\
\hline 12 months & $\begin{array}{l}\text { Small-scale coupons of current alloys } \\
\text { forged }\end{array}$ \\
\hline 24 months & $\begin{array}{l}\text { New alloy composition matrix defined and } \\
\text { alloys ordered }\end{array}$ \\
\hline 30 months & Alloys Forged \\
\hline 36 months & Optimal alloy selected \\
\hline 48 months & $\begin{array}{l}\text { Improved process mechanical data } \\
\text { available for base alloys }\end{array}$ \\
\hline 102 months & Mechanical data available for new alloys \\
\hline
\end{tabular}




\subsection{Nickel-base rotors}

\subsubsection{Technical Barriers \& Research Approach:}

\begin{tabular}{|l|l|}
\hline $\begin{array}{l}\text { Technology \& Manufacturing Barriers \& } \\
\text { Risks }\end{array}$ & $\begin{array}{l}\text { Approach to Overcome the Technical } \\
\text { Issues/Barriers }\end{array}$ \\
\hline Optimizing forging processes & $\begin{array}{l}\text { Thermodynamic modeling and deformation } \\
\text { modeling }\end{array}$ \\
\hline Design optimized alloys & $\begin{array}{l}\text { Thermodynamic modeling and deformation } \\
\text { modeling }\end{array}$ \\
\hline
\end{tabular}

\subsubsection{Benefit to Program:}

With the increased pressures and temperatures in a USC turbine, higher temperature rotor alloys are required. At temperatures exceeding $650^{\circ} \mathrm{C}$, it is generally agreed that ferritic materials are unlikely to be applicable, unless there is a significant change in their design. Such changes do not appear to be on the horizon. To mitigate the cost of adoption of nickel-based rotor they must be welded to ferritic rotor sections so as to only use them at the temperatures at which the nickel alloys are needed.

Forged particle strengthened nickel based alloys such as IN100 and Udimet 720 will provide higher mechanical properties than solution strengthened alloys, but would further increase the cost of the components. To reach $760^{\circ} \mathrm{C}$ with minimal component cooling, the highest temperature stages will not be solution strengthened.

Components in superalloys capable of use in steam turbine rotors up to $700^{\circ} \mathrm{C}$ have been demonstrated in Europe by Saarschmide, though these have not been used. Such capabilities are available in Europe and Japan. American forge masters are not known to have the capability to forge such rotors. As smaller sections will be required for $760^{\circ} \mathrm{C}$ use due to the higher temperature gradient from front to back planned for such engines, these large rotor blocks may not be needed. Disks or bi-disk sections would be suitable. Reliable welding of rotor sections to ferritics and precipitation strengthened alloys has not been demonstrated. To further push the envelope, improved material compositional control would be needed, in the manner that has been applied to IN 617 when CCA 617 was developed from it. 


\subsubsection{Testing and Validation:}

- Already demonstrated for current alloys. Process qualification would be needed

- Selection of alloy for improvement.

- Statistical regression analysis of delivery data for alloys to identify the parameters to be tightened and modified.

- Production of multiple heats of trial material in improved alloy

- Mechanical properties

- Scale up to full-sized forging.

\subsubsection{GO/NO GO Key Decision Points}

\begin{tabular}{|l|l|}
\hline Date & Decision to be Made \\
\hline 12 months & $\begin{array}{l}\text { Does analysis indicate that a significant } \\
\text { improvement in properties is possible }\end{array}$ \\
\hline 36 Months & $\begin{array}{l}\text { Is the tightened spec significantly better } \\
\text { than the current alloy? }\end{array}$ \\
\hline
\end{tabular}

\subsubsection{Key Milestones \& Deliverables (internal and external, both)}

\begin{tabular}{|l|l|}
\hline Date & Deliverable \\
\hline 12 months & Complete modeling of process \\
\hline 24 months & Small-scale coupons of alloys forged \\
\hline 42 months & Small scale mechanical tests \\
\hline 48 months & Large scale alloys forging \\
\hline 102 months & Mechanical data available for new alloy \\
\hline
\end{tabular}




\subsection{Welding of Udimet 720 and Inconel 617}

\subsubsection{Summary}

Inconel 617 (IN617) is a commonly welded alloy for power generation applications. Udimet 720LI (U720LI) combines high strength with good oxidation and corrosion resistance, which is useful for gas turbines. This alloy acquires strength from both solid solution strengthening and precipitation hardening. The $y^{\prime}$ precipitates formed from Aluminum and Titanium in the base material prove problematic to weldability. Considerations for joining of the dissimilar material combination (U720LI and IN617) and the autogenous process (U720LI to itself) are arc, high energy density and solid state processes.

\subsubsection{Technical Barriers \& Research Approach:}

\begin{tabular}{|l|l|}
\hline $\begin{array}{l}\text { Technology \& Manufacturing Barriers \& } \\
\text { Risks }\end{array}$ & $\begin{array}{l}\text { Approach to Overcome the Technical } \\
\text { Issues/Barriers }\end{array}$ \\
\hline Limited welding data & $\begin{array}{l}\text { Various testing procedures } \\
\text { Arc, high energy density and solid state } \\
\text { processes are being considered }\end{array}$ \\
\hline Weldability & $\begin{array}{l}\text { Varestraint testing } \\
\text { Design of experiments } \\
\text { Destructive and nondestructive testing }\end{array}$ \\
\hline
\end{tabular}

\subsubsection{Benefit to Program:}

The usage of nickel based superalloys in gas turbine applications is attributed to the material characteristics at high temperatures. These desirable material characteristics are problematic for welding. The fine gamma prime ( $\left.\mathrm{Y}^{\prime}\right)$ precipitates $\left(\mathrm{Ni}_{3} \mathrm{Al}, \mathrm{Ni}_{3} \mathrm{Ti}\right)$ strengthen the alloy. However, these precipitates in part dissolve at peak temperatures and coarsen in areas such as the heat affected zone (HAZ). The welds undergo post weld heat treatment (PWHT) and aging to form the fine grain structure similar to the base material and to relieve stresses. The re-precipitation during PWHT strengthens the alloy, but the softer coarse grains remain within the HAZ.

The stress relief is difficult, since it is attained by creep and plastic deformation. The precipitates of nickel based superalloys promote high creep resistance and low creep ductility. The coarse grains take the ownership of the stress relief since the fine grain matrix is incapable. Cracking can initiate along the coarse grain boundaries and propagate throughout the weldment. This phenomenon is known as strain age cracking. Strain age cracking is also service-related, since the material is continuously "heat 
treated" and cooled.

Since aluminum and titanium in addition to nickel are the key elements to forming Y', Figure 1 provides the weldability based on susceptibility to cracking. Although IN617 has good weldability in comparison to the critical line, U720LI is not as favorable. U720LI to U720LI will be very difficult to weld as well as U720LI to IN617.

Weldability per Al-Ti content

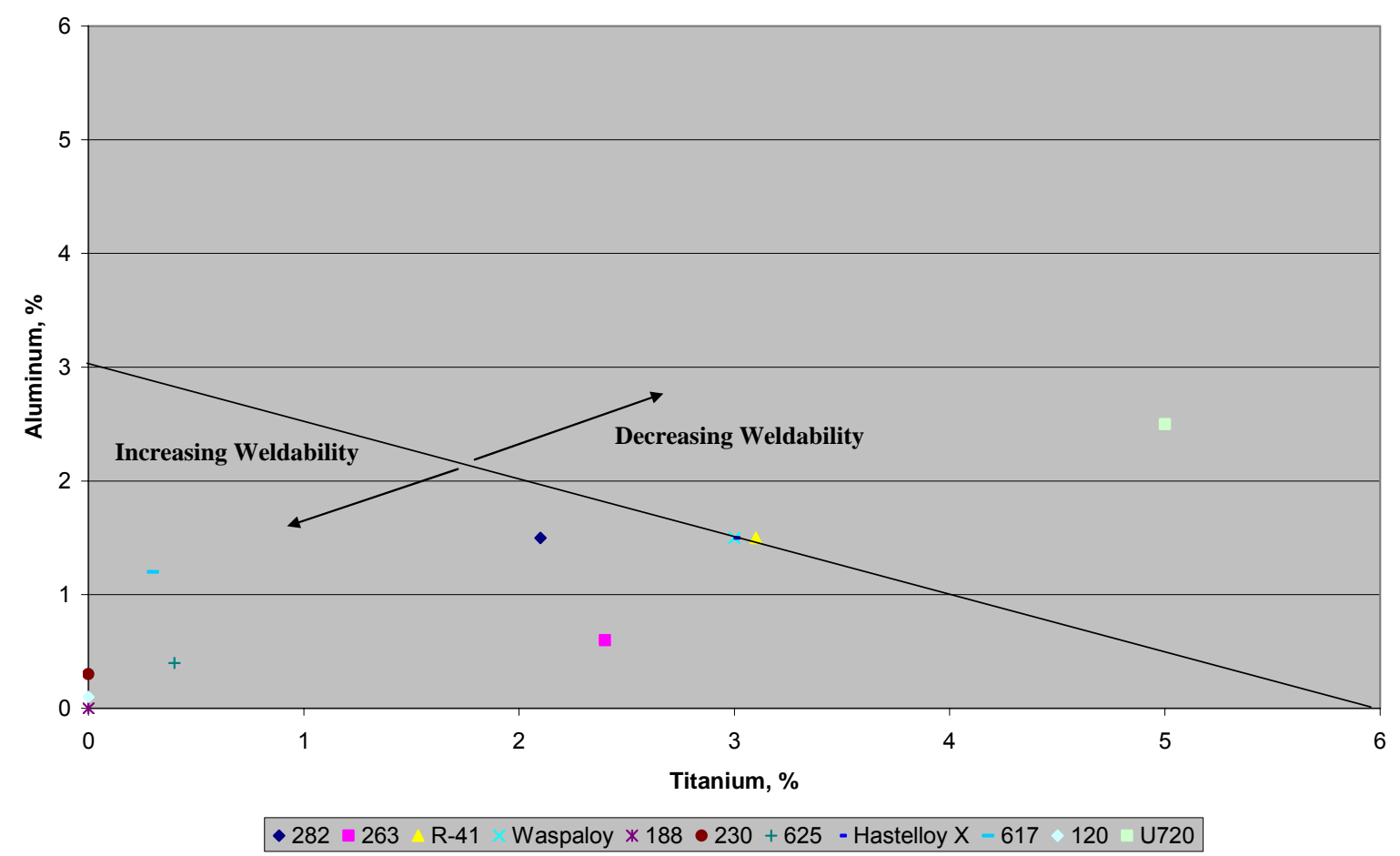

Figure 30. Weldability per Al-Ti content.

In addition to strain age cracking, hot cracking can be difficult to control in alloys containing interstitial elements such a silicon, zirconium and boron. These elements have been added to intentionally promote material properties such as high temperature strength. However, the elements contain lower melting point eutectics. These interstitial elements cause the grain boundary to melt at a temperature lower than the material matrix (grain boundary liquation). The minimized strength along this grain boundary allows the material to separate or fissure. Thus, a crack is initiated within the material. 


\subsubsection{Testing and Validation:}

- Varestraint test(s) - material sensitivity to cracking

- Design of experiments, multiple joining operations - characterization of material operating region(s)

- Nondestructive and destructive test(s) - evaluation of microstructure and defect(s); analysis of weldment properties in comparison to operating parameters

\subsubsection{GO/NO GO Key Decision Points}

\begin{tabular}{|l|l|}
\hline Date & Decision to be Made \\
\hline 8 months & $\begin{array}{l}\text { Based on preliminary data, which alloy(s) } \\
\text { are less susceptible to cracking? }\end{array}$ \\
\hline
\end{tabular}

\subsubsection{Key Milestones \& Deliverables (internal and external, both)}

\begin{tabular}{|l|l|}
\hline Date & Deliverable \\
\hline 4 months & Samples fabricated for welding \\
\hline 4 months & Varestraint testing complete \\
\hline 10 months & Vendor weld qualification \\
\hline 24 months & $\begin{array}{l}\text { Destructive/nondestructive testing } \\
\text { complete }\end{array}$ \\
\hline
\end{tabular}




\subsection{Isothermally Forged nickel-base rotors}

\subsubsection{Technical Barriers \& Research Approach:}

\begin{tabular}{|l|l|}
\hline $\begin{array}{l}\text { Technology \& Manufacturing Barriers \& } \\
\text { Risks }\end{array}$ & $\begin{array}{l}\text { Approach to Overcome the Technical } \\
\text { Issues/Barriers }\end{array}$ \\
\hline Optimizing forging processes & $\begin{array}{l}\text { Thermodynamic modeling and deformation } \\
\text { modeling }\end{array}$ \\
\hline
\end{tabular}

\subsubsection{Benefit to Program:}

With the increased pressures and temperatures in a USC turbine, higher temperature rotor alloys are required. At temperatures exceeding $650^{\circ} \mathrm{C}$, it is generally agreed that ferritic materials are unlikely to be applicable, unless there is a significant change in their design. Such changes do not appear to be on the horizon. To mitigate the cost of adoption of nickel-based rotor they must be welded to ferritic rotor sections so as to only use them at the temperatures at which the nickel alloys are needed.

Forged particle strengthened nickel based alloys such as IN100 and Udimet 720LI will provide higher mechanical properties than solution strengthened alloys, but would further increase the cost of the components. To reach $760^{\circ} \mathrm{C}$ capability, only the strongest disk alloys would be suitable without advanced dual microstructure forging or cast disk rims.

To use such alloys, of which IN 100 is the most well known example, conventional forging is not suitable, due to cracking as the temperatures of the disk rims drop. To be able to forge such alloys, isothermal forging is required. This is a process by which the forging is carried out at a fixed temperature in a vacuum. As the forge plates cannot be cooled, refractory alloys are required, which oxidize rapidly in air.

Extremely large isothermal forges are rare, and to date no disks in the size required for the IP turbine have been manufactured.

An additional problem with such alloys is that they are very prone to partitioning issues, i.e. segregation of elements within the initial billet. With very large billets, such as those that would be required for IP turbine disks, it is possible that the segregation issue would not be resolvable within a reasonable timeframe or cost. Consequently it is intended that the initial billets would be produced by powder compaction. This has the disadvantage that there is a higher potential for oxide entrainment, but guarantees the homogeneity of the billet. 


\subsubsection{Testing and Validation:}

- Already demonstrated for current alloys. Process qualification would be needed

- Selection of alloy for improvement.

- Statistical regression analysis of delivery data for alloys to identify the parameters to be tightened and modified.

- Production of multiple heats of trial material in improved alloy

- Mechanical properties

- Scale up to full-sized forging.

\subsubsection{GO/NO GO Key Decision Points}

\begin{tabular}{|l|l|}
\hline Date & Decision to be Made \\
\hline 12 months & $\begin{array}{l}\text { Does analysis indicate that a significant } \\
\text { improvement in properties is possible }\end{array}$ \\
\hline 36 Months & $\begin{array}{l}\text { Is the tightened spec significantly better } \\
\text { than the current alloy? }\end{array}$ \\
\hline
\end{tabular}

\subsubsection{Key Milestones \& Deliverables (internal and external, both)}

\begin{tabular}{|l|l|}
\hline Date & Deliverable \\
\hline 12 months & Complete modeling of process \\
\hline 24 months & Small-scale coupons of alloys forged \\
\hline 42 months & Small scale mechanical tests \\
\hline 48 months & Large scale alloys forging \\
\hline 102 months & Mechanical data available for new alloy \\
\hline
\end{tabular}




\subsection{High Temperature Disc Materials}

\subsubsection{Technical Barriers \& Research Approach:}

\begin{tabular}{|c|c|}
\hline $\begin{array}{l}\text { Technology \& Manufacturing Barriers \& } \\
\text { Risks }\end{array}$ & $\begin{array}{l}\text { Approach to Overcome the Technical } \\
\text { Issues/Barriers }\end{array}$ \\
\hline $\begin{array}{l}\text { Disc temperatures of up to } 760^{\circ} \mathrm{C} \text { are } \\
\text { predicted in the mid-term engine concept. } \\
\text { Such disc temperatures will demand the } \\
\text { use of the latest nickel base alloys (e.g. } \\
\text { U720Li, RR1000). Although such alloys } \\
\text { are widely used in aero engines, the scale- } \\
\text { up to the sizes (approx. } 1100 \mathrm{~mm} \text { ) required } \\
\text { for the ZEST will be challenging. }\end{array}$ & $\begin{array}{l}\text { The alloy U720Li has a composition which } \\
\text { is at the limit for processing via a cast / } \\
\text { wrought route. Higher strength alloys } \\
\text { would require manufacture via a powder } \\
\text { metallurgy route. These alloys will need to } \\
\text { be forged via an isothermal or isocon } \\
\text { (isothermal + conventional) process. }\end{array}$ \\
\hline $\begin{array}{l}\text { Grain size has a dramatic effect on the } \\
\text { properties. A large grain size is desired for } \\
\text { creep resistance and fatigue crack growth } \\
\text { resistance, while a fine grain size is } \\
\text { required for tensile strength and fatigue } \\
\text { crack initiation. It is difficult to achieve fine } \\
\text { grain sizes with cast/wrought product. It is } \\
\text { difficult to achieve grain sizes of larger } \\
\text { than ASTM } 4-5 \text { with - } 270 \text { mesh powder } \\
\text { due to prior particle boundaries. }\end{array}$ & $\begin{array}{l}\text { The use of an isocon processing route with } \\
\text { cast billet may have the capability to } \\
\text { increase grain size control. } \\
\text { The use of a larger power fraction (-150 } \\
\text { mesh) would support the formation of } \\
\text { larger grains. } \\
\text { The use of two size powder fractions (fine } \\
\text { in the bore \& diaphragm, coarse in the rim) } \\
\text { would support the manufacture of dual } \\
\text { microstructure discs. }\end{array}$ \\
\hline $\begin{array}{l}\text { Non-Destructive Evaluation (NDE) is } \\
\text { critical to ensure the integrity of disc } \\
\text { forgings. Techniques such as ultra sonic } \\
\text { inspection are highly sensitive to grain } \\
\text { size. }\end{array}$ & $\begin{array}{l}\text { NDE will form an integral part of disc } \\
\text { development. Special attention will be } \\
\text { given to the controlling codes for the } \\
\text { inspection of rotating components to } \\
\text { ensure that adequate inspection is } \\
\text { possible during the manufacture of the } \\
\text { discs. }\end{array}$ \\
\hline $\begin{array}{l}\text { The lifing of discs manufactured a powder } \\
\text { metallurgy route may differ to discs } \\
\text { manufactured via a more conventional } \\
\text { cast/wrought route. A probabilistic rather } \\
\text { than a deterministic approach may be } \\
\text { required. }\end{array}$ & $\begin{array}{l}\text { An assessment of powder cleanliness and } \\
\text { NDE inspectability will be made in } \\
\text { conjunction with an assessment of the } \\
\text { different lifing approaches to determine to } \\
\text { appropriate methods. }\end{array}$ \\
\hline $\begin{array}{l}\text { Disc temperatures of up to } 815^{\circ} \mathrm{C} \text { are } \\
\text { predicted in the far-term engine concept. } \\
\text { Such temperatures are probably beyond } \\
\text { the limits of currently available disc }\end{array}$ & $\begin{array}{l}\text { With the assumption that the bore/ } \\
\text { diaphragm of the disc can be cooled to } \\
\text { temperatures of around } 760^{\circ} \mathrm{C} \text {, a dual alloy } \\
\text { approach would be investigated for the }\end{array}$ \\
\hline
\end{tabular}




\begin{tabular}{|l|l|}
\hline materials. & $\begin{array}{l}\text { manufacture of } 815^{\circ} \mathrm{C} \text { rim temperature } \\
\text { capable discs. }\end{array}$ \\
\hline Steam effects on disc alloys & This will be assessed in sub-task ..... \\
\hline $\begin{array}{l}\text { The welding of the advanced disc alloys to } \\
\text { form rotors will be difficult. }\end{array}$ & $\begin{array}{l}\text { The weldability of U720LI is currently being } \\
\text { evaluated under the DOE funded USC } \\
\text { steam program (contact number: DE- } \\
\text { FC26-05NT42442) run jointly between } \\
\text { Siemens, GE and Alstom. Bolting may be } \\
\text { necessary }\end{array}$ \\
\hline
\end{tabular}

\subsubsection{Benefit to Program:}

To achieve disc temperatures of $760^{\circ} \mathrm{C}$ will require the introduction of nickel discs. $\mathrm{U} 720 \mathrm{Li}$ is finding widespread application in aero-turbines and is the alloy most likely to meet the balance between manufacturability and properties. U720Li can be processed via a cast + isothermal forging route, and can also be processed via the powder metallurgy route. Limitations on segregation in the cast billet would probably limit the maximum size of billet diameter to approximately $600 \mathrm{~mm}$ (24"). An alternative to cast/wrought processing would be to follow a powder metallurgy processing route. A powder billet of around $500 \mathrm{~mm}$ (20") diameter and $600 \mathrm{~mm}$ (24") high would be required for the manufacture of discs with a diameter of $1100 \mathrm{~mm}$. Such powder billet dimensions are within the capabilities of currently available HIP vessels. A further option would be to manufacture a powder perform to near-net shape to reduce the number of isothermal forging operations.

The adoption of the cast/wrought processing route may allow for forging via an isocon process, whereby the disc is initially isothermally forged and then final forged via conventional hammer. This approach could offer increased opportunity for control of the grain size.

Manufacture of the discs using powder metallurgy with a -270 mesh powder will yield a component with smaller grain size which is desirable for ultra sonic inspection, but may limit the final grain size to around ASTM 4-5 due the presence of prior particle boundaries. Starting with a coarser powder fraction (e.g. -150 mesh) would potentially reduce the inspectability but support the generation of a coarser grain size.

\subsubsection{Testing and Validation:}

There are a number of possible processing options for producing U720Li discs at the required size for the Zero Emissions Steam Turbine, and these are shown schematically in Figure 31. 

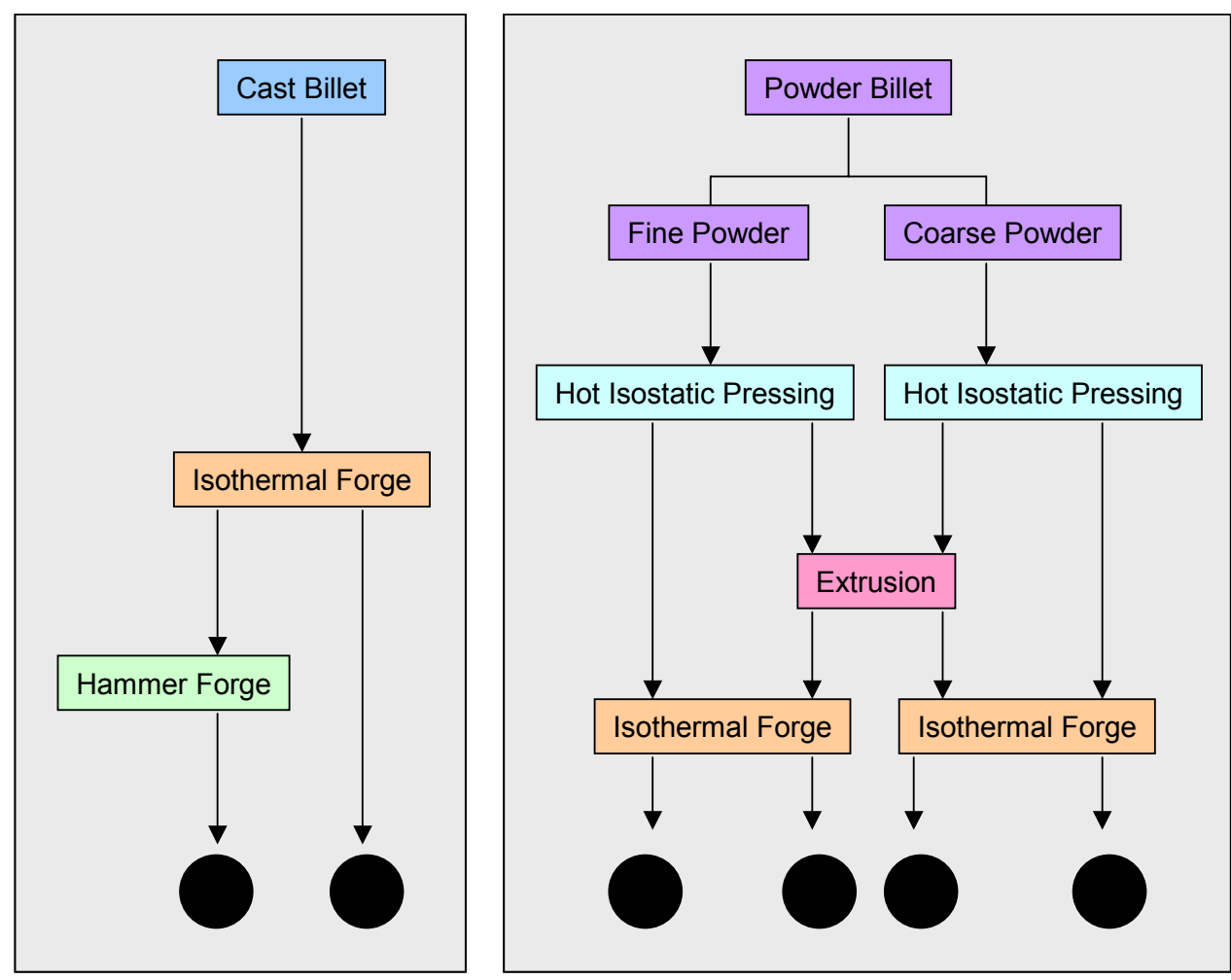

Figure 31. Potential processing routes for U720Li discs

In addition to the various options for manufacturing, there are a number of possibilities for heat treatment and post-heat treatment cooling. The heat treatment and cooling options are shown schematically in Figure 2.

The heat treatment schedule, cooling and prior processing will control the grain size, gamma prime size and residual stresses, which in turn will control the properties.

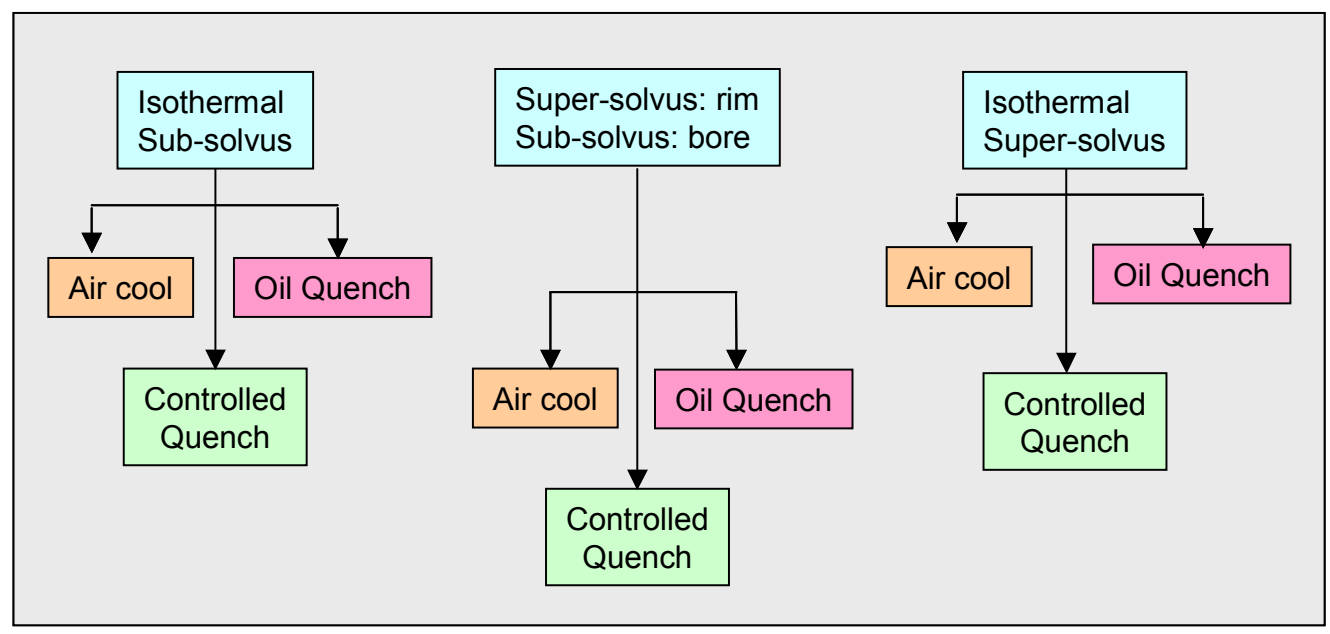

Figure 32. Heat treatment and cooling options 
At this initial stage, the proposal would be to manufacture three simple pancake forgings of approximately $600 \mathrm{~mm}$ (24" diameter).

- Cast billet - Isothermal + conventional hammer forge

- Fine Powder billet - HIP - Extrude - Isothermal forge

- Coarse powder - HIP - Isothermal forge

The forgings would then be sectioned into quarters to investigate the heat treatment parameters. Quarter size forgings will have sufficient mass and section sizes to remain representative of the full size forgings.

Non-Destructive Evaluation would be performed on the product at various stages throughout manufacture (billet, extrusion, post iso-forge and post conventional forge). The degree of inspectability will be used to help determine the appropriate manufacturing route.

Testing will be performed on the forgings to determine tensile, creep and fatigue properties. Microstructural evaluation will also be performed on the forgings to determine grain size, gamma prime size and the distribution of second phase particles. 


\subsubsection{GO/NO GO Key Decision Points}

\begin{tabular}{|l|l|}
\hline Date & Decision to be Made \\
\hline 3 months form start & $\begin{array}{l}\text { Can the required properties be generated } \\
\text { in the trial pancake forgings - can the } \\
\text { desired microstructures be produced? }\end{array}$ \\
\hline 3 months from start & Are products inspectable? \\
\hline
\end{tabular}

\subsubsection{Key Milestones \& Deliverables (internal and external, both)}

\begin{tabular}{|l|l|}
\hline Date & Deliverable \\
\hline 6 months from start & Cast billet available \\
\hline 7 months from start & Complete cast billet inspection \\
\hline 6 months from start & HIP billet available (fine powder) \\
\hline 8 months from start & HIP billet available (coarse powder) \\
\hline 9 months from start & Extrusion complete (fine powder) \\
\hline 9 months from start & Complete inspection of extrusion \\
\hline 15 months from start & First forging available \\
\hline 21 months from start & Second forging available \\
\hline 24 months from start & Third forging available \\
\hline 27 months from start & Complete inspection of forgings \\
\hline 30 months from start & Heat treatments complete \\
\hline 36 months from start & Complete post heat treatment inspections \\
\hline 40 months from start & Complete mechanical test evaluation \\
\hline
\end{tabular}




\subsection{Rotor blade materials - advanced processing of current alloys}

\subsubsection{Technical Barriers \& Research Approach:}

\begin{tabular}{|l|l|}
\hline $\begin{array}{l}\text { Technology \& Manufacturing Barriers \& } \\
\text { Risks }\end{array}$ & $\begin{array}{l}\text { Approach to Overcome the Technical } \\
\text { Issues/Barriers }\end{array}$ \\
\hline $\begin{array}{l}\text { Optimizing the mechanical processing for } \\
\text { Siemens alloys }\end{array}$ & $\begin{array}{l}\text { Thermodynamic modeling and deformation } \\
\text { modeling }\end{array}$ \\
\hline Design optimized alloys & $\begin{array}{l}\text { Thermodynamic modeling and deformation } \\
\text { modeling }\end{array}$ \\
\hline
\end{tabular}

\subsubsection{Benefit to Program:}

With the increased pressures and temperatures in a USC turbine, higher temperature blade alloys are required. To mitigate the cost of adoption of nickel-based alloys, the operating temperature of ferritic steel blades must be raised as high as possible.

Forged nickel based alloys such as IN100 and Udimet 720 will provide higher mechanical properties than ferritics, but would further increase the cost of the components. A higher temperature steel should be identified, which would be capable of being used in the required environment.

Current high temperature ferritic steels use nitrogen as an alloying addition. This produces a distribution of fine strengthening particles in the $30-50 \mathrm{~nm}$ scale, primarily vanadium nitride and niobium carbide, known collectively as MX particles, along with much larger conventional M23C6 carbides. Modifying the thermo/mechanical heat treatment of such steels has produced dramatic improvements on mechanical performance on laboratory scale tests. This treatment refines the size of the $\mathrm{MX}$ precipitates down to the $3-8 \mathrm{~nm}$ size range. This project aims to take current Siemens blade alloys, and apply the advanced processing routes to enhance properties without significantly increasing the component cost. The process refinement is applicable to a large range of nitrogen-doped martensitic steels, which are conventionally used for both blade and disk alloys.

Further improvements in performance will be available by optimizing the steels by raising the vanadium and niobium levels to boost the formation of MX particles. 


\subsubsection{Testing and Validation:}

- Modeling of process for current alloys

- Initial trials on coupons

- Trial extrusions (rods)

- Mechanical tests on forged materials - tensile, creep, Icf, fracture toughness, crack growth

- Selection of candidate alloys

- Modeling of process for selected alloys

- Initial trials on coupons

- Mechanical tests and downselect

- Mechanical tests on extruded materials - tensile, creep, Icf, fracture toughness, crack growth

\subsubsection{GO/NO GO Key Decision Points}

\begin{tabular}{|l|l|}
\hline Date & Decision to be Made \\
\hline 6 months & $\begin{array}{l}\text { Does the improved processing give } \\
\text { significant property improvements }\end{array}$ \\
\hline 30 months & $\begin{array}{l}\text { Is the cost of the selected process } \\
\text { economic? }\end{array}$ \\
\hline
\end{tabular}




\subsubsection{Key Milestones \& Deliverables (internal and external, both)}

\begin{tabular}{|l|l|}
\hline Date & Deliverable \\
\hline 6 months & Complete modeling of process \\
\hline 12 months & $\begin{array}{l}\text { Small-scale coupons of current alloys } \\
\text { forged }\end{array}$ \\
\hline 24 months & $\begin{array}{l}\text { New alloy composition matrix defined and } \\
\text { alloys ordered }\end{array}$ \\
\hline 30 months & Alloys Forged \\
\hline 36 months & Optimal alloy selected \\
\hline 48 months & $\begin{array}{l}\text { Improved process mechanical data } \\
\text { available for base alloys }\end{array}$ \\
\hline 102 months & Mechanical data available for new alloys \\
\hline
\end{tabular}




\subsection{Erosion resistant coatings}

\subsubsection{Technical Barriers \& Research Approach:}

\begin{tabular}{|l|l|}
\hline $\begin{array}{l}\text { Technology \& Manufacturing Barriers \& } \\
\text { Risks }\end{array}$ & $\begin{array}{l}\text { Approach to Overcome the Technical } \\
\text { Issues/Barriers }\end{array}$ \\
\hline $\begin{array}{l}\text { Coating system with necessary density } \\
\text { and erosion resistance }\end{array}$ & Selection of alloy compositions \\
\hline Coating adherence and steam oxidation & Process control for robust coatings \\
\hline
\end{tabular}

\subsubsection{Benefit to Program:}

Ultra super critical (USC) $\left(650^{\circ} \mathrm{C}, 30 \mathrm{MPa}\right)$ power plants with improved thermal efficiency are expected to make a significant contribution to the reduction in gas emission. Increasing the steam operating temperature and pressure will proportionally increase the plant efficiency with reduction in gas emission. Materials used in the power plant should withstand creep and steam oxidation, while increasing the steam operating temperatures. The featured material should possess both creep and steam oxidation resistance, along with ease of fabrication. Along with these requirements, modern steam turbine component experience damage caused by the impact of small solid particles entrained in the gas or liquid stream.

Solid particle erosion of steam path surfaces has been a major concern in thermal power plants. This is mainly due to the formation of magnetite, an oxide of iron, on the inside of steam generator-ferritic alloy tubes, headers and steam lines exposed to high steam temperature. This builds up to a certain level and after further operation, it cracks and spalls, being brittle in nature. This magnetite breaks into angular particles and erodes all components in the steam path. The erosion damages are the most severe in areas where steam velocities are the highest and are commonly seen at the inlet or where reheated steam reenters the blade path. Identification of erosion-prone areas of steam turbine blading depends upon the flow characteristics such as its separation, reattachment and boundary layer growth.

In the past, extensive studies of solid particle erosion have been made, mainly at room temperature. Many parameters are now known to influence erosion behavior. The velocity of impinging particles influences the erosion rate considerably. The impingement angle is another important factor, with the maximum erosion rate occurring for ductile materials at sharp impingement angles of about $20^{\circ}-30^{\circ}$ and for brittle materials at normal impingement. Particle properties such as size, hardness and shape and particle concentration are also influencing factors. The erosion rate, of course, depends on the target materials. Temperature may also be an influencing factor. Since particle-erosion is a function of other parameters such as particle size, concentration, impingement angle and hardness of base material, in most cases it can only be improved by providing a protective hard coating on the erosion-prone areas. 
Thermal sprayed cermet and metallic coatings are often used to resist severe wear in diverse industrial applications as mining, mineral or pulp and paper processing, aerospace and automobile manufacturing, and power generation. The ability of a coating to protect base materials against erosion depends upon its composition and microstructure, and its overall structural integrity. In turn, these are dependent on starting material composition and processing. Also, Ceramic coatings are widely used as wear resistant and insulating coatings. Atmosphere plasma spraying (APS) is a commonly used method for preparing these coatings. However, in traditional APS the powders are injected into the plasma flame outside of the nozzle, or powders are injected into the inside of the nozzle through a hole in the radius direction of the nozzle side. The porosity of these coatings deposited by APS is usually $5-10 \%$. Generally, these coatings appear to be chosen on the basis of their good high temperature oxidation resistance and are mainly alloys containing high quantities of nickel and/or chromium. Whilst it has been reported that uniformly deposited and coherent coatings can provide erosion protection, many of the factors which control the rate of erosion, such as particle velocity, number of particles impacting a surface and their angle of impingement can be largely determined by the flow conditions of the system.

The advent of high velocity oxygen-fuel (HVOF) thermal spray has made a significant impact on the field, producing dense, well-adhered and more homogenous deposits of metals and cermets, due mainly to the combination of higher kinetic energy and lower spray temperatures. The HVOF process is an enhancement of combustion spraying, in which, a compressed flame undergoes free expansion upon exiting the torch nozzle, thereby experiencing a dramatic gas acceleration. By axially injecting the feedstock powder, the particles are also subjected to a high acceleration to supersonic velocities. As a result, upon impacting the substrate, they spread out thinly to form a dense coating with low degrees of decomposition which are well bonded to the substrate. Also, owing to the high kinetic energy acquired by the powder particles, the process allows producing carbide based coatings and ensures a good cohesion with a minimum porosity and decarburization.

The present program involves a Design of experiments (DOE) approach to address the erosion and steam oxidation resistance for steam turbine components. The focus will be to utilize the potential of HVOF coating technology to deposit dense adherent coatings to meet the defined CTQs. The steps involve identification of materials compositions and evaluating the properties/performance of these coatings. Once the optimal coating performance is obtained, steps will be carried out to address the robustness of the process. 


\subsubsection{Testing and Validation:}

Siemens will conduct a comprehensive patent and literature search to identify metallic and ceramic materials, which provide the best combination of steam oxidation and erosion resistance. A Design of Experiments approach will be employed to evaluate the relevant coating properties and performance. Robust design approach will be carried out to define the process limits to achieve consistent coatings. The coatings will also be evaluated for microstructure/porosity characterization, erosion and steam oxidation performance. Also, compositions which exhibit improved performance will be subjected to detailed system performance evaluation. Long term performance studies will also be carried out.

\subsubsection{GO/NO GO Key Decision Points}

\begin{tabular}{|l|l|}
\hline Date & Decision to be Made \\
\hline 24 months & $\begin{array}{l}\text { Acceptable steam oxidation and erosion } \\
\text { performance of coating }\end{array}$ \\
\hline 48 Months & $\begin{array}{l}\text { Long term durability and process control } \\
\text { established }\end{array}$ \\
\hline
\end{tabular}

Key Milestones \& Deliverables (internal and external, both)

\begin{tabular}{|l|l|}
\hline Date & Deliverable \\
\hline 12 months & $\begin{array}{l}\text { Identify system requirements and material } \\
\text { compositions }\end{array}$ \\
\hline 18 months & $\begin{array}{l}\text { Establish process parameters for initial } \\
\text { screening }\end{array}$ \\
\hline 36 months & $\begin{array}{l}\text { Acceptable steam oxidation and erosion } \\
\text { performance of coating }\end{array}$ \\
\hline 48 months & $\begin{array}{l}\text { Down-select coating composition and } \\
\text { establish product robustness }\end{array}$ \\
\hline
\end{tabular}




\subsection{Casing materials / large scale nickel castings}

\subsubsection{Technical Barriers \& Research Approach:}

\begin{tabular}{|l|l|}
\hline $\begin{array}{l}\text { Technology \& Manufacturing Barriers \& } \\
\text { Risks }\end{array}$ & $\begin{array}{l}\text { Approach to Overcome the Technical } \\
\text { Issues/Barriers }\end{array}$ \\
\hline $\begin{array}{l}\text { Optimizing the casting process for large } \\
\text { castings }\end{array}$ & $\begin{array}{l}\text { Thermodynamic modeling and fluid flow } \\
\text { modeling }\end{array}$ \\
\hline Design optimized & $\begin{array}{l}\text { Interaction with Thermodynamic and fluid } \\
\text { flow modeling }\end{array}$ \\
\hline
\end{tabular}

\subsubsection{Benefit to Program:}

With the increased pressures and temperatures in a USC turbine, higher temperature casing alloys are required. To mitigate the cost of adoption of nickel-based alloys, the use of cooling may be employed along with TBC coatings. However, cooling reduces the engine efficiency and thus should be avoided f economically feasible.

The Thermie program in Europe looked at the use of IN 625 and IN 617 for castings, producing large scale sand castings in both alloys. It is considered that, with TBC coatings, these alloys will probably be sufficient for the even higher temperatures needed for the DOE specified turbines. Full characterization and alloy data generation is however needed, as the European programs only looked at demonstrating the feasibility of casting these alloys in large scale components.

\subsubsection{Testing and Validation:}

- Modeling of process for current alloys

- Concurrent optimization of casing design and casting process.

- Detailed microstructural analysis of castings to identify flow effects and inhomogeneity.

- Standard mechanical testing 


\subsubsection{GO/NO GO Key Decision Points}

\begin{tabular}{|l|l|}
\hline Date & Decision to be Made \\
\hline 6 months & $\begin{array}{l}\text { Economic analysis of alloy vs. cooling } \\
\text { choice }\end{array}$ \\
\hline 12 months & $\begin{array}{l}\text { Selection of alloy based on properties and } \\
\text { castability }\end{array}$ \\
\hline
\end{tabular}

\subsubsection{Key Milestones \& Deliverables (internal and external, both)}

\begin{tabular}{|l|l|}
\hline Date & Deliverable \\
\hline 6 months & Complete modeling of process \\
\hline 12 months & Full scale casting analysis \\
\hline 24 months & Completion of fatigue and tensile testing \\
\hline 30 months & Optimized casting design \\
\hline 48 months & $\begin{array}{l}\text { Second trial casting and microstructural } \\
\text { analysis }\end{array}$ \\
\hline 102 months & Mechanical data available for both alloys \\
\hline
\end{tabular}




\subsection{Bolting - high temperature bolt alloy}

\subsubsection{Technical Barriers \& Research Approach:}

\begin{tabular}{|l|l|}
\hline $\begin{array}{l}\text { Technology \& Manufacturing Barriers \& } \\
\text { Risks }\end{array}$ & $\begin{array}{l}\text { Approach to Overcome the Technical } \\
\text { Issues/Barriers }\end{array}$ \\
\hline Stress Corrosion resistance & $\begin{array}{l}\text { High Chromium alloy, rare earth alloying } \\
\text { additions }\end{array}$ \\
\hline & \\
\hline
\end{tabular}

\subsubsection{Benefit to Program:}

Currently alloys such as Refractaloy 26 and Nimonic $80 \mathrm{~A}$ are routinely used for bolting applications due to their combination of strength and corrosion resistance. For higher temperature turbines, these alloys will be pushed up to and beyond their limits.

In the last 2 years two new wrought superalloys (see table below) have been developed. Inconel 740, which was specifically developed for high corrosion resistance at temperatures around $700^{\circ} \mathrm{C}$. Haynes 282 has reported creep strength exceeding that of the forged blade alloy Waspaloy, but still retains high low temperature ductility. These and other more conventional alloys such as IN 617, Haynes 230 and Haynes HR120 all have mechanical properties which significantly exceed those of Refractalloy 26 due to the absence of iron in their compositions. All have as much or more chromium as well, and thus are likely to have sufficient corrosion resistance. The other critical property is notch strength. To select an alloy for this application, the notch strength of candidate alloys must be determined, both for creep and tensile notch sensitivity. Conventional smooth testing on the newest alloys (IN 740 and Haynes 282) is proposed in other subtasks, and thus will not be addressed here.

Table 5. Composition of high temperature wrought alloys

\begin{tabular}{|c|c|c|c|c|c|c|c|c|c|c|c|c|c|c|c|}
\hline Alloy & $\mathrm{Ni}$ & $\mathrm{Cr}$ & Co & Mo & $\mathrm{Al}$ & C & $\mathrm{Fe}$ & $\mathrm{Mn}$ & $\mathrm{Si}$ & $\mathrm{Ti}$ & $\mathrm{Cu}$ & $B$ & $\mathrm{Nb} \mathrm{V}$ & W & $\mathrm{La}$ \\
\hline IN 617 & $44.5^{m}$ & $20-24$ & $10-15$ & $8-10$ & $0.8-1.5$ & $.05-.15$ & $3^{*}$ & $1^{*}$ & $1^{*}$ & $0.015^{*} 0.6^{*}$ & $0.5^{*}$ & .006 * & & & \\
\hline IN 740 & $48^{\mathrm{a}}$ & 25 & 20 & 0.5 & 0.9 & 0.03 & 0.7 & 0.3 & 0.5 & 1.8 & & & 2 & & \\
\hline Haynes 282 & $57^{a}$ & 19.5 & 10 & 8.5 & 1.5 & 0.06 & $1.5^{*}$ & $0.3^{*}$ & $0.15^{*}$ & 2.1 & & 0.01 & & & \\
\hline Haynes 230 & $57^{a}$ & 22 & $5^{*}$ & 2 & 0.3 & 0.1 & $3^{*}$ & 0.5 & 0.4 & & & $.015^{*}$ & & 14 & 0.02 \\
\hline Hastelloy X & $47^{a}$ & 22 & 1.5 & 9 & & 0.1 & 18 & $1^{*}$ & $1^{*}$ & & & $.008^{*}$ & & 0.6 & \\
\hline
\end{tabular}




\subsubsection{Testing and Validation:}

Screening Tests

\begin{tabular}{|l|l|}
\hline Test Type & Parameters \\
\hline Notch Tensile & $700^{\circ} \mathrm{C}$ \\
\hline Notch Creep & $700^{\circ} \mathrm{C}, 1000 \mathrm{hrs}$ \\
\hline Corrosion notch creep & $700^{\circ} \mathrm{C}, 1000 \mathrm{hrs}$ \\
\hline
\end{tabular}

Tensile, fatigue, creep testing of selected alloys

\begin{tabular}{|l|l|l|}
\hline Test Type & Temperature & Details / Comments \\
\hline Notched Tensile & RT to $800^{\circ} \mathrm{C}$ & 3 of each \\
\hline Notched Creep & 600 to $800^{\circ} \mathrm{C}$ & To $300,1000,3000$ hrs for rupture \\
\hline Notched LCF & RT to 800 & To $300,1000,3000,10000$ cycles \\
\hline
\end{tabular}

Stress Corrosion Trials

\begin{tabular}{|l|l|}
\hline Temperature & Time \\
\hline 600 to $800^{\circ} \mathrm{C}$ & $1,10,30,100,300,1000,3000,10 \mathrm{k}$ hrs \\
\hline
\end{tabular}

\subsubsection{Interdependencies:}

\begin{tabular}{|l|l|}
\hline Milestone/Deliverable in this subtask (Output) & Dependent Subtask (Input) \\
\hline Design Requirements for Alloy and Welds & Design \\
\hline
\end{tabular}




\subsubsection{GO/NO GO Key Decision Points}

\begin{tabular}{|l|l|}
\hline Date & Decision to be Made \\
\hline 18 months & $\begin{array}{l}\text { Are the alloys sufficiently better (if at all) } \\
\text { than the currently used materials. }\end{array}$ \\
\hline
\end{tabular}

11.9.6 Key Milestones \& Deliverables (internal and external, both)

\begin{tabular}{|l|l|}
\hline Date & Deliverable \\
\hline 18 months from start & Initial report of mechanical behavior \\
\hline 24 months & Corrosion trial results. Alloy selection \\
\hline 36 months & $\begin{array}{l}\text { Mechanical data for selected alloys in } \\
\text { design database. Manufacturing process } \\
\text { defined }\end{array}$ \\
\hline
\end{tabular}




\subsection{High strength pipe materials}

\subsubsection{Technical Barriers \& Research Approach:}

\begin{tabular}{|l|l|}
\hline $\begin{array}{l}\text { Technology \& Manufacturing Barriers \& } \\
\text { Risks }\end{array}$ & $\begin{array}{l}\text { Approach to Overcome the Technical } \\
\text { Issues/Barriers }\end{array}$ \\
\hline $\begin{array}{l}\text { Weldability and formability insufficient for } \\
\text { purpose }\end{array}$ & Modify alloy composition. \\
\hline
\end{tabular}

\subsubsection{Benefit to Program}

Currently, IN 617, Hasteloy X and Haynes 230 are routinely used in applications where high temperature strength and formability are required. As turbine temperatures and pressures rise, these materials require increased cooling to retain sufficient strength for their mechanical tasks. The USC turbine will increase the firing temperature by more than $150^{\circ} \mathrm{C}$ over today's production engines, combined with a gas pressure of 300 bar as compared with today's 150 bar. Whilst use of TBC technology can mitigate the temperature increases that the components see, the increases that will occur, combined with the increased loadings from both the higher temperatures and the increased sizes, probably require higher strength combustor materials. This is of particular concern in the area of piping.

In the last 2 years two new wrought superalloys (see table below) have been developed. Inconel 740 , which was specifically developed for high corrosion resistance at temperatures around $700^{\circ} \mathrm{C}$, is a promising candidate for use in high pressure piping (to be tested for 1.5.8.1 Materials for ITM). Haynes 282 has reported creep strength exceeding that of the forged blade alloy Waspaloy, but still retains high low temperature ductility. This allows the forming of large complex sheet structures such as transition ducts and combustor cans as well as pipes, whilst permitting increased operating temperatures. The mechanical strength of the alloy (according to vendor literature) is approximately $100^{\circ} \mathrm{C}$ higher than Inconel 617 , which enables significant component uprates without increasing the cooling required. 


\subsubsection{Testing and Validation:}

Standard tensile, fatigue, creep testing of Haynes 282, HR120 and Inconel 740.

\begin{tabular}{|l|l|l|}
\hline Test Type & Temperature & Details / Comments \\
\hline Tensile & RT to $1000^{\circ} \mathrm{C}$ & 3 of each \\
\hline Creep & 600 to $1000^{\circ} \mathrm{C}$ & To $300,1000,3000$ hrs for rupture \\
\hline LCF & RT to $1000^{\circ} \mathrm{C}$ & To $300,1000,3000,10000$ cycles \\
\hline
\end{tabular}

Corrosion position testing on IN 740 (against current pipework alloys).

Cyclic oxidation testing in steam.

\begin{tabular}{|l|l|}
\hline Temperature & $\begin{array}{l}\text { Weight measurement times } \\
\text { (approximate) }\end{array}$ \\
\hline $650^{\circ} \mathrm{C}$ to $800^{\circ} \mathrm{C}$ & $0,1,3,10,30,100,300,1000$ \\
\hline
\end{tabular}

\subsubsection{Interdependencies:}

\begin{tabular}{|l|l|}
\hline Milestone/Deliverable in this subtask (Output) & Dependent Subtask (Input) \\
\hline Design Requirements for Alloy and Welds & Design \\
\hline
\end{tabular}

\subsubsection{GO/NO GO Key Decision Points}

\begin{tabular}{|l|l|}
\hline Date & Decision to be Made \\
\hline 18 months & $\begin{array}{l}\text { Are the alloys sufficiently better (if at all) } \\
\text { than the currently used materials. }\end{array}$ \\
\hline 24 months & $\begin{array}{l}\text { Coating trials - are coating spalation rates } \\
\text { sufficiently low to allow TBC coating of the } \\
\text { H282 alloy if needed }\end{array}$ \\
\hline
\end{tabular}




\subsubsection{Key Milestones \& Deliverables (internal and external, both)}

\begin{tabular}{|l|l|}
\hline Date & Deliverable \\
\hline 18 months from start & Initial report of mechanical behavior \\
\hline 24 months & Coating trial results \\
\hline 36 months & $\begin{array}{l}\text { Mechanical data for joints in MVision. } \\
\text { Manufacturing process defined }\end{array}$ \\
\hline
\end{tabular}




\subsection{Auxiliary \& Casing materials manufacture - welding development for Haynes 282}

\subsubsection{Introduction}

Material requirements are high temperature $\left(900^{\circ} \mathrm{C}\right)$, high pressure (30 bar) work environment with good material longevity. Typical high temperature materials include alloys R-41, Hasteloy X, Waspaloy, 625, 263, 230, 617, 120 and 188. Haynes 282 is a new high temperature superalloy developed to have improved resistance to strain age cracking in comparison to other gamma prime strengthened alloys. Strain age cracking, weldability, creep, oxidation control and cost are key factors in material selection.

\subsubsection{Technical Barriers \& Research Approach:}

\begin{tabular}{|l|l|}
\hline $\begin{array}{l}\text { Technology \& Manufacturing Barriers \& } \\
\text { Risks }\end{array}$ & $\begin{array}{l}\text { Approach to Overcome the Technical } \\
\text { Issues/Barriers }\end{array}$ \\
\hline $\begin{array}{l}\text { New alloy (October 2005) with limited data } \\
\text { availability }\end{array}$ & Fatigue testing \\
\hline Weldability & $\begin{array}{l}\text { Varestraint testing } \\
\text { Design of experiments } \\
\end{array}$ \\
& Destructive and nondestructive testing \\
\hline
\end{tabular}

\subsubsection{Benefit to Program:}

The alloy, Haynes 282, is to be evaluated for mechanical performance and formability in a separate program. It is intended for both combustor and auxiliary piping applications. In the turbine and related pipework, temperatures of $760^{\circ} \mathrm{C}$ are expected, which would require a high temperature material. Increasing the strength would allow us to reduce the pipe wall diameter and consequently reduce the cost and weight of the piping. Inherent in the use of the alloy for piping is the need to weld pipe sections. This project is designed to develop a weld process for the alloy.

Haynes 282 is an age hardenable alloy which forms gamma prime precipitates $\left(\mathrm{Ni}_{3} \mathrm{Al}\right.$ and $\mathrm{Ni}_{3} \mathrm{Ti}$ ). These precipitates are a strengthening mechanism and also a major factor for weldability. As illustrated Figure 33, welding difficulty increases from the lower left hand corner of the graph over the critical line into the less desirable welding region. 
Weldability per Al-Ti content

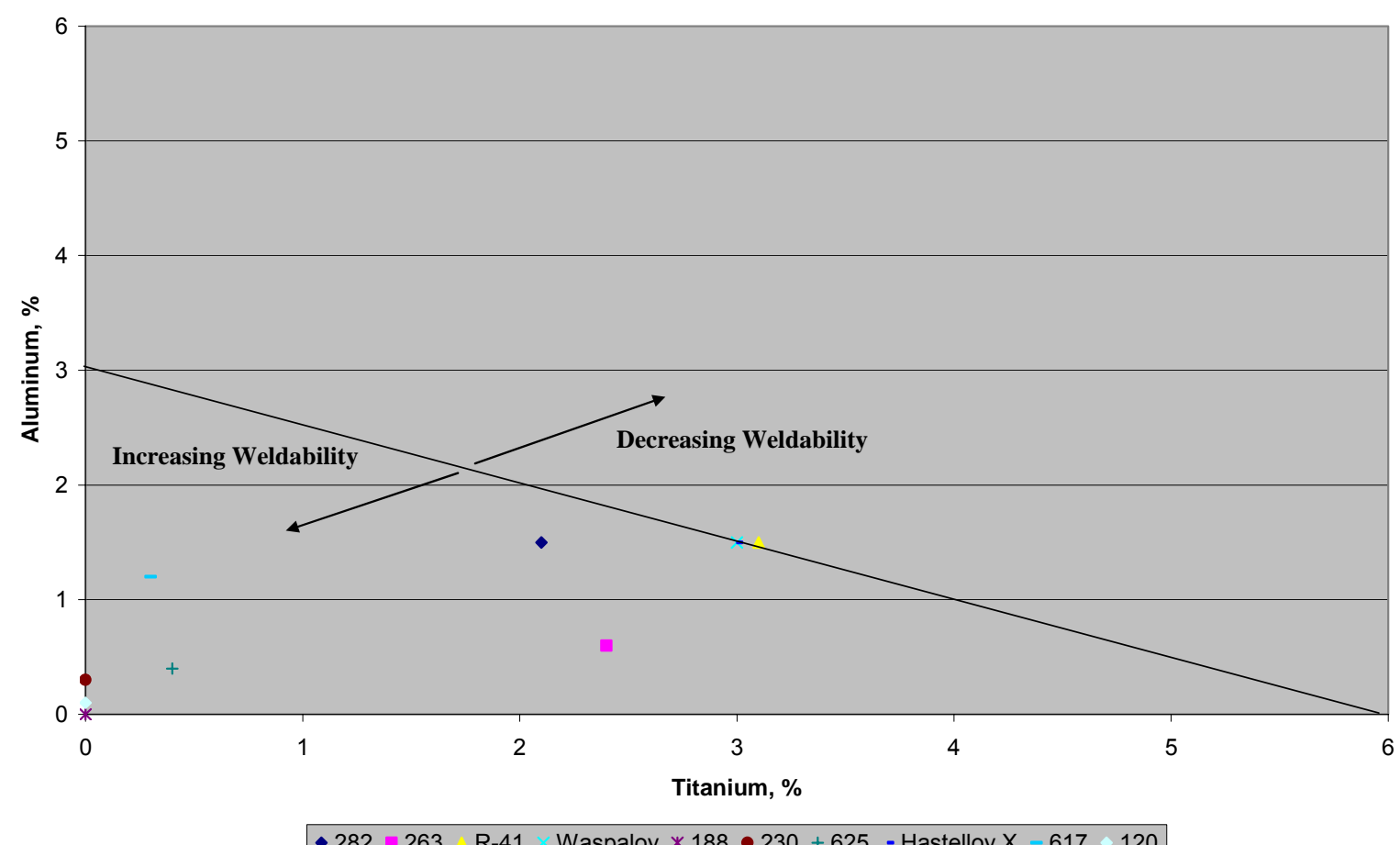

Figure 33. Weldability per Al-Ti content

Weldability increases from R-41 and Hasteloy X to alloys 230 and 188 . Haynes 282 rates at medium difficulty. Alloys 188 and 230 contain approximately 39 weight percent and 5 weight percent cobalt, respectively. Alloy 188 contains no Ti or Al, while 230 contains 0.3 weight percent Al. The vast presence of cobalt per alloy 188 significantly increases the cost.

To further compare the performance of the alloys, refer to Table 1 which compares the stress to rupture at a temperature of $871^{\circ} \mathrm{C}\left(1600^{\circ} \mathrm{F}\right)$ in 1000 hours. The top three alloys in Table 1 are (1) alloy 282 which has limited material and welding data, reasonable cost and medium welding difficulty (2) R-41 corresponds to low weldability rating and good cost effectiveness and (3) alloy 188 associates with high cost and favorable weldability. 
Table 6. Stress to produce rupture, based in literature data $\left(871^{\circ} \mathrm{C}\left(1600^{\circ} \mathrm{F}\right)\right.$ and 1000 hours).

\begin{tabular}{|l|l|}
\hline Alloy & Rupture stress, MPa \\
\hline Haynes 282 & 90 \\
Hené 41 & 90 \\
Inconel 617 & 67 \\
Haynes 230 & 66 \\
Haynes 120 & 59 \\
Inconel 625 & 52 \\
Waspaloy & 48 \\
C263 & 48 \\
Hasteloy X & 43 \\
304SS & 21 \\
\hline
\end{tabular}

Other material constraints surround material longevity. In the service environment, oxidation is a concern. When a metal oxide is produced, the metal used in creating the metal oxide is removed from the overall strength of the base material and considered metal loss. For a test length of 1008 hours and $982^{\circ} \mathrm{C}\left(1800^{\circ} \mathrm{F}\right)$ test temperature in flowing air, alloy 282 is among the forerunners in resistance to oxidation metal loss. Refer to Table 7. 
Table 7. Oxidation resistance

\begin{tabular}{|l|l|}
\hline Alloy & $\begin{array}{l}\text { Metal loss, } \\
\text { microns }\end{array}$ \\
\hline 282 & 5.08 \\
R-41 & 5.08 \\
120 & 5.08 \\
230 & 7.62 \\
625 & 7.62 \\
Hasteloy X & 7.62 \\
Waspaloy & 22.86 \\
263 & 27.94 \\
304 & 139.7 \\
\hline
\end{tabular}

Creep results from long term exposure to levels of stress that are below the yield or ultimate strength in combination with temperatures near the melting point of the material. The material deformation correlates to the material properties, stress and the exposure time and temperature. Creep is not always a failure mode. Creep resistance for alloy 282 is favorable in comparison to other high temperature alloys. See Table 8 for the approximate initial stresses (MPa) to produce $1 \%$ creep. for the approximate initial stresses $(\mathrm{MPa})$ to produce $1 \%$ creep. 
Table 8. Creep properties

\begin{tabular}{|c|c|c|c|c|}
\hline \multirow[b]{2}{*}{ Alloy } & \multirow[b]{2}{*}{ Test $\mathrm{T},{ }^{\circ} \mathrm{C} /{ }^{\circ} \mathrm{F}$} & \multicolumn{3}{|c|}{ Initial stress, MPa } \\
\hline & & 100 hours & 1000 hours & 10,000 hours \\
\hline 282 & $\begin{array}{l}871 / 1600 \\
923 / 1700\end{array}$ & $\begin{array}{l}124 \\
62\end{array}$ & $\begin{array}{l}69 \\
34\end{array}$ & $\begin{array}{l}- \\
-\end{array}$ \\
\hline 188 & $\begin{array}{l}871 / 1600 \\
923 \text { / } 1700\end{array}$ & $\begin{array}{l}62 \\
41\end{array}$ & $\begin{array}{l}44 \\
28\end{array}$ & $\begin{array}{l}- \\
-\end{array}$ \\
\hline 230 & $\begin{array}{l}871 \text { / } 1600 \\
923 \text { / } 1700\end{array}$ & $\begin{array}{l}62 \\
43\end{array}$ & $\begin{array}{l}41 \\
28\end{array}$ & $\begin{array}{l}30 \\
18\end{array}$ \\
\hline 263 & $\begin{array}{l}871 / 1600 \\
923 \text { / } 1700\end{array}$ & $\begin{array}{l}70 \\
-\end{array}$ & $\begin{array}{l}- \\
-\end{array}$ & $\begin{array}{l}- \\
-\end{array}$ \\
\hline 625 & $\begin{array}{l}871 / 1600 \\
923 \text { / } 1700\end{array}$ & $\begin{array}{l}24 \\
12\end{array}$ & $\begin{array}{l}12 \\
-\end{array}$ & - \\
\hline Hasteloy X & $\begin{array}{l}871 / 1600 \\
923 \text { / } 1700\end{array}$ & $\begin{array}{l}42 \\
-\end{array}$ & $\begin{array}{l}25 \\
-\end{array}$ & $\begin{array}{l}21 \\
-\end{array}$ \\
\hline 120 & $\begin{array}{l}871 / 1600 \\
923 / 1700\end{array}$ & $\begin{array}{l}76 \\
54\end{array}$ & $\begin{array}{l}55 \\
37\end{array}$ & $\begin{array}{l}35 \\
26\end{array}$ \\
\hline Waspaloy & $\begin{array}{l}871 / 1600 \\
923 \text { / } 1700\end{array}$ & $\begin{array}{l}124 \\
66\end{array}$ & $\begin{array}{l}68 \\
-\end{array}$ & $\begin{array}{l}- \\
-\end{array}$ \\
\hline
\end{tabular}

The preliminary data for Haynes 282 appears to be a good material selection for this application; however, additional material and weld testing need to be completed.

\subsubsection{Testing and Validation:}

- Varestraint test(s) - material sensitivity to cracking

- Design of experiments - characterization of material operating region(s)

- Nondestructive and destructive test(s) - evaluation of microstructure and defect(s); analysis of weldment properties in comparison to operating parameters 


\subsubsection{Interdependencies:}

\begin{tabular}{|l|l|}
\hline Milestone/Deliverable in this subtask (Output) & Dependent Subtask (Input) \\
\hline Weldability of selected alloys & \\
\hline
\end{tabular}

\subsubsection{GO/NO GO Key Decision Points}

\begin{tabular}{|l|l|}
\hline Date & Decision to be Made \\
\hline 11 months & $\begin{array}{l}\text { Based on preliminary data, which alloy(s) } \\
\text { are less susceptible to cracking? }\end{array}$ \\
\hline
\end{tabular}

11.11.7 Key Milestones \& Deliverables (internal and external, both)

\begin{tabular}{|l|l|}
\hline Date & Deliverable \\
\hline 5 months & Samples fabricated for welding \\
\hline 11 months & Varestraint testing complete \\
\hline 23 months & Vender weld qualification \\
\hline 28 months & $\begin{array}{l}\text { Destructive/nondestructive testing } \\
\text { complete }\end{array}$ \\
\hline 36 months & Design data complete \\
\hline
\end{tabular}




\section{CONCLUSIONS}

To allow the design of $760^{\circ} \mathrm{C}$ capable steam turbines without component cooling, a very large leap in material capability is required. Ferritic materials are unlikely to be suitable for temperatures beyond $650^{\circ} \mathrm{C}$ within the foreseeable future. The new generation of nano-strengthened alloys provides significant improvements in strength beyond that of traditional tempered martensitic steels, but currently suffers from significant drawbacks when used at higher temperatures. For the lower $\mathrm{Cr}$ level steels $(9 \%)$ the alloy microstructure appears relatively stable beyond $600^{\circ} \mathrm{C}$, but the oxidation resistance is insufficient. In contrast, the $12 \% \mathrm{Cr}$ steels have better oxidation resistance, but do not appear to be stable for long periods of exposure. Consequently, for the near-term, for the higher temperature regions, nickel-based superalloys will be needed.

The work carried out on the CF8C+ alloy (a nano-strengthened variant of conventional 347SS) shows significant improvements in terms of creep capability. This demonstrates that the potential does exist to push steels to higher temperatures, possibly with the help of oxidation coatings. However, due to the stability questions mentioned above, extensive long term testing of such alloys will be required before they can be implemented.

For blading, current gas turbine alloys will be suitable. With advanced processing, current turbine disk materials will probably be suitable for the first stage of the rotor. For stages further back, large forgings are likely to be realistic. The rotor will have to be a composite structure, probably welded, to reduce the cost to a reasonable level.

Erosion-resistant coatings suitable for the highest temperatures have not been tested, but compositions are available which are likely to be suitable for the application. Testing of these coatings is currently being funded by the DOE in another program.

The largest issue will be with the cast components such as casings and valve bodies. Current superalloys have sufficient strength, but have not been cast in such large sizes under sand-cast conditions. Roadmaps of the expected development time are provided, which indicated that the materials required can be available within a 5 year time span, i.e. 2011 at the time of writing. 


\section{ACKNOWLEDGEMENTS}

Siemens would like to thank Professor Koch from North Carolina State University for input into this review and John Haas from Metaltek International for the provision of casting of the CF8C+Alloy. 


\section{References}

${ }^{1}$ T.-U. Kern, K.Wieghardt and H. Kirchner, "Materials and design solutions for advanced steam power plants“, 4th Int. Conf. Advances in Materials Technology for Fossil Power Plants, Hilton Head, SC (2004)

${ }^{2}$ H. Danielssen and J. Hald, "Z-Phase in 9-12\% Cr Steels", , 4th Int. Conf. Advances in Materials Technology for Fossil Power Plants, Hilton Head, SC (2004)

${ }^{3} \mathrm{~F}$. Abe, "Alloy design of creep and oxidation resistant $9 \mathrm{Cr}$ steels for thick section boiler components", , 4th Int. Conf. Advances in Materials Technology for Fossil Power Plants, Hilton Head, SC (2004)

${ }^{4}$ H. Danielssen and J. Hald, "Z-Phase in 9-12\% Cr Steels" , 4th Int. Conf. Advances in Materials Technology for Fossil Power Plants, Hilton Head, SC (2004)

${ }^{5}$ K. Haarmann et al, "The T91 / P91 Book", Vallourelec Mannesmann Tubes (2002)

${ }^{6}$ B. Scarlin and T-U Kern, "The European Efforts in Materials Development for $650^{\circ} \mathrm{C}$ USC Power Plants - COST522".

${ }^{7}$ T. Uehara et al in Materials for Advanced Power Engineering, Liege 2002, pp 1311-1320

${ }^{8}$ E. Schnabel et al, Stahl und Eisen, 107, 1987, pp691-696

${ }^{9}$ B. Scarlin et al, "Materials developments for ultra supercritical steam turbines", 4th Int. Conf. Advances in Materials Technology for Fossil Power Plants, Hilton Head, SC (2004)

${ }^{10}$ P.J. Ennis, "Creep strengthening mechanisms in 9-12\% chromium steels", 4th Int. Conf. Advances in Materials Technology for Fossil Power Plants, Hilton Head, SC (2004)

${ }^{11} \mathrm{H}$. Semba, F.Abe "Creep deformation behavior and microstructure in high boron containing $9 \% \mathrm{Cr}$ ferritic heat resistant steel” , 4th Int. Conf. Advances in Materials Technology for Fossil Power Plants, Hilton Head, SC (2004)

${ }^{12}$ Crucible Compaction Metals

${ }^{13}$ P. W. Keefe, S. 0. Mancuso \& G. E. Maurer, "Effects of Heat Treatment and Chemistry on the Long-Term Phase Stability of a High Strength Nickel-Based Superalloy", Superalloys 1992, Ed. S.D. Antolovich et al, pp487-496, TMMS,1992 